Article

\title{
On the Interpretation of Watercraft in Ancient Art
}

\author{
Shelley Wachsmann ${ }^{1,2}$ \\ 1 Nautical Archaeology Program, Department of Anthropology, Texas A\&M University, College Station, \\ TX 77843-4352, USA; swachsmann@tamu.edu \\ 2 Institute of Nautical Archaeology, PO Drawer HG, College Station, TX 77841-5137, USA
}

Received: 21 August 2019; Accepted: 12 November 2019; Published: 11 December 2019

\begin{abstract}
In the past six decades since its inception, nautical archaeologists have excavated and studied the hulls, cargoes, and other remains of ancient watercraft. However, shipwrecks themselves only tell part of the story. The archaeological record is replete with examples of known shipwrecks from some cultures and periods, but, for others, no hulls exist in the known archaeological record. Vagaries of preservation generally prevent the upper parts and rigging of a vessel to survive in all but the most remarkable of cases. This paper reviews the role of iconographic representations in understanding ancient vessels and seafaring by presenting the issues, examining the limitations, proposing interpretative methods for, and finally by supplying specific examples of, ancient nautical depictions.
\end{abstract}

Keywords: art history; Egyptian art; graffiti; Minoan art; Mycenaean art; nautical archaeology; ship iconography

Until we excavate a sunken ancient vessel lying upside down on the sea bed, preserving in sand or mud most of the deck, we have to rely for our knowledge of the latter on vase painters, artists' representations and more surely on graffiti by sailors.

Thurneyssen (1979)

\section{Introduction: Why Iconography?}

Throughout human existence, watercraft have been among the most complex artifacts created by any culture (Muckelroy 1978, p. 3; J. Richard Steffy pers. comm.). Even today, space craft-space ships - arguably fit this description. We cannot imagine a past in which vessels did not play a crucial role in exploration, migration, trade, and war at one time or another. Virtually everything ever made or used by humans has been transported by ship, up to and including the pyramids of Egypt, whose brilliant white limestone casing had to be shipped across the Nile, in block form, from the Tura quarries on the river's east bank (Grimal 1992, pp. 27, 109, 111 figure 5, 113, 177). Evidence for seafaring might go as far back as the Lower Paleolithic circa 200,000 years ago (Carter et al. 2019; Strasser et al. 2010). Yet, until the introduction of SCUBA in the midst of World War II, our knowledge of ancient vessels themselves remained limited.

Archaeologists have discovered (often with the help of non-archaeologists), excavated, studied, and published numerous shipwrecks from across the Seven Seas writ large since the first scientific underwater nautical excavation in 1960, led by George F. Bass (1967) on the Cape Gelidonya shipwreck (circa 1200 BC, Turkey). ${ }^{1}$ Nautical archaeology has contributed immeasurably to an understanding of our collective maritime past. Additionally, thanks to the sub-discipline of hull reconstruction, which

1 On the early days of nautical archaeology, see (Bass 1976). For relevant nautical vocabulary, see below, Appendix A: Glossary of Nautical Terms. 
was first defined by J. Richard 'Dick' Steffy (1994), experts now can study even minimal hull remains and reconstruct much of a vessel's missing parts.

Despite this cornucopia of information, ancient shipwrecks can only tell part of their own stories. While there exist numerous shipwrecks, many of which are well documented, from some historical epochs-Roman, Byzantine, and medieval, for example-there remain other cultures/periods (the Minoans, the Mycenaeans, and the Sea Peoples, etc.) for which no hulls have been reported to date. ${ }^{2}$

Furthermore, less information normally survives pertaining to the upper parts of ships than for their lower hulls and contents due to the vagaries of wooden-planked hulls' preservation after their deposition on the seabed. During or after storms and battles, masts, sails, and rigging may have been lost or intentionally cut away (Acts 27:19). Vessels that went down in deep water will consistently land upright on the seabed, irrespective of the manner in which they disappeared below the waves (Robert D. Ballard, pers. comm.; Ballard et al. 2000, p. 1616; Kloner and Wachsmann 1978, pp. 131-33; Wachsmann 2011a, p. 206). This phenomenon also holds true for the vast majority of vessels that sank near coastal obstructions, an estimated 80 percent of all ship losses (Bascom 1976, p. 84). Indeed, only in rare cases, when vessels end their days inverted, do the upper parts of ancient wooden-planked ships survive (Herculaneum Boat [AD 79]: Steffy 1985; Steffy 1994, pp. 67, 69 figure 3-56, 71; Pisa D shipwreck [Late Antiquity]: Bruni and Abbado 2000, pp. 48-51, 68, figures 38-40; Camilli and Setari 2005, pp. 76-77; Port Berteau II shipwrecks [7th-century AD]: Rieth 2016, pp. 284 figure 164, 285 figure 165, 286 figure 166, 287-288, 289 figure 167, 290). Ancient Mediterranean shipwrecks normally reveal themselves through exposed inorganic artifacts, usually amphorae. Organic materials unprotected by sediment disappear over time due to waterlogging, which results in the leaching out of water-soluble elements (organic acids, starches, and sugars). This, together with the destruction that is carried out by a variety of wood-eating boring mollusks, bacteria, and, to a lesser degree, fungi, eventually consumes all traces of exposed timbers and other organic materials (Figures 1 and 2a) (Kohlmeyer 1969; Wessel 1969; Grattan 1987; Herdendorf et al. 1995, pp. 80-82). On average, only about ten percent of wooden-planked hulls original structure survives (Steffy 1994, p. 6). In the vicinity of the Mediterranean, the Black Sea alone allows for the survival of ancient ships' timbers in the water column due to the unusual chemistry of its anoxic and toxic lower depths (Bascom 1976, pp. 36, 37 figure 7, 38; Ballard 2001, pp. 54-61; Brennan et al. 2013; Broad 2016).

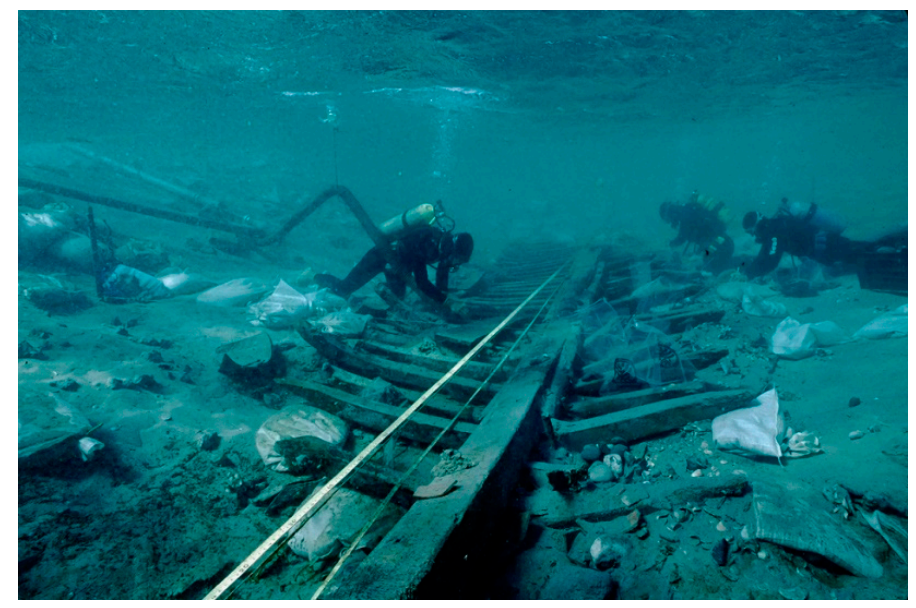

Figure 1. The Tantura B shipwreck is typical of the preservation of wooden-planked shipwrecks in the Mediterranean Sea, with only the lower parts of the hull, which had been buried in sediment soon after deposition, surviving. Early ninth-century AD, Tantura Lagoon, Israel. Photo: S. Wachsmann.

2 One hopes that the recent discovery of a cargo of what appear to be pillow-shaped copper (oxhide?) ingots in the region of Kumluca, Turkey, might indicate a Minoan shipwreck with surviving hull remains (Oniz 2019). 


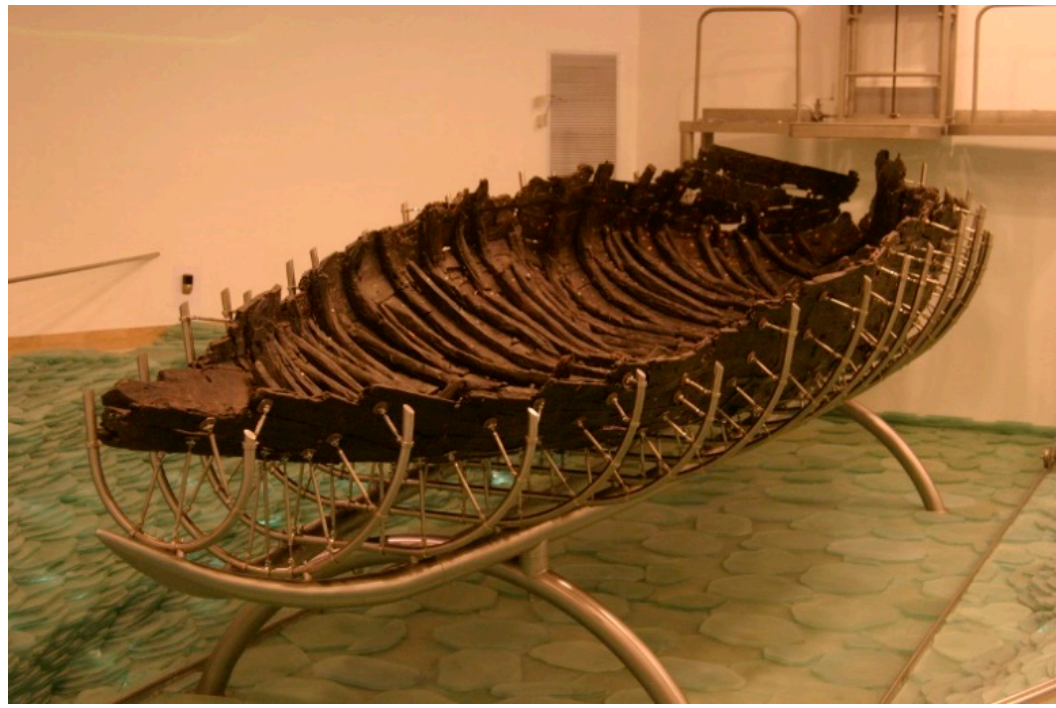

(a)

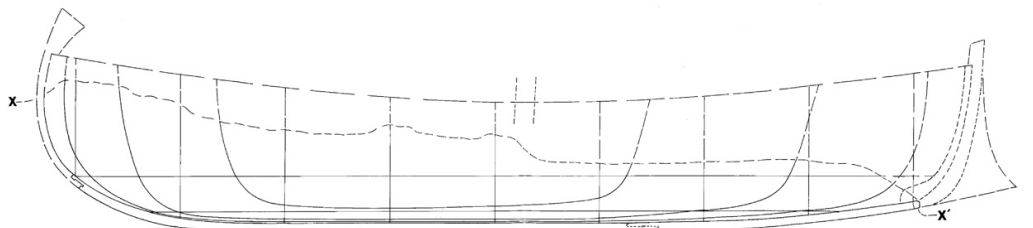

(b)

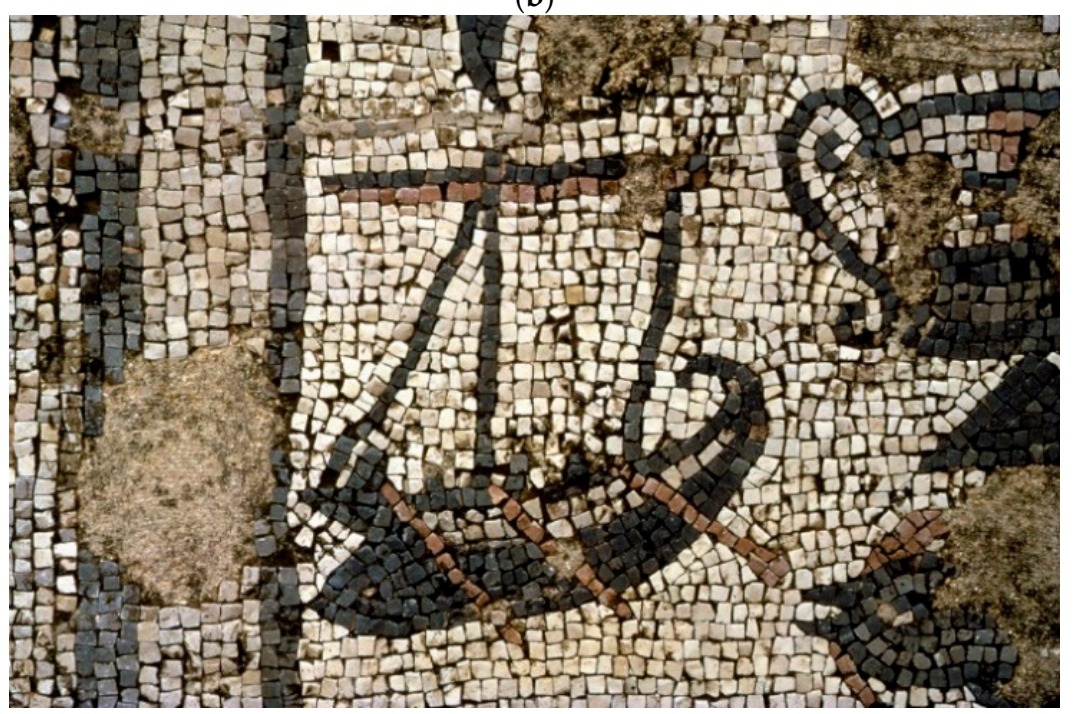

(c)

Figure 2. (a) The Kinneret Boat. Bow facing left.; (b) Starboard sheer plan from J. Richard Steffy's lines drawings. Note Steffy's reconstruction of the missing bow with a cutwater at right and the recurving stern. Dashed line $X-X^{\prime}$ represents the height of preservation of the hull's starboard side; (c) The boat mosaic found at the adjacent site of Migdal. (First-century AD). (a) Photo: S. Wachsmann. (b) from Steffy 1990, foldout 2. (c) Photo: D. Syon. Courtesy of the Yigal Alon Museum. Used by permission.

The loss of much of the information regarding the upper portions of ancient shipwrecks is a limiting factor in what can be learned regarding the overall appearance of ancient ships solely from shipwreck archaeology. Thus, there remains a significant role for the study of contemporaneous iconography, even with the advent of the scientific excavations of shipwrecks. As Christopher Monroe $(2009$, p. 90) notes in regard to Egyptian ship representations, shipwrecks and nautical imagery supplement each other in a remarkable manner: 
Because only the lower portions of Bronze Age hulls have been preserved, these Egyptian models and pictures are the most reliable guide for reconstructing the mast and yards, rigging, steering, and other parts of the ship that are not completely buried, and thereby preserved, at the time of wrecking.... By sheer coincidence, the preserved hulls and iconography are perfect complements, since the pictures never indicate what is below the water line.

This finds expression, for example, in the artist's reconstruction of the Uluburun shipwreck (circa 1300 BC, Turkey) that appears in a National Geographic Magazine article authored by Bass (1987, pp. 694-96) (Figure 3). The positioning of the vessel's cargo in the hold derives from an understanding of the excavation evidence, while the upper parts of the ship replicate Syro-Canaanite ships from the Theban tomb of Kenamun (Theban Tomb [henceforth TT] 162; Amenhotep III) (Figures 4 and 5). ${ }^{3}$

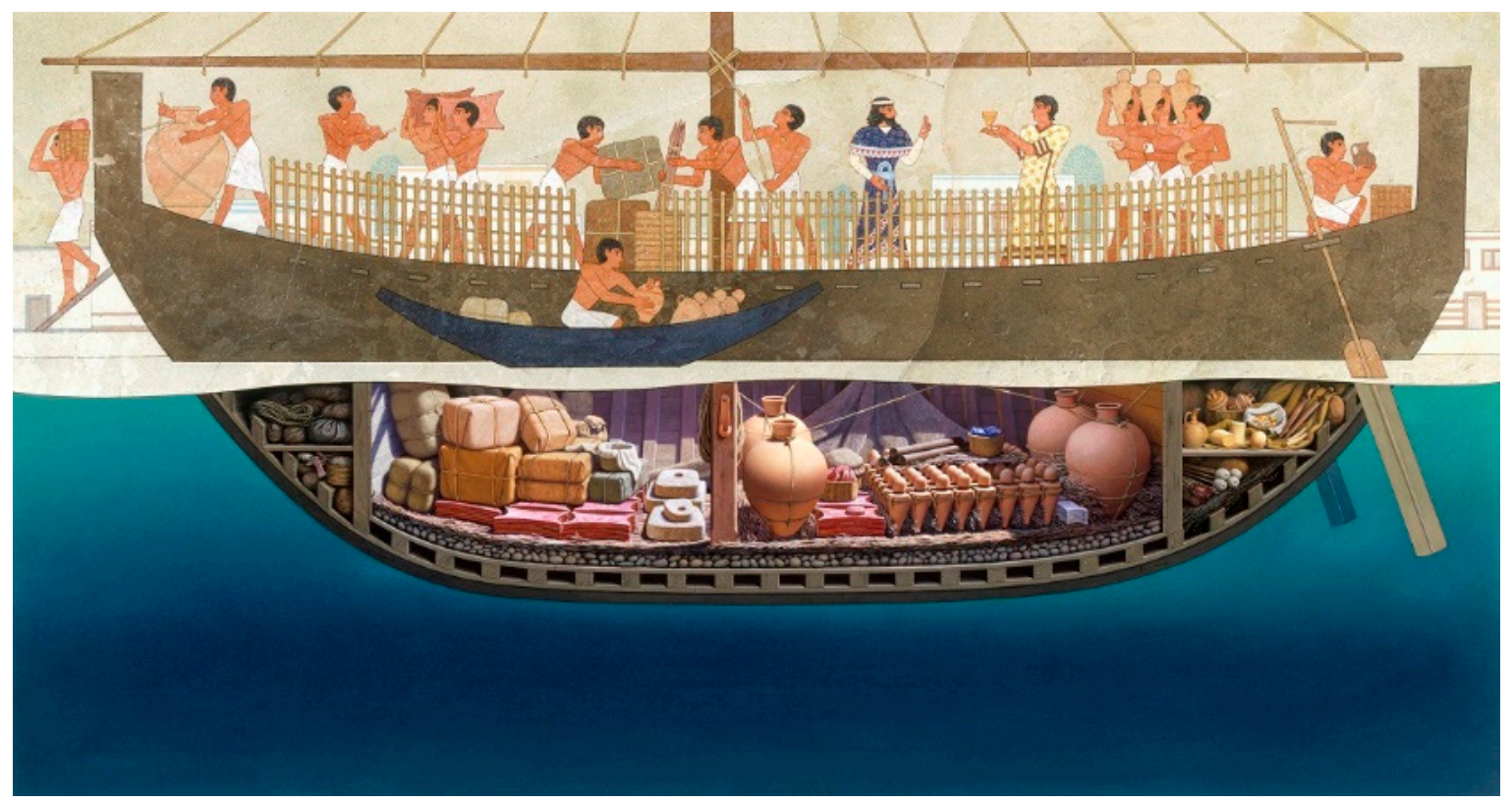

Figure 3. National Geographic reconstruction of the Uluburun shipwreck. Artist: Rosalie Seidler. Courtesy National Geographic Image Collection.

To utilize ancient images, we must understand their intrinsic character. What Norman de Garis Davies (1930, pp. 29-30), the great chronicler of Theban tombs, notes in regard to interpreting their art also holds true for ancient ship iconography:

If the study of written documents and that of excavated objects have their special difficulties and limitations, the interpretation of pictured records, forming a third division of historical research, also offers scope for philological and archaeological knowledge, as well as wide experience and some psychological sense. We may ask then what measure of truth can be reached in this third field, and particularly in that realm which is just now claiming special attention-the precise valuation of such scenes as illuminate the international relations of Egypt in the imperial period.

3 I use the term 'Syro-Canaanite' here to denote the cultural entities that inhabited the shores of the eastern Mediterranean, from the Bay of Iskenderun in the north to the shores of Sinai in the south during the Middle and Late Bronze Ages (circa 2000-1200 BC). Syro-Canaanite remains preferable to the term 'Canaanite' as at Ugarit, located in modern-day northern Syria, Canaanites were regarded as foreigners and more suitable than the term 'Phoenician', for although this culture derived from the Canaanites, it evolved its own material culture, which differed from its Bronze Age antecedents (Rainey 1963, 1996; Mazar 1990, pp. 355-57; Mazar 1992, pp. 296-97). On the borders of Canaan proper, see (Rainey 1996; Rainey and Notley 2006, pp. 34-36). 
It is all important, therefore, that an inquiry should be made into the reliability of these pictures, and it is as well to realize at the outset, to prevent disappointment, that modern standards of historical exactness will have to be imported by us into the study of these records. We shall not find them ready for us there ... Burbage, the inventor of the calculating machine, was once asked by a lady whether, if he put in the wrong figures, it would still come out right! Mathematics suggests that the value for knowledge of the above quotient would be relative to the accuracy or inaccuracy of the "facts", multiplied by n (the number of items used), but would demand that minus quantities (the silence and lacunae of the sources) should rank equally with plus quantities in the calculation. History is not in the least an exact science. The vaguest branches of knowledge have much wider room in them than arithmetic has. The ideal historian is he who to a base of great industry adds in perfect proportion the strong acid of purified scepticism and the rare precipitant of refined telepathy.

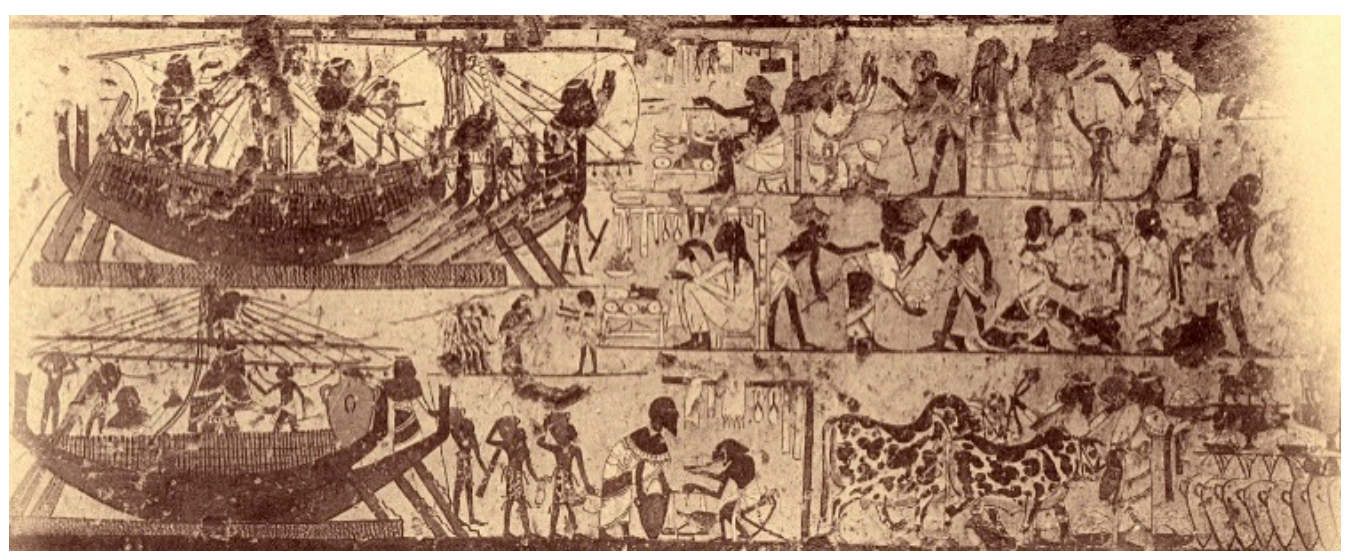

(a)

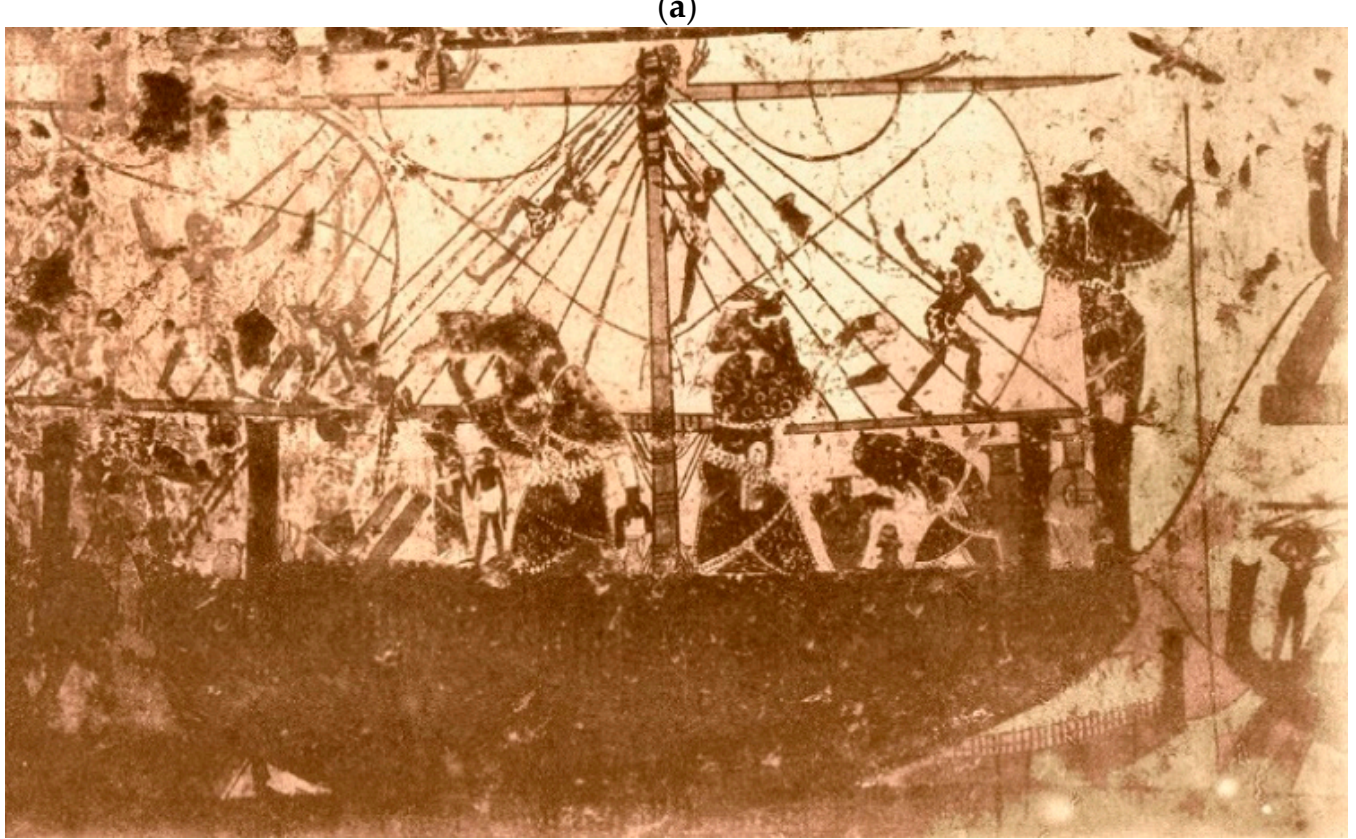

(b)

Figure 4. Early photos of the tableau of Syro-Canaanite ships in the tomb of Kenamun (TT. 162; Amenhotep III). This wall painting no longer exists. (a) Center and right side of the scene depicting ships docked at an Egyptian harbor and trading activities. Note particularly the scribe recording slaves(?) and the man above him with a staff whose head is hidden behind the bow of the ship. (b) Large ships on the left side of the scene. After (Daressy 1895, pl. XIV-XV). 


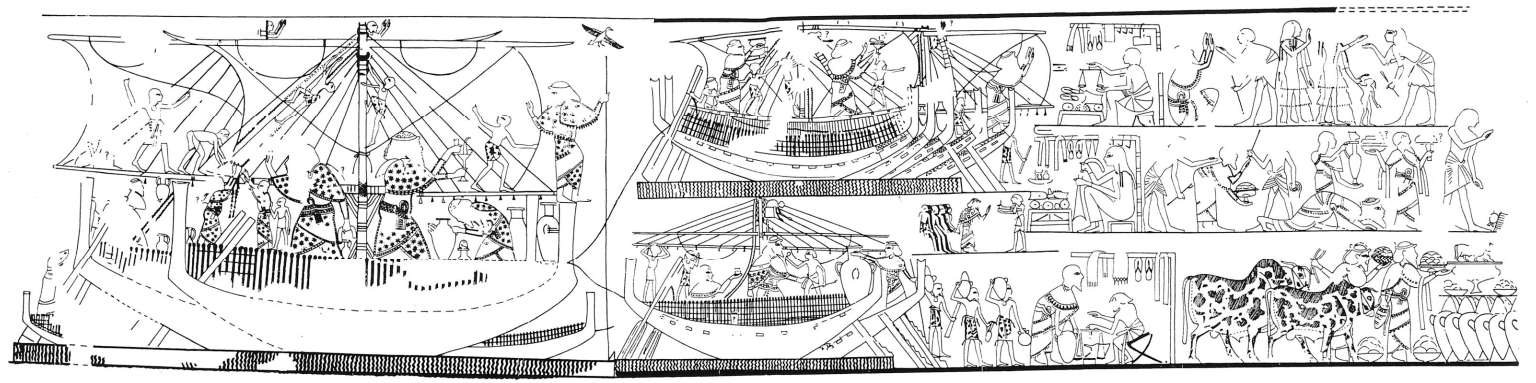

(a)

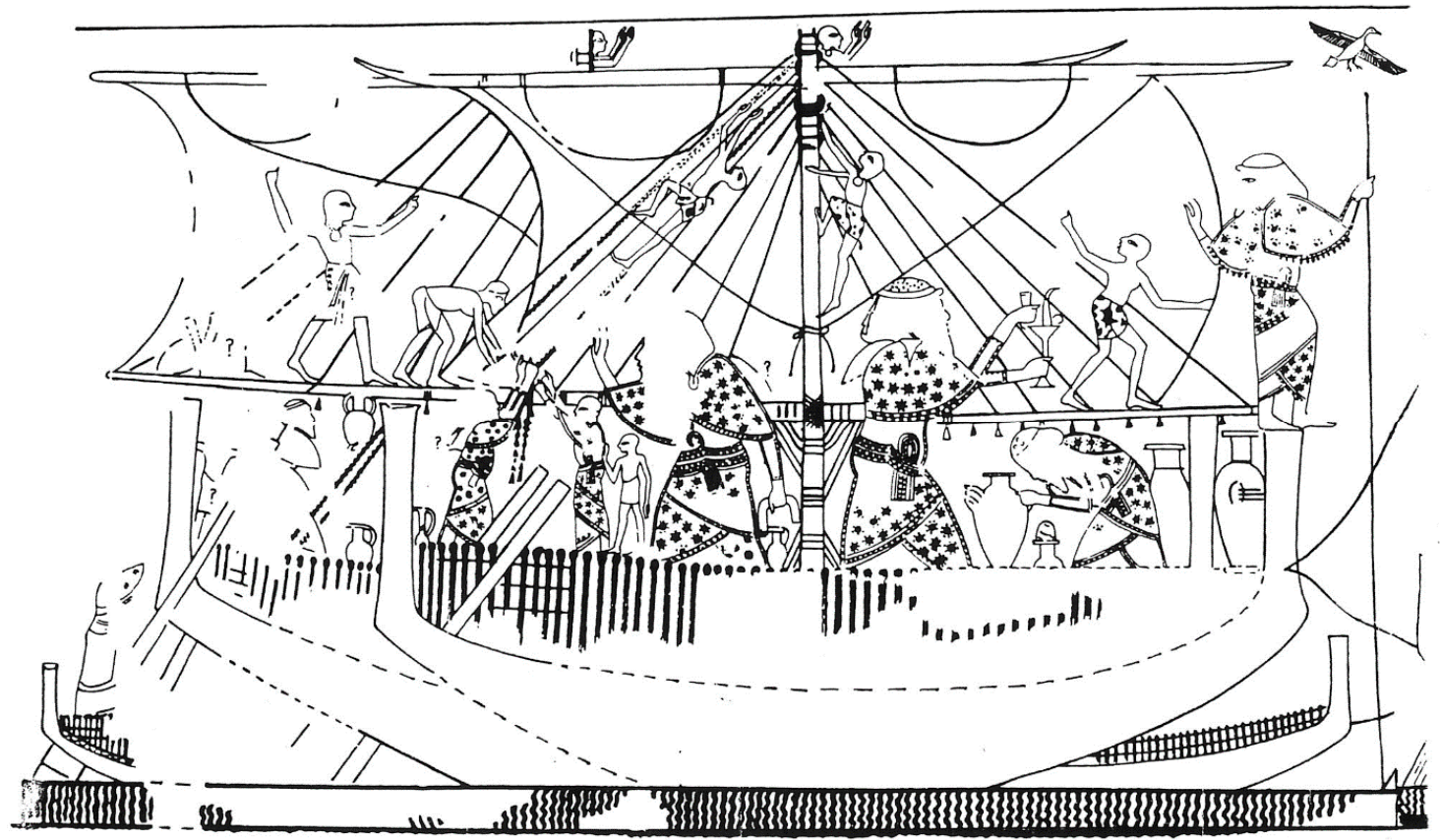

(b)

Figure 5. (a) Line drawing of Syro-Canaanite ships in the tomb of Kenamun (TT. 162; Amenhotep III).

(b) Detail. After (Davies and Faulkner 1947, figure VIII).

In a well-known series of works—La trahison des images, Les deux mystères, L'air et le chanson, etc.- the Belgian surrealist painter René Magritte portrayed a smoker's pipe with this comment below it: "Ceci n'est pas une pipe" (Figure 6) (Torczyner 1979, p. 71 figure 87; Hammacher 1985, pp. 25, 27-28 figures 33-34, 29-30; Sylvester 1992, pp. 168-70). Here, Magritte correctly addresses perhaps the single most important consideration in the study of ancient iconography in general, and specifically the iconography of ancient ships: a representation of a ship is not the ship itself. This might seem an obvious, as well as unnecessary, observation, but keeping it in mind serves well in trying to make sense of ancient ship iconography.

Whether two or three dimensional in nature, representations of ancient vessels are projections both reflected and refracted through their materials and the artistic styles—or, more often than not, the lack of any artistic style - of their creators. Such prosaic conditions as the space that is available to an artist when creating a two-dimensional representation of a ship, the material selected for the production of a ship model or the model's purpose can introduce drastic deviations from the prototype vessel. Details that caught the eye of the artists and what they chose to emphasize in their depictions all play roles in the shaping of an ancient ship image. We must inquire into the source of the artist/artisan's actual knowledge of the ship that is portrayed. 


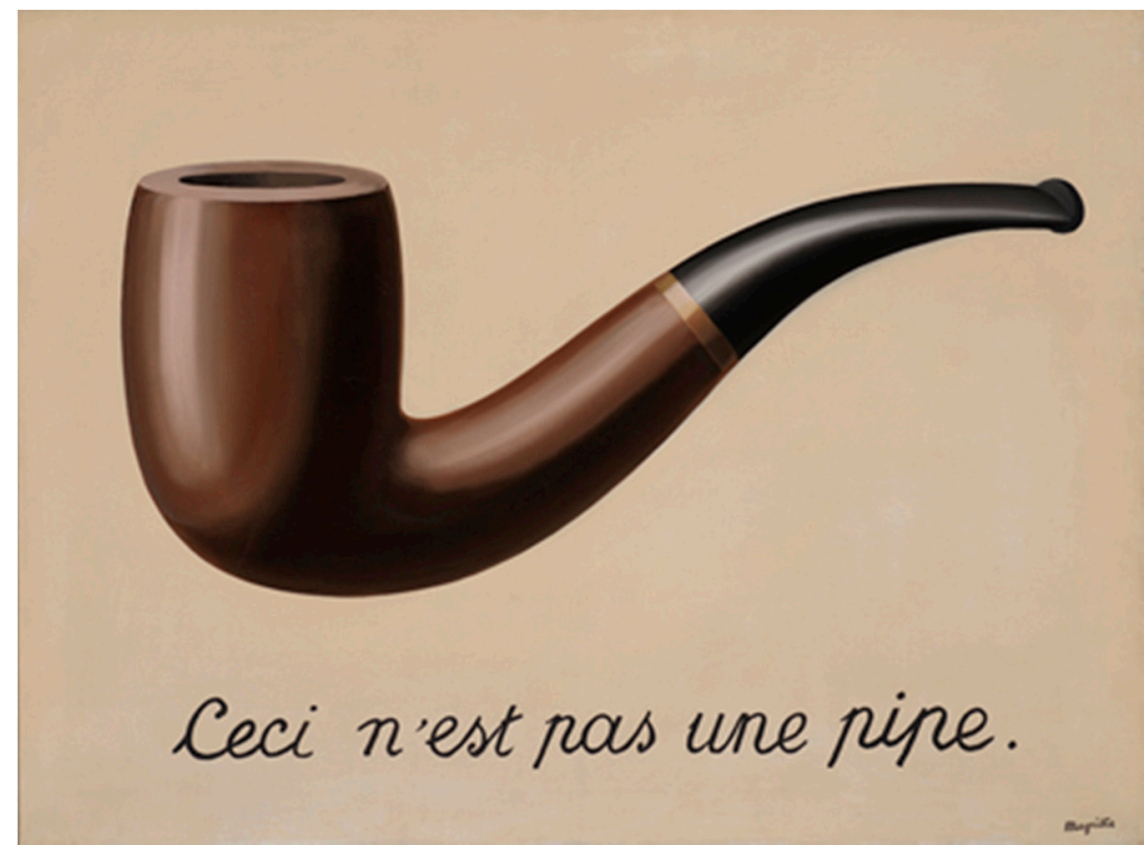

Figure 6. Magritte's warning. "Ceci n'est pas une pipe". La trahison des images. (C) 2019 C. Herscovici/Artists Rights Society [ARS], New York).

Harry Tzalas (1990) supplies an excellent introduction into some of the complex decisions that might cause the representation of a ship to diverge from the reality of the prototype vessel. He describes a fresco in the Church of the Holy Cross in Pedoula, in the Nicosia region of Cyprus that has a commissioned representation of the Kyrenia II, a sailing replica of the eponymous shipwreck of a late fourth-century BC merchantman that sank off the northern coast of Cyprus (Steffy 1994, pp. 42-59) (Figure 7). This figure is particularly informative, because, as Tzalas notes, we know all details of the Kyrenia II, as did Alkis Kepolas, the iconographer who painted the fresco. An avid photographer, Kepolas documented the modern ship during its construction in harbor, so he was well familiar with his subject when he painted it. Thus, this image supplies us with a remarkable opportunity to study the changes in the representation of a prototype ship about which we know all of the details.

We might expect that this competent artist would accurately depict the ship in the fresco, but such is not the case. Tzalas notes that the depiction contains numerous deviations from the original and divides these into three groups: (A) errors resulting from a lack of understanding of the vessel (11 items), (B) intentional changes required to permit the ship to appear in a Byzantine-style fresco (five items), and finally (C) changes both in addition and omission essential for a 'pagan' ship to appear in a Christian church (seven items).

In the first category, unintentional errors, Tzalas includes changes in representing the positioning of the topping lifts, the yard represented as a single timber when, in fact, it was of tripartite construction and had a distinct downward curve at the extremities, incorrect proportions between the hull, the mast, and the yard, the quarter rudder faces in the wrong direction and shows no attachment to the hull, no blocks appear in the image, nor is the wale depicted, and so on.

In Tzalas' second group, which consists of intentional errors resulting from a need to have the image conform to Byzantine fresco techniques, he includes details of the sail, which lacks its seams and appears to hang like drapery, many rigging details that have gone missing, only four strakes appearing above the assigned water line, and so forth.

In his third classification, those changes that result from the need for the image to comport to ecclesiastic representational art, Tzalas includes the appearance of the Holy Virgin in the center of the 
sail, a cross topping the mast, the side screen carries the acronym "IC XC" (Iisous Christos), and the lack of the replica's apotropaic, but pagan, opthalmoi (eyes), among others. ${ }^{4}$

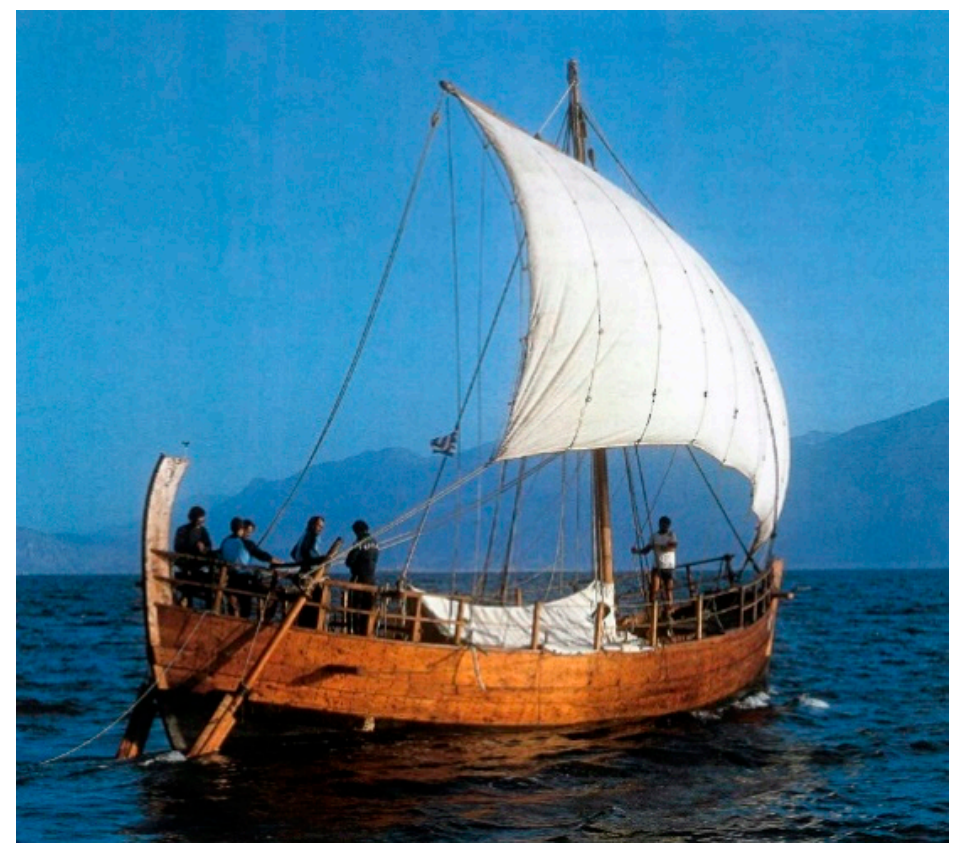

(a)

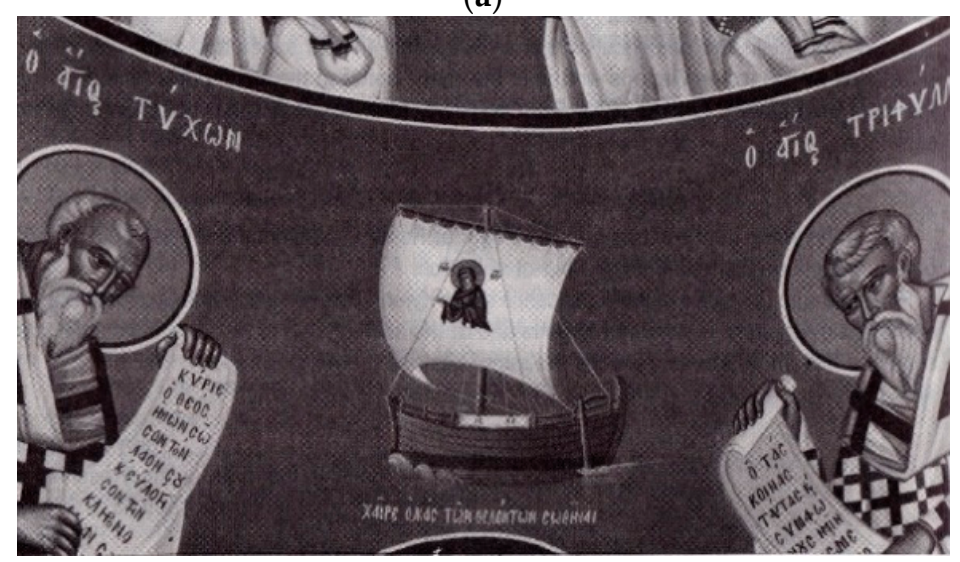

(b)

Figure 7. (a) The Kyrenia II with her brailed sail set. This vessel is a modern reconstruction of the Kyrenia ship, which sank off the north coast of Cyprus at the end of the fourth century BC. (b) The Kyrenia II represented in a fresco, in the church dedicated to Panaghia tou Pedoula, the Virgin of Pedoula, Cyprus. Courtesy of Harry Tzalas, President, The Hellenic Institute for the Preservation of Nautical Tradition. (b) from (Tzalas 1990, p. 326 figure 1).

In total, Tzalas lists a stunning 23 considerations for changes made to this single representation that cause it to differ from the prototype, even though the artist had complete knowledge of the original. In addition to these types of errors, the observer must keep in mind the consideration that the visual evidence itself might vary widely, from reliefs made based on first-person observation to images pecked on a rock with a handy stone by a bored shepherd based on stories heard.

4 On ships' eyes (Gk. opthalmoi; Lat. oculi), see (Hornell 1938a, 1970, pp. 285-89; Casson 1995, pp. 64, 212 no. 49, figures 119, 65-68, 72, 81, 91, 107, 115, 119-122, 125-126, 145, 191-192; Nowak 1999, 2001, 2006, and there additional references). 
With all of these bewildering possibilities for original error, as well as many others that can lead any modern researcher to inaccurate interpretations, what is the correct approach for the study of ancient ship iconography that will lead to conclusions that approach past realities?

Consider the parable of the Indian blind men, each of whom, when instructed to identify the essence of an elephant by touching only one part of it—trunk, ear, body, leg, or tail—came away with 'logical' conclusions that an elephant most closely resembled, respectively, a snake, parchment, a wall, a tree, or a rope (Goldstein 2010, p. 492).

This parable contains an essential lesson: like the blind men, we who study the past can touch it but we cannot see it. Viewing the past through any single lens results in a myopic, and, thus, an inferior, result. The task before us requires a truly holistic approach. We must meticulously scrutinize every available source of information relevant to the task. Metaphorically speaking, the goal must be 'to touch as many parts of the elephant as possible'.

For the study of ancient ships, in addition to iconography, three other possible primary sources of evidence must be considered critically whenever available and relevant:

Textual evidence-Any pertinent contemporaneous written information must be evaluated to determine whether it can contribute to a better understanding of the image under study. Texts may deal with ships, their construction, their nationalities, their destinations, as well as a myriad of other considerations as, for example, a change in terminology that may supply an explanation for the odd manner in which artists depicted Noah's Ark in Late Antiquity. ${ }^{5}$

Archaeological evidence-The actual remains of vessels and their equipment are, of course, of intrinsic relevance. Ships, subject to the comments above regarding preservation, remain the main source for our understanding of hull construction techniques and the shapes of vessels along with myriad other details. Shipwrecks still can surprise regarding aspects of the upper structures of ancient hulls. Note, for example, the discovery of fragments of a wickerwork fencing on the Uluburun shipwreck, which supplies an important archaeological confirmation to the fencing that is depicted on representations of Syro-Canaanite ships as they appear in the tombs of Kenamun and Nebamun (TT 17; Amenhotep II) New Kingdom nobles at Thebes (compare Figure 8 to Figures 4, 5 and 9) (Pulak 1992, p. 11 figure 12; Pulak 1995, p. 54 Abb. 25; Pulak 2008, pp. 302, 303 figure 99; Wachsmann 1998, pp. 44-45, 51, 56, 217). ${ }^{6}$

Ethnographical evidence-At times the manner in which ancient cultures perceived their world seems to be inexplicable to modern observers. Comparisons to ethnographical parallels from the present, or the recent past, aid in penetrating the conceptual world of bygone times. Studying the construction, manners of propulsion, and use of traditional ships of the present and recent past, can provide valuable clues to research enigmas. Utilizing ethnographic materials from disparate cultures across the globe and over vast expanses of time does not argue for any direct cultural connection: rather, it addresses the consideration that the human psyche, given similar problems and available materials, will tend towards analogous solutions and expressions (see, for example, Hornell 1938a, 1938b, 1943; Wachsmann 1980, pp. 292, 293 figure 7, 294 figure 8, 295; Wachsmann 1998, pp. 71, 73 figure 5.6, 74 figure 5.7, 75, 77 figure

5 See below, Section 11. To Be or not to Be.

6 On the ship of Nebamun, see (Wachsmann 1998, pp. 45-47, and there additional bibliography). Samuel Mark (2017) identifies the Nebamun ship as Egyptian rather than Syro-Canaanite, but this vessel remains irrevocably coupled to the scene in the register above it showing Nebamun, a physician, administering to a Syro-Canaanite personage, presumably the ship's owner (Figure 9a). This connection is so obvious that even Torgny Säve-Söderbergh (1946, p. 56), perhaps the most forceful advocate for the preeminence of Egyptian shipping, concedes the vessel's Syro-Canaanite identity. As J.J. Shirley (2007, p. 384) notes in her restudy of Nebamun's tomb "... the idea that the Syrian's presence would have no bearing on the remainder of the scene contradicts ancient Egyptian artistic principles generally and the conventions of tomb depictions in particular ... . Indeed, I am unaware of any New Kingdom tomb where a scene that is clearly the main component of a wall's decoration would have elements completely unrelated to each other." 
5.14, 78 figure 5.15, 79 figure 5.17-18, 80 figure 5.19-21, 81 figure 5.22, 185 figure 8.44, 190, 193 figure 8.60, 194 figure 8.63, 195, 196 figure 8.65, 197 figure 8.66-67; Wachsmann 2002a; 2002b).

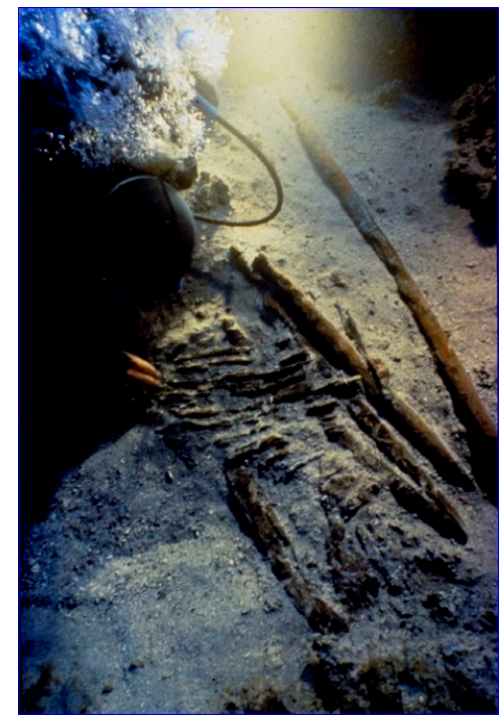

Figure 8. Weather fencing on the Uluburun shipwreck. Photo: D. Frey. Courtesy Institute of Nautical Archaeology.

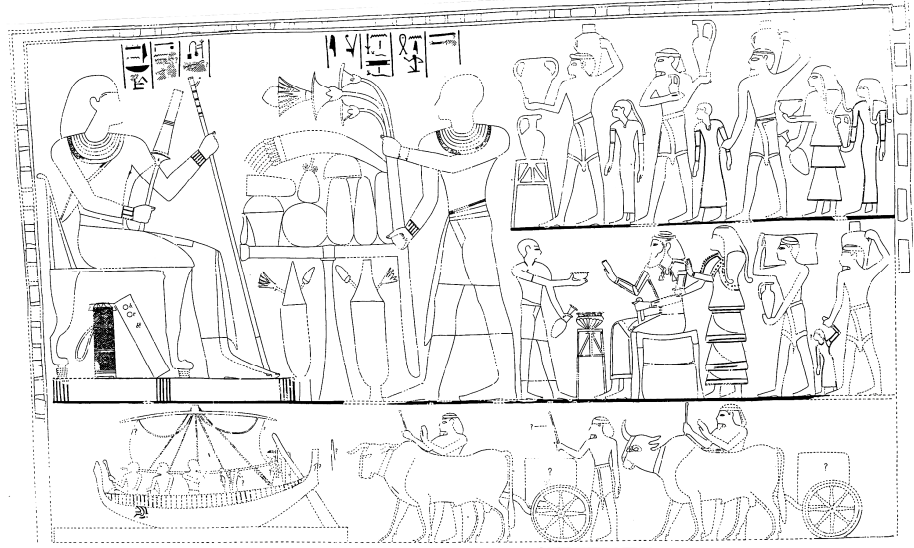

(a)

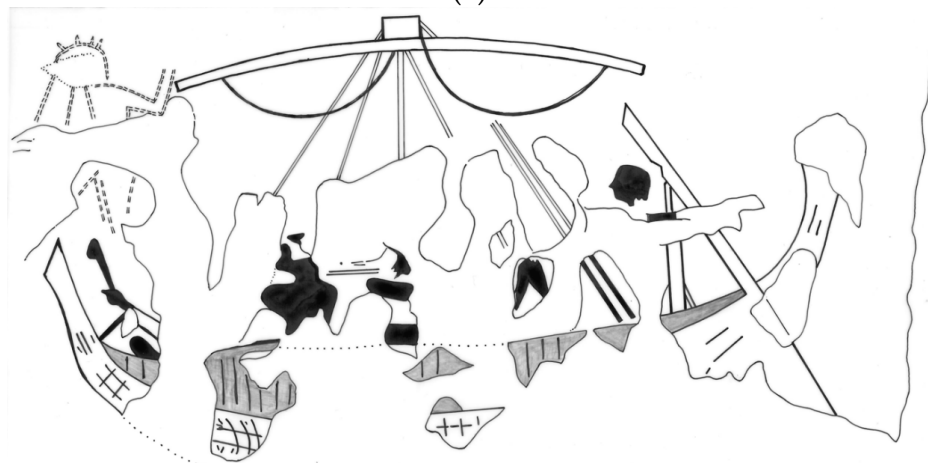

(b)

Figure 9. Scene from the tomb of Nebamun (TT. 17; Amenhotep II). (a) In the right center register Nebamun administers to a Syro-Canaanite personage, presumably the merchant owner or captain of the foreign ship that appears at the left of the lowest register; and, (b) Detail of the ship. (a) after (Säve-Söderbergh 1957, pl. 23); (b) after (Müller 1904, Taf. 3). 
The following pages contain concerns and approaches for the study of ancient ship depictions, based on over four decades of studying these fascinating ancient treasures. To be clear, these comments only represent a few of the necessary considerations when trying to understand the nautical iconographic information left to us by the ancients. A complete checklist is beyond the scope of this paper.

One writes about what one knows: below, I mainly use my own research as illustrations, including, in some cases, my own errors, as cautionary tales. My interest in ancient ship iconography has focused primarily, although not exclusively, on vessels and seafaring of the Bronze and Iron Ages in the eastern Mediterranean. The following examples primarily spring from those epochs and that region. I particularly focus on a type of galley, or oared ship, with an open rower's gallery that appears at the end of the Late Bronze Age in use by the Mycenaean Greeks and later by the Sea Peoples, as this particular corpus of ship images elucidates a number of pertinent issues. The concepts discussed here, however, should be applicable to ship imagery farther afield in time and space.

\section{Shaving with Occam's Razor}

The first step in any study must be meticulous documentation of all types of possible evidence relevant to the ship representations under consideration. ${ }^{7}$

Be aware of the crucial role of seemingly invisible personal biases, as demonstrated by Amos Tversky and Daniel Kahneman in their Nobel-Award winning research (Tversky and Kahneman 1974; Kahneman 2011). Limit the effects of personal biases of which you may not be cognizant: do no harm. To try to contain my own biases, I endeavor to 'shave' my research approaches and conclusions with Occam's Razor, defined by Webster's Dictionary as, "a scientific and philosophical rule ... that the simplest of competing theories be preferred to the more complex or that explanations of unknown phenomena be sought first in terms of known quantities (Miriam Webster s.v. Occam's Razor. n.d)".

In other words, keep it simple. ${ }^{8}$ In fact, Occam's Razor serves as the single most effective guardrail against gaping chasms of bias, which one unfortunately all too frequently finds in the literature. Simply put, the more complicated the interpretation, the farther it is likely to stray from past realities and to enter the realms of modern scholarly conceits. To be clear, applying Occam's Razor does not ensure that one will reach a correct interpretation of the past: it will ensure, however, that one will reach the least incorrect one by precluding the introduction of conclusions based on personal biases.

Assume nothing. I am not referring here to a hypothesis, which indicates a formulated thought process. The hypothesis may prove right or wrong, but the process itself is driven by intent and by curiosity. As opposed to this, assumptions derive directly from bias.

A cautionary tale. The Gurob ship-cart model is the most detailed known representation of the type of galleys used by the Mycenaeans and adopted by the Sea Peoples in the waning years of the Late Bronze Age and the Early Iron Age (Figure 10) (Wachsmann 2013). The archaeological record currently lacks any examples of this ship type. Expressed colloquially, if Helen of Troy's face indeed launched a thousand ships, then at present the Gurob model is the closest that we can approach this ship type.

During the first several years of my research, I blithely assumed that the four wheels that were found with the Gurob model indicated that it had served as a simple child's toy (Wachsmann 2013, pp. 20, 21 figure 1.21, 22 figure 1.22). Eventually I had the good fortune to read an article by the Egyptologist George Legrain (1917) that dealt with the support base, termed by him a "pavois", which was used by the ancient Egyptians for transporting and storing cultic ships or ship-shaped palanquins. The loose pieces

$7 \quad$ For a good example of an exquisitely bad example in collecting evidence, see my own experience with the Gurob ship-cart model (Wachsmann 2013, pp. xvii-xviii).

8 In his review of my book on the Gurob ship-cart model (2013) Christoph Bachhuber (2013, p. 29) disparages my "repeated invocation of 'Occam's Razor'", which in his opinion "may work for aspects of ancient ship design" but "does not work for issues related to ethnicity and identity". In my view, Bachhuber here does not give sufficient consideration to bias, which is certainly not limited to issues of hull construction. 
that were found with the model included a small decorated wooden rectangle that clearly represents a pavois, meant to be pegged into a hole amidships on the bottom of the Gurob model (Wachsmann 2013, p. 20 figure 1.20). This led me to the dual realization that the model, far from being a toy, represented a cultic ship model, and, furthermore, it evinced a snapshot of syncretism: a European cult, represented by a model of a distinctly Aegean ship type, in an early phase of absorption into Egyptian cult indicated by the introduction of the pavois. As late as it came in my research, this understanding introduced an additional, and for me unexpected, dimension of cultural and cultic interconnectivity, changing the direction of my study of the model (Wachsmann 2013, pp. 85-162, 202-3).

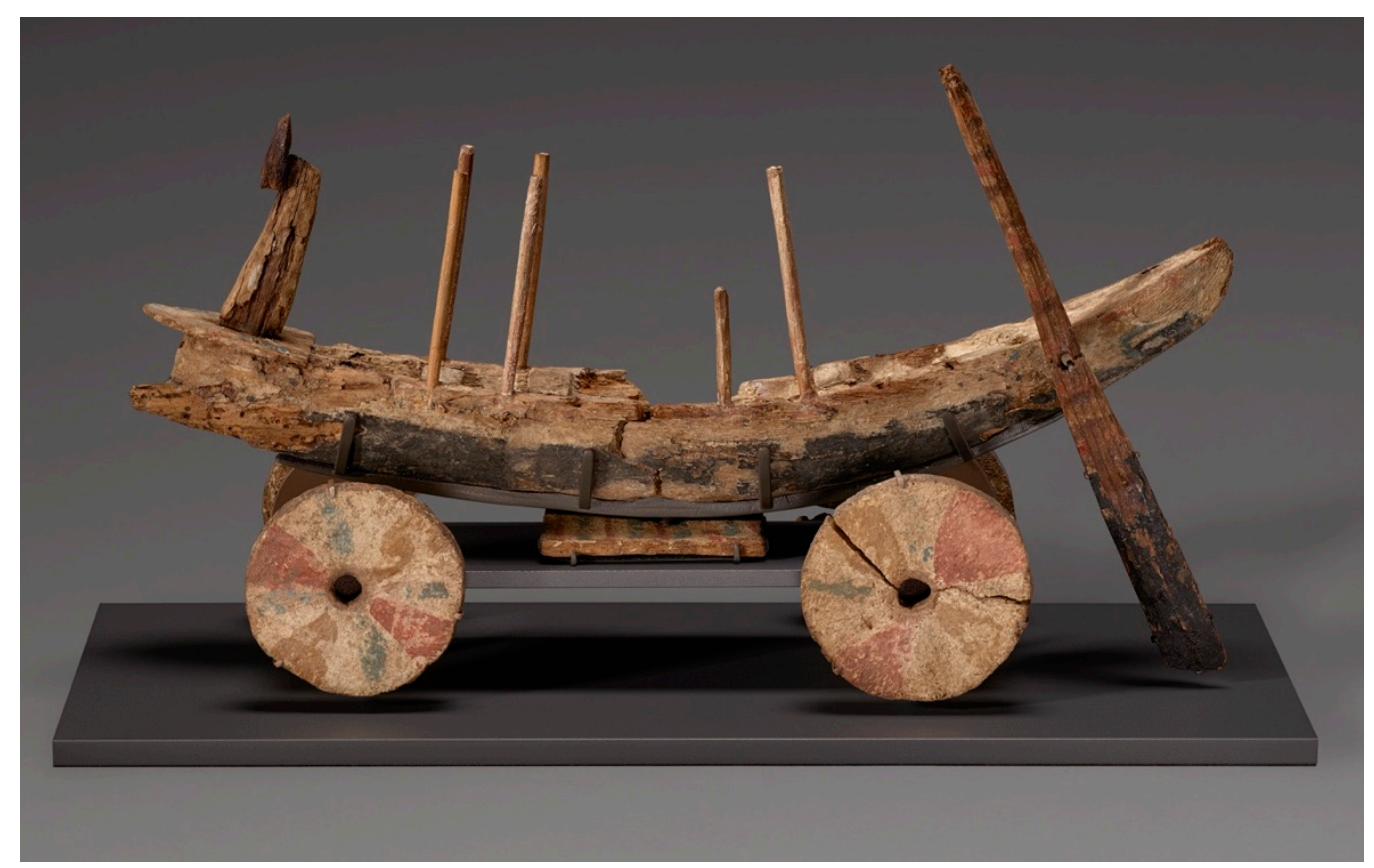

Figure 10. The Gurob ship-cart model. Date: 13th-12th centuries BC. Note the pavois beneath the hull. Courtesy of the Petrie Museum of Egyptian Archaeology, University College, London.

I still shudder to think about how mediocre my research on the Gurob model could have turned out had I missed Legrain's publication, simply because I had assumed (bias) that the accompanying wheels identified it as a toy.

Assume nothing.

\section{From Detail to Abstract}

When dealing with any corpus of ship representations, study them from the most detailed representation to the most abstract or poorly executed. A series of Minoan 'talismanic' seals demonstrate this concept (Figure 11) (Betts 1968, 1973; Onassoglou 1985, pls. 12-13; Basch 1987, pp. 94, 95 nos. A1-9, 96 nos. A10-18, 97 nos. A19-28, 98 nos. A29-35; Wachsmann 1998, pp. 94, figure 6.18, 99, 101; Wedde 2000, pp. 341-49, figures 921-53, 959-60, 962-63, 966-68, 971-73, 978-79, 981). The artisans who created these gems situated the salient cult items - the bird (swallow) decoration and the ship's cabin (Gk. ikria), located respectively at the bows and sterns of the prototype ships-together on a thumbnail-sized canvas by reducing the hulls' length. ${ }^{9}$ By placing the scenes in the order of their progressive abstraction, and then by comparing them to the most detailed representations of these vessels (the procession-scene ships from Thera, as discussed below), the enigmatic aspects of these seals 
become apparent. ${ }^{10}$ Trying to impart accuracy to the placement of these details misses the intention of the seals' creators and negates the value of their evidence. To paraphrase Magritte, these are not ships.
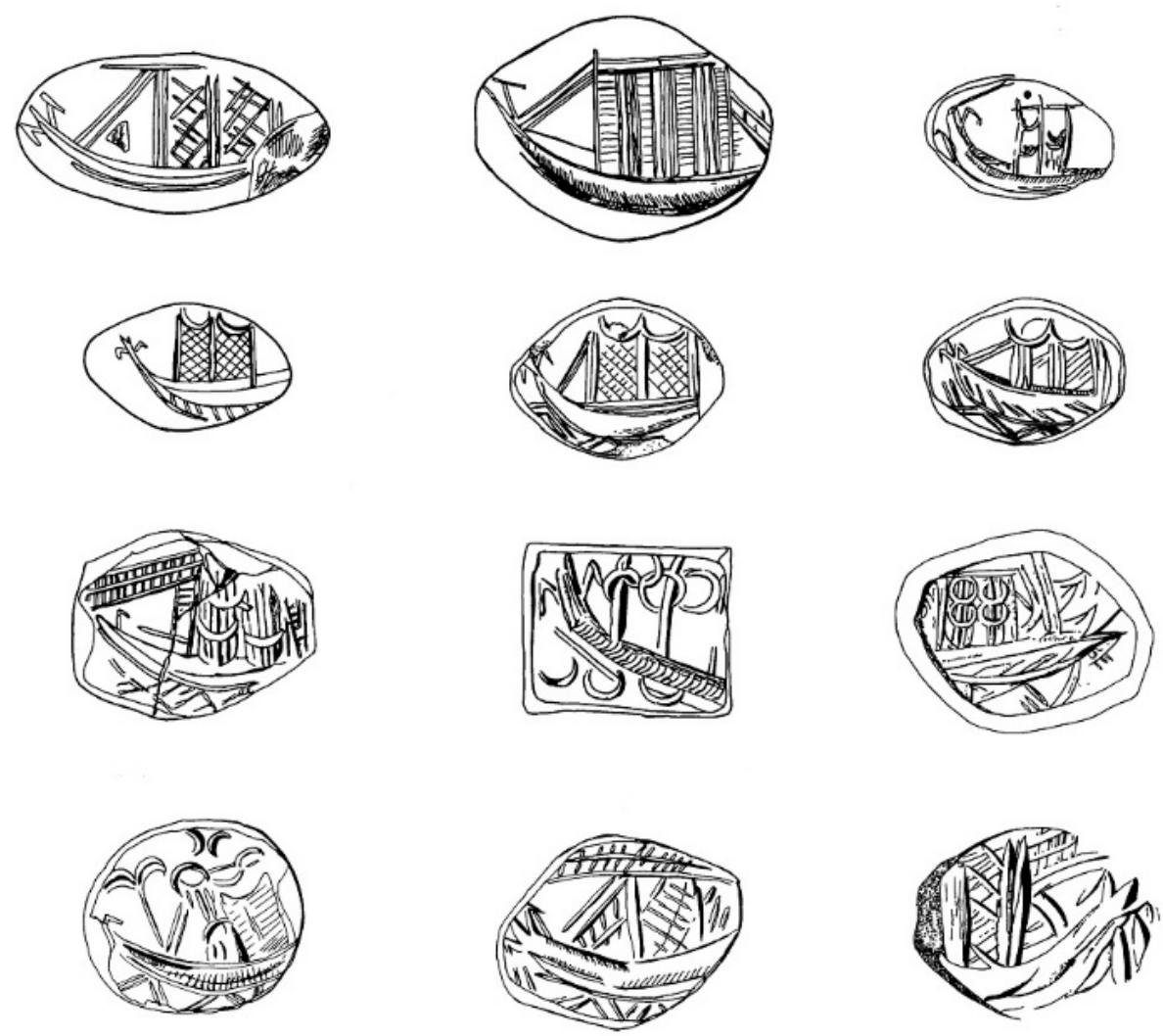

Figure 11. Late Minoan 'talismanic' seals depicting the progressive abstraction of the stern castle (ikria) and ships' bows. From (Wachsmann 1998, p. 98 figure 6.25) after (Marinatos 1933, pls. XV: 42, 43, XVI: 44-51; Casson 1995, figures 44-45).

\section{Question the Source}

Today, one can place an original image on a photocopier and copy it, and then make a copy of that, and so on. Each new image loses resolution. The same holds true for ancient ship depictions. What is the source of a ship's image? Does the representation derive from the artist's personal knowledge or is it based on a secondary or even a tertiary source? Did the artist ever actually see the prototype vessel?

The female pharaoh Hatshepsut sent a trading fleet to the land of Punt, located somewhere along the southern Red Sea coast (Kitchen 1971). Unlike other pharaohs who sent expeditions to Punt, but did not record them in imagery for posterity, she chose to depict this expedition on the walls of her mortuary temple at Deir el Bahri (Naville 1898, pls. 72-75; Säve-Söderbergh 1946, pp. 8-30; Casson 1995, pp. 21-22 figure 18; Wachsmann 1998, pp. 17-29). This tableau remains one of the best known of Egyptian nautical representations and also one of only a handful of ancient Egyptian representations of seagoing ships (Figure 12). The vessels impart a distinct impression of authenticity.

10 See below, Section 8. Cultural Continua, figure 29. On Minoan/Cycladic stern castles (ikria), see (Marinatos 1974, pp. 49, pls. 100, 108, 11s, color pls. 4, 9; Van Effenterre 1978; Shaw 1982; Doumas 1983, p. 32, color pl. XI; 1992, pp. 60-70 figures 35, 71-74 figure 36, 75-77 figure 37, 80 figure 39, 81 figure 40, 86 figures 49-50, 87 figure 51, 88 figure 52, 89 figures 53-54, 90 figure 55, 91 figure 56, 92 figure 57, 93 figure 58, 94 figures 59-60, 95 figures 61-62; Wachsmann 1998, pp. 93 figure 6.14-15, $94,99,111$ figure 6.48). 


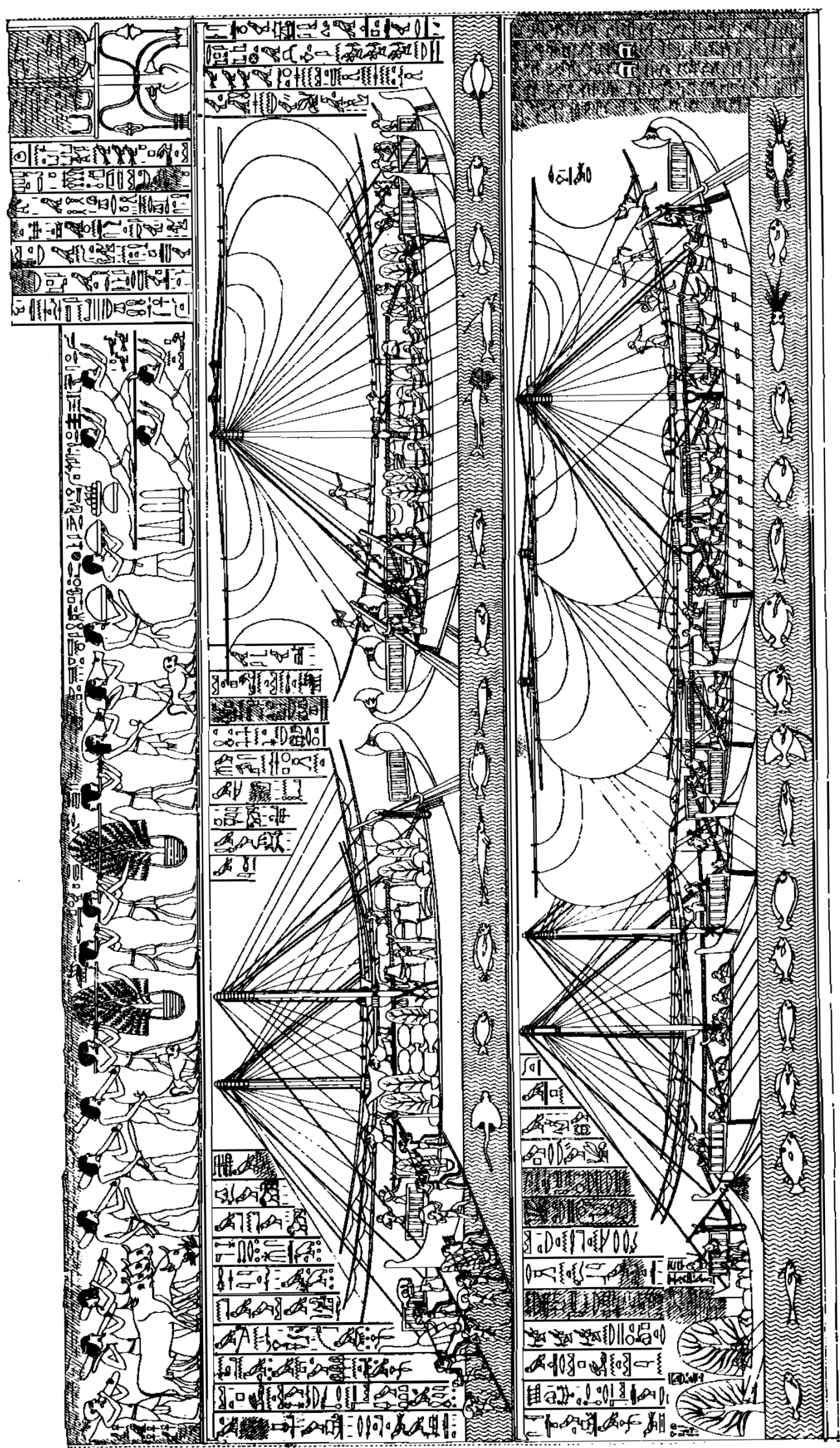

Figure 12. Hatsheput's seagoing Punt ships from her mortuary temple at Deir el Bahri. Note how the yard lifts on the ships with sail raised on the right of the tableau appear swept to the sides, when in reality they would have hung in pendant arcs. After (Säve-Söderbergh 1946, p. 14 figure 1). 
Indeed, the relatively accurate anatomical depictions of Red Sea fish and other sea creatures that appear in the strips of water beneath the ships indicate that the scenes, including the ships, are based on first-hand observation (Figure 13) (Danelius and Steinitz 1967; Wachsmann 1998, pp. 19, figure 2.14, 21 figures 2.15-16, 22 figures 2.17-18). Artist(s) that participated in the expedition presumably sketched these creatures after they had been caught, but before they ended up in the cooking pot. These details supply credence to the ship depictions, as well as to the remarkable adjacent portrayals of sub-Saharan Africa, the earliest of their kind (Naville 1898, pls. 69-72, 78).

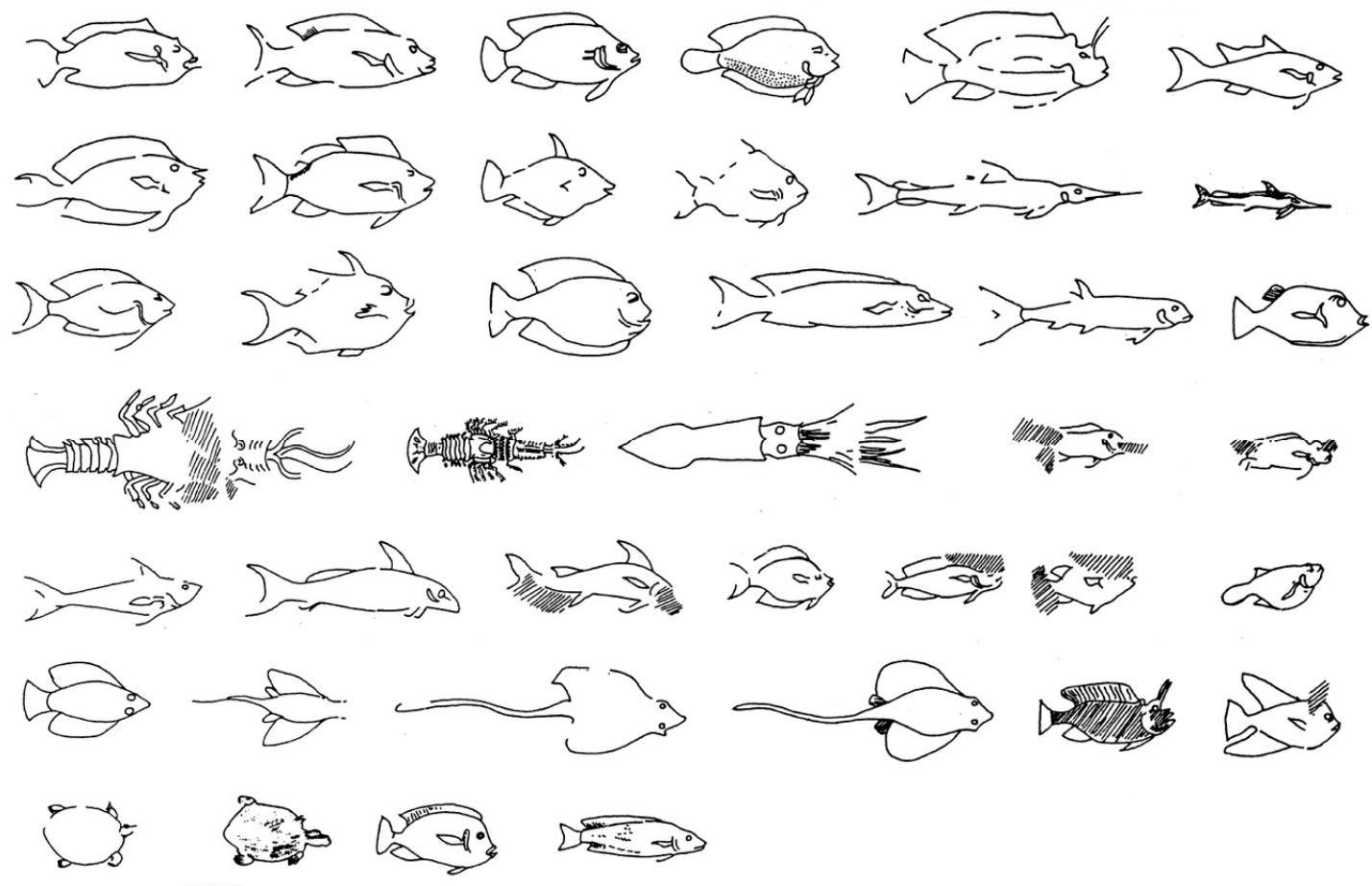

Figure 13. Fish and other marine fauna appearing in the strips of water beneath Hatshepsut's Punt ships at Deir el Bahri. From (Wachsmann 1998, p. 19 figure 2.14 [after Naville 1898, pls. 69-70, 72-75]).

Even so, intentional errors have been introduced into the scene. Some fresh-water Nile fish swim happily along together with the salt-water sea creatures. They have been moved from other aquatic scenes in what Heinrich Schäfer (1974, pp. 160-62) terms 'association of idea', and what I prefer to call 'transference' (Wachsmann 1987, pp. 11-12, 78-92). Note also that the lifts of the yards of the ships under sail are swept back in looping concentric arcs, in an impossible manner, rather than overlapping, as they would have done in reality. In making this change, the artists created a tidier, more elegant, and more symmetrical, but decidedly less accurate, depiction (Figure 12: ships at right).

A second celebrated Egyptian wall relief, on the northern exterior wall of Ramses III's mortuary temple at Medinet Habu, depicts a naval battle-the first ever recorded in art-in which Ramses defeated a coalition of Sea Peoples in his Year 8, circa 1176 BC (Figures 14-16) (Epigraphic Survey 1930, pls. 36-40; Nelson 1943; Wachsmann 1981; 1982; 1998, pp. 166-75; 2013, pp. 33-40). 


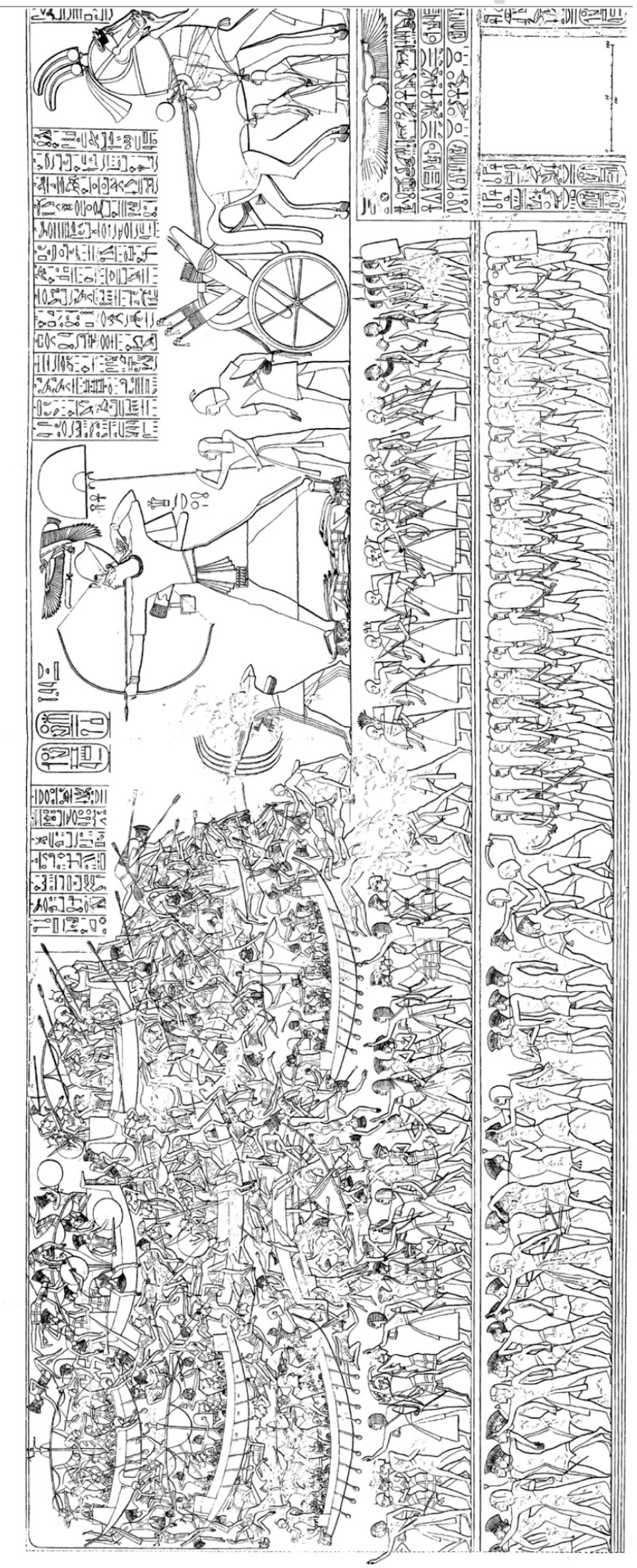

Figure 14. The complete scene of the naval battle against the Sea Peoples. Medinet Habu, Ramses III. From (Epigraphic Survey 1930, pl. 37). Courtesy of the Oriental Institute of the University of Chicago. 


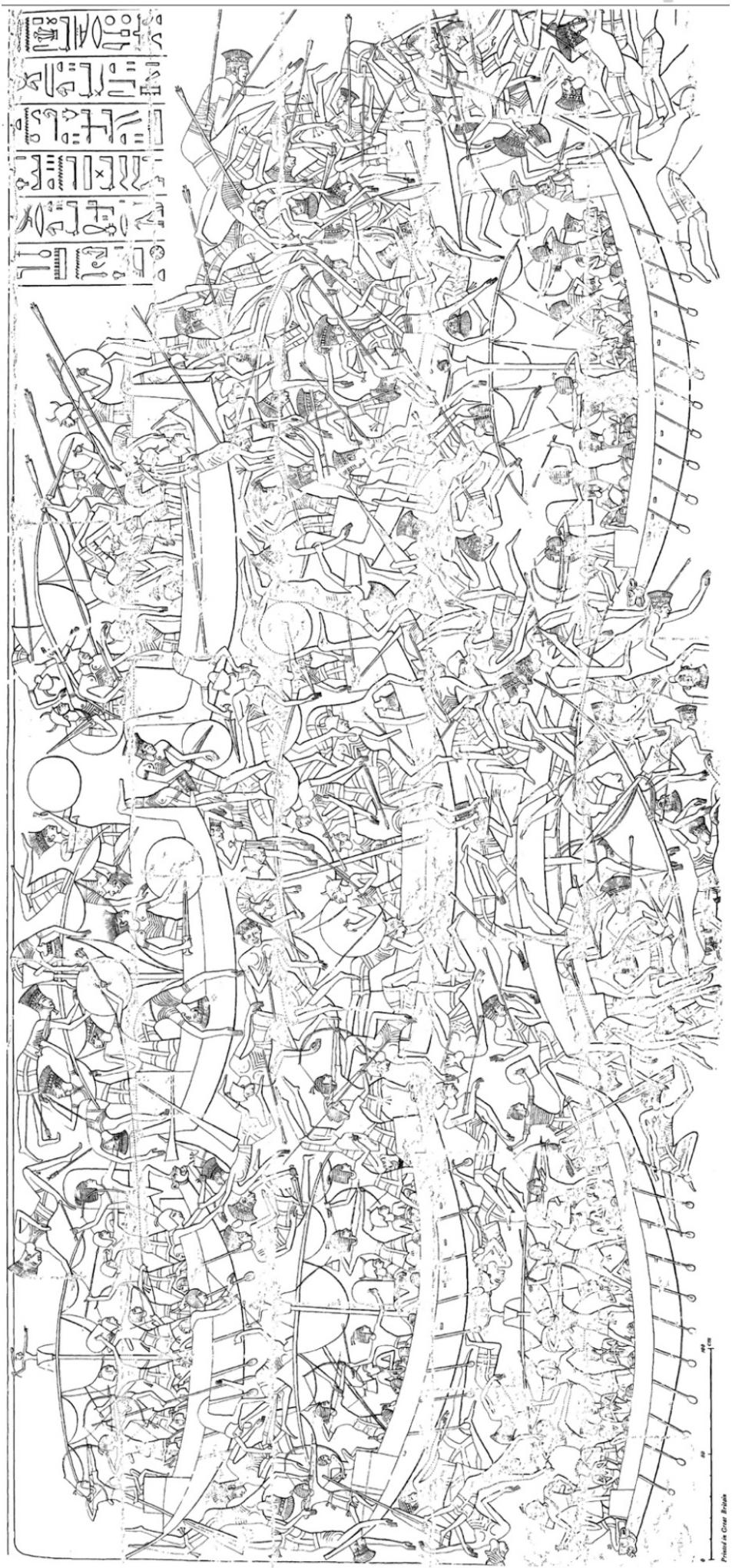

Figure 15. Detail of the naval battle. The detail supplied in these representations indicate that the Medinet Habu artists must have worked from records derived from person(s) who had actually seen and recorded at least one of the invaders' vessels. A drawing, or perhaps a detailed sketch, by an Egyptian military artist, made after the battle could reasonably have been the source for the multiple appearances of a single Sea Peoples' ship. Certainly, the graphic depiction of an enemy ship in the process of being capsized by means of a grapnel conveys a gripping element of reality derived from direct observation (Figures 16-18) (Wachsmann 1998, pp. 317, 318 figure 15.1-2, 319 15.3-4). From (Epigraphic Survey 1930, pl. 39). Courtesy of the Oriental Institute of the University of Chicago. 


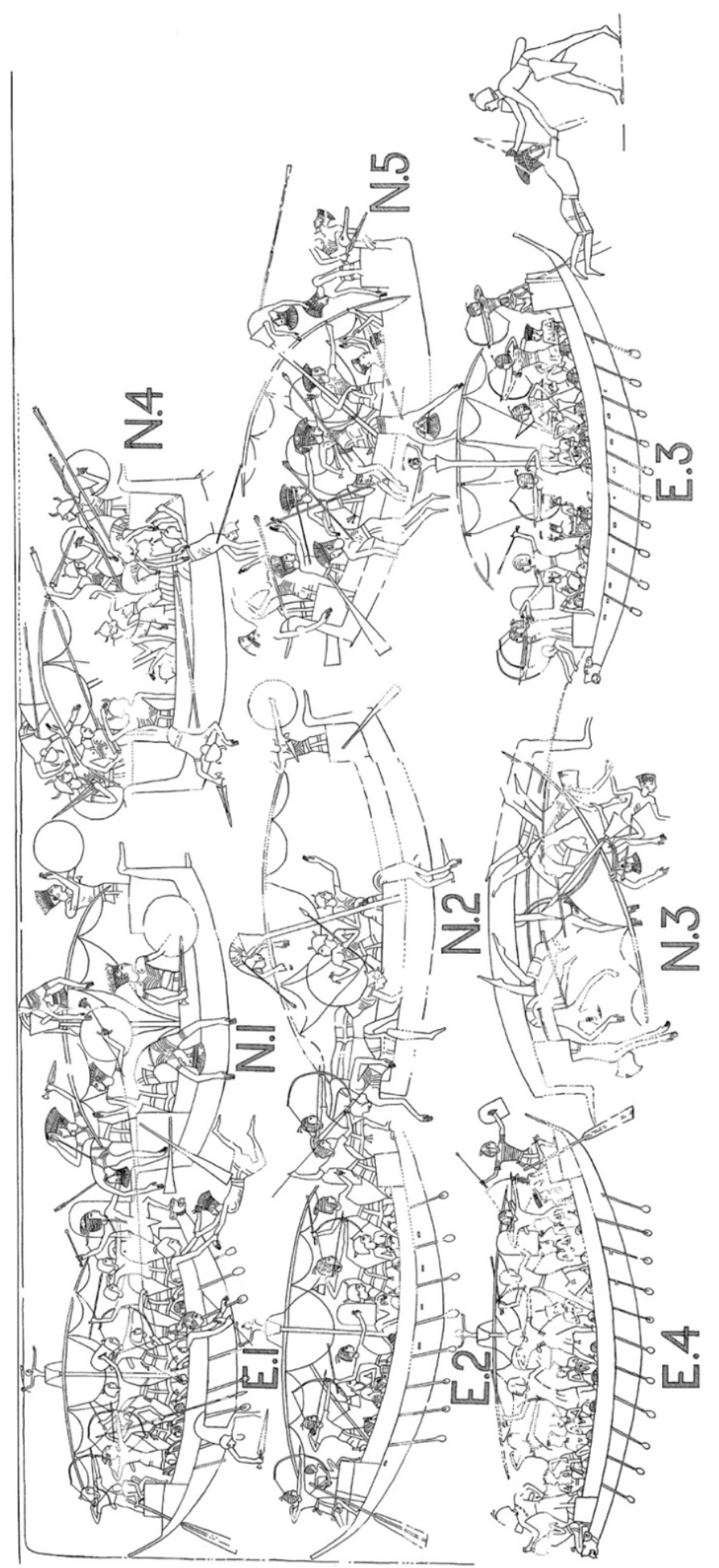

Figure 16. The naval battle scene with the floating bodies removed. From (Nelson 1943, figure 4). Courtesy of the Oriental Institute of the University of Chicago.

However, even at Deir el Bahri and Medinet Habu, the artists who recorded the Red Sea voyage and battle were unlikely to have been the same ones who carved and painted the scenes on the walls. In other words, the artists who imparted to us the voyage to Punt and the naval battle had probably never seen their prototypes. 


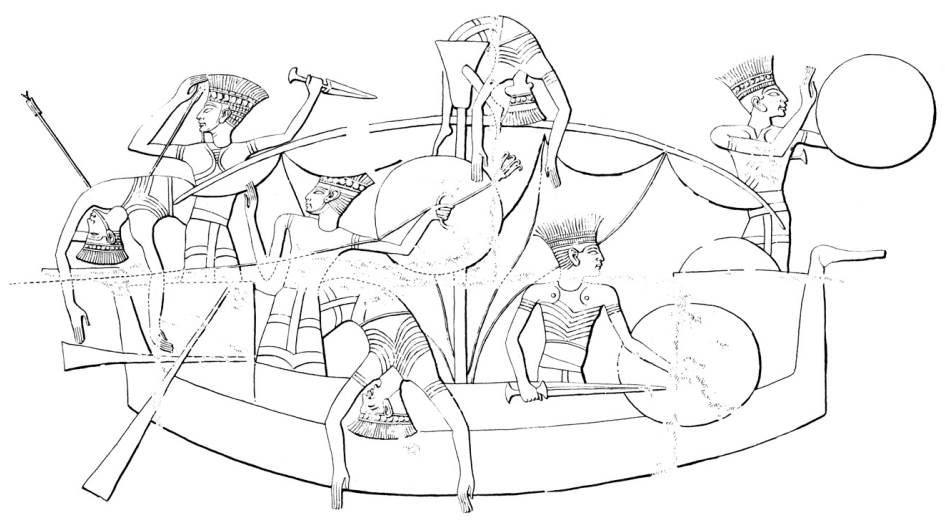

Figure 17. Sea Peoples' ship N.1, according to Nelson (1943) classification, with extraneous bodies removed. Note the Egyptian grapnel in the rigging and the manner in which the brailed sail, in its furled state, hangs in bunches beneath the yard. See also Figures 16 and 18. Medinet Habu, Ramses III. From (Wachsmann 2013, p. 38 figure 2.5) after the (Epigraphic Survey 1930, pl. 39). Courtesy of the Oriental Institute of the University of Chicago.

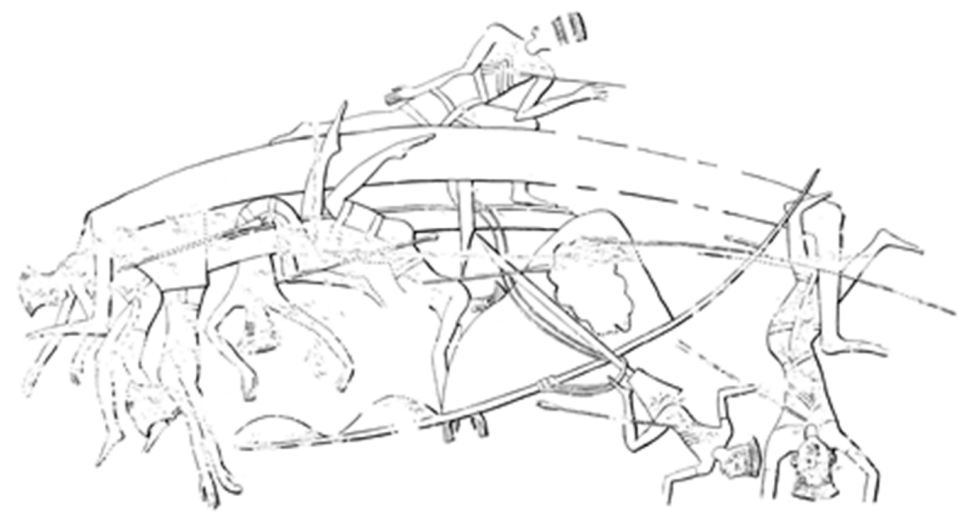

Figure 18. The Sea Peoples' capsized ship (Nelson's Ship N.3). Medinet Habu, Ramses III. From (Wachsmann 2013, p. 38 figure 2.6) after the (Epigraphic Survey 1930, pl. 39). Courtesy of the Oriental Institute of the University of Chicago.

In another instance, a terracotta ship model found at Byblos, on the Lebanese coast depicts a type of new Kingdom Egyptian Nilotic vessel (Figure 19a) (Dunand 1937, pl. CXL: no. 3306; Dunand 1939, pp. 223-25 no. 3306; Février 1949-1950, pp. 135 figures 2-3, 136-139; Landström 1970, pp. 106 figure 327-330, 107 figures 331-334, 108-109 figures 335-339, 110 figure 340; Jones 1990, pp. 28-37, pls. XVI-XXII, nos. 273, 284, 287, 306, 309-310, 314, 597 [Type B]; Wachsmann 1998, pp. 22 figure 2.20, 23 figures 2.21-22, 24 figure 2.23). Nile boats, as we understand them, would not have been able to make the journey from Egypt to Byblos across the Mediterranean Sea, and internal details regarding the Byblian model—a proto-keel seen projecting inside the hull—indicate that it could not have been based on a drawing. What source then did the model-maker draw on to create the Byblian model? One possibility is that the artisan replicated in clay an Egyptian wooden ship model, like those from the tomb of Tutankhamun, which had reached Byblos (Figure 19b) (Wachsmann 1998, pp. 52-54). This solution is problematic, however, as all of the known New Kingdom Egyptian wooden models of this ship type are constructed from solid blocks of wood (Figure 19b) (Jones 1990; Wachsmann 2013, p. 10 no. 19). However, what seems clear is that the creator of the Byblian model either saw a model with some internal structure depicted in it, or observed and copied an actual ship of this type (Wachsmann 1998, pp. 241-42). As the roughly contemporaneous Gurob ship-cart model—representing a foreign ship type but found in Egypt and probably created by an Egyptian artisan-does display some internal 
structure, the former possibility seems preferable, although I am not entirely satisfied with this solution (Wachsmann 2013, pp. 13 figure 1.13, 14 figure 1.14).

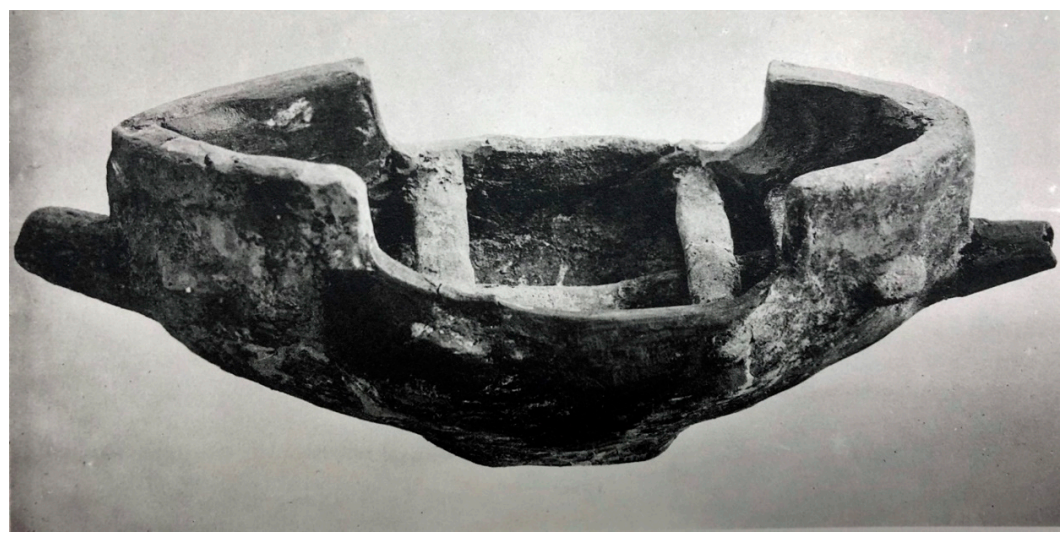

(a)
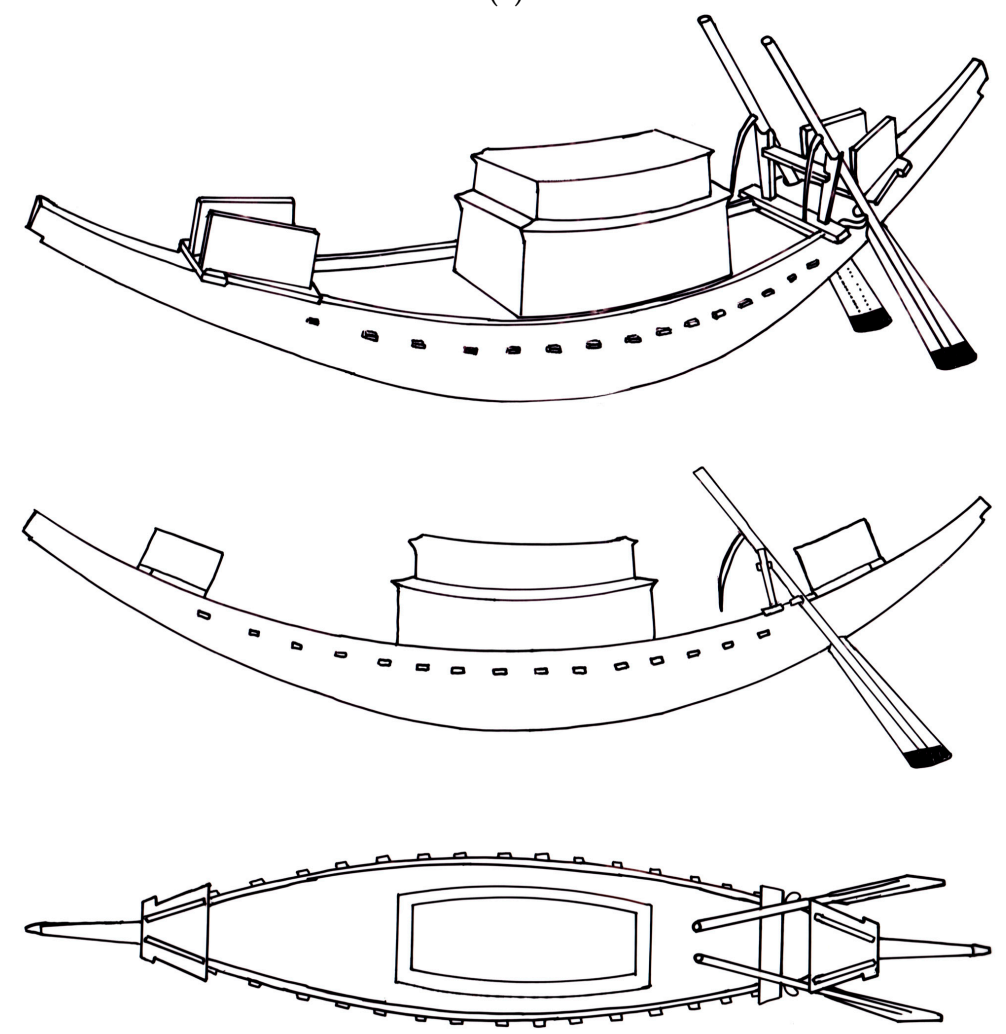

(b)

Figure 19. A terracotta ship model from Byblos (a) that appears to copy a type of Egyptian travelling ship exemplified by a wooden model from the tomb of Tutankhamun (b). NTS. (a) from Wachsmann 1998, p. 52. figure 3.16; (b) after (Jones 1990, pl. XXXII [Model Boat Obj. no. 284]). Drawings: (b): Megan Hagseth.

Other possible explanations exist. The creator of the Byblos model could have been either a local who had spent time in Egypt or an Egyptian expatriate living in Byblos or its environs. Both scenarios are possible. Visitations of Egyptian ships, not to mention Egyptians, along the eastern Mediterranean coast are witnessed in both textual and archaeological evidence. Specifically regarding ships, an inscribed axehead, belonging to an Egyptian royal ship of Cheops or Sahure, was found in the Adonis River (Nahr Ibrahim), just south of Byblos (Rowe 1936; Wachsmann 1998, pp. 11, 12 figure 2.1). Egyptian-style stone anchors with apical rope grooves and subsidiary L-shaped basal holes come from both Byblos and Ugarit (Frost 1969a, p. 443 Anchor 21, pl. V; Frost 1969b, pp. 238, 241, 244 
Table I: 11, 245 figure 11; Frost 1991, pp. 360-63, 371, 378 no. 9, 379, pls. IV-V; Wachsmann 1998, pp. 259 figure 12.7, 271 figure 12.28: 21, 274, figure 12.33: 11). Beginning in his Sixth Campaign (Year 30, circa 1449 BC), Thutmose III appears to have established a network of harbors along the Syro-Canaanite coast to support and supply ships transporting his army to and from Egypt, saving them the exhausting trek across the Sinai and the Levantine coast (Säve-Söderbergh 1946, pp. 33-36; Wachsmann 1998, p. 10). Egyptian officials and merchants appear in texts from several Syro-Canaanite cities (Rainey and Schniedewind 2015, Byblos: EA 105: 33-34, 114: 51-53; Sumur: EA 67: 6-16; Ugarit: Rainey 1967, pp. 88-89; Wachsmann 1986). When Wenamun shipwrecks on Alashia (Cyprus) he finds someone living there who speaks Egyptian who then serves as a translator between Wenamun and Heteb, the "princess" of Alashia (Wente 2003, p. 123).

If the evidence from Deir el Bahri and Medinet Habu, and, to a lesser degree, the Byblos model, give us a relative level of confidence of first or second-hand observation, consider a few examples of ship representations at the other end of the spectrum, in which the image is clearly separated from the prototype by several levels of dissociation:

- A porter holds a ship model on the Minoan Hagia Triada sarcophagus (Figure 20) (Long 1974). In this illustration we have a painting ... of a model ... of a ship.

- The Gurob ship-cart model copies a cultic boat on wheels, quite possibly a Dionysian ship cart, which, in turn, replicates a contemporaneous 13th or 12th-century BC Aegean-style galley, thus indicating three levels of separation (Figures 10 and 21b). ${ }^{11}$

- The Kinneret Boat (Sea of Galilee Boat) dates to the first century BC-first century AD (Figure 2a,b). The vessel was discovered on the western shores of the Sea of Galilee, Israel (Steffy 1990; Wachsmann 1990; 2009; 2015). A contemporaneous mosaic from the adjacent site of Migdal depicts a vessel like the Kinneret Boat, fully rigged, crewed, and with its mast and sail furled (Figure 2c) (Corbo 1978). This resemblance to the Kinneret Boat led me to erroneously conclude that the vessel in the mosaic represented an accurate contemporaneous depiction of the vessel type (Steffy and Wachsmann 1990). Ronny Reich (1991) notes, however, that there are other items arrayed around the 'boat' in the mosaic, which include a pair of Hellenistic/Roman-period scrapers (strigili), together with what Reich interprets as an ointment bottle (aryballos) attached to a ring with a chain, a drinking cup (kantharos), and a fish. In other words, the mosaic portrays a still life scene, including a model of one of the local vessels. Here again we have a situation that is analogous to that of the Hagia Triada Sarcophagus: in this case, a mosaic depiction of a model of an actual vessel. ${ }^{12}$

In some instances, artists plainly demonstrate that they did not fully understand the nautical details that they represent. For example, the Kenamun scene of Late Bronze Age Syro-Canaanite seagoing ships contains the most detailed known depictions of these vessels (Figures 4 and 5). During that period, the normative sail system consisted of a rectangular sail deployed between a yard and a boom (Wachsmann 1998, pp. 248-51, and there additional bibliography). This 'boom-footed rig' is clearly seen on the ships of Hatshepsut's expedition, in which it appears in both the raised and the lowered/furled positions (Figure 12). In this rig, the boom was secured to the mast. A number of lines, termed 'lifts', ran obliquely from the masthead to points along the yard and the boom. The crew set sail by raising the yard to the masthead. The lifts supported the yard in its lowered/furled position (Figure 12: ships at left), but when the sail was set/raised the yard's lifts served no purpose, and hung loosely in pendant arcs between the masthead and their various points of contact along the yard (Figure 12: ships at right).

11 On evidence linking the Gurob model to Dionysian cult, which apparently arrived in Egypt during the period of Sea People migrations, see (Wachsmann 2013, pp. 41-57, 59, 120-32, 203-4).

12 Similarly, but much farther afield, Kristian Kristiansen (2019) proposes that elements of Scandinavian rock art depict models. 
However, on several of the Kenamun ships, the yards' lifts attach at both of their extremities to the yard itself without connecting to the masthead, in a completely ineffectual manner (Figures $4 \mathrm{~b}$ and $5 \mathrm{~b}$ ). Elsewhere in the scene, a ship's yard is lowered in a position that would have resulted in the lifts being drawn taut in support of it (Figure 4a, lower left; Figure 5a, bottom center of scene). In this case Kenamun's artist connected the yard to the boom with lifts forming two pendant arcs in an impossible manner. I find it curious that the artist could confuse these details, as contemporaneous Nile ships employed this same rig, so that any Egyptian would have been familiar with its elementary details.

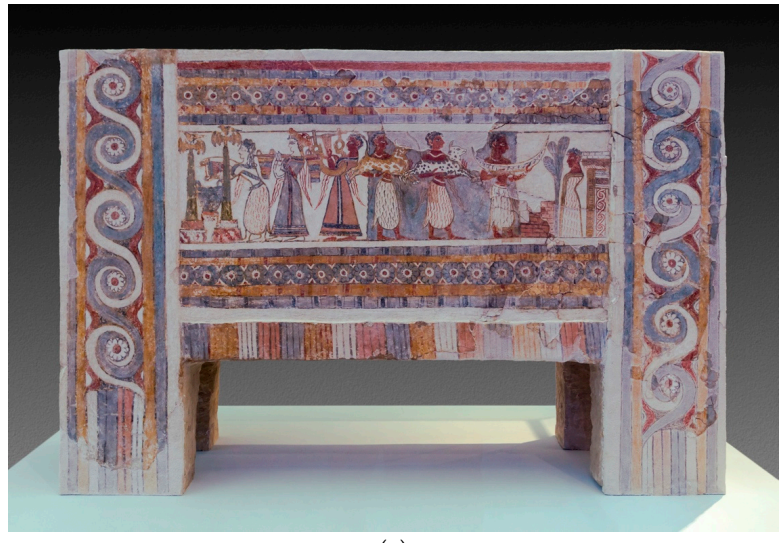

(a)
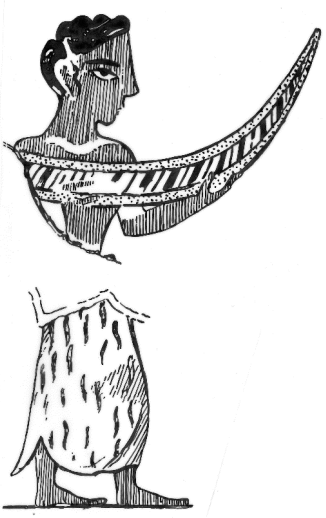

(b)

Figure 20. (a) The Hagia Triada Sarcophagus, (b) Detail of the mourner carrying a votive ship model on the Hagia Triada sarcophagus, Crete, ca. 1400 BC. (a) by Jebulon-Own work, CC0, https://commons.wikimedia.org/w/index.php?curid=40380234 (b) from (Wachsmann 1998, p. 102 figure 6.32) after (Evans 1964, I, p. 439 figure 316).

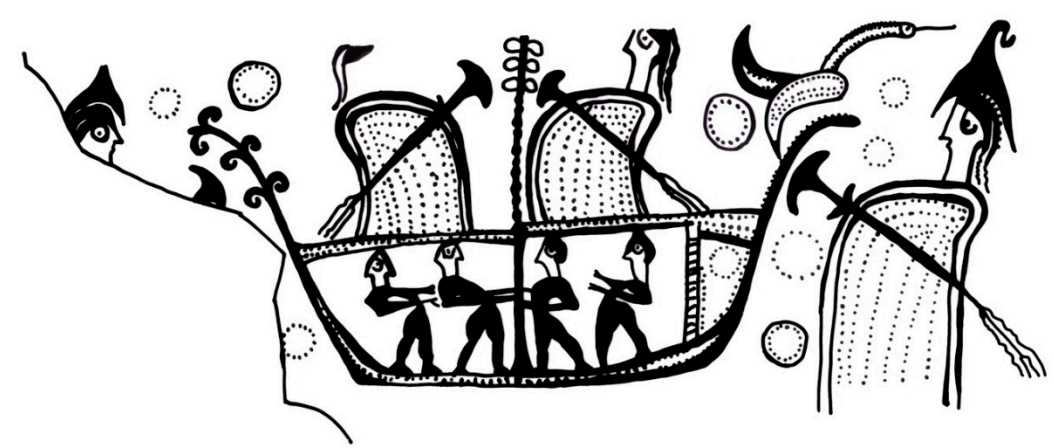

(a)

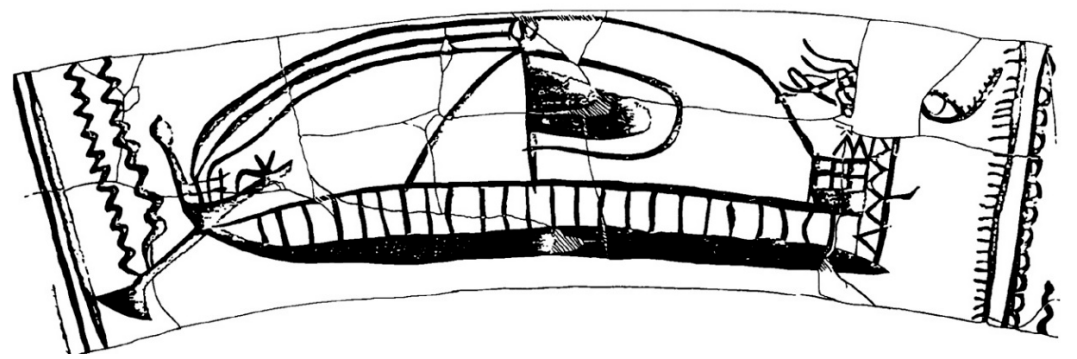

(b)

Figure 21. Two Mycenean representations that might reasonably depict the same ship type demonstrate the problem in creating typologies in an artistic environment in which images are spread through space and time and lack a unifying artistic style. (a) Ship depicted on a Mycenaean amphoroid krater from Enkomi, Tomb 3, Cyprus. Late Helladic IIIB. (b) Ship painted on a pyxis from a tomb at Tragana, near Pylos. Late Helladic IIIC. (a) after (Sjöquist 1940, figure 20: 3); (b) after (Korrés 1989, p. 200). Drawing (a): Megan Hagseth. 


\section{Modern Changes}

Beware of modern changes to ancient ship representations. When possible always examine the original ship depiction, or at least a photograph of it. This is important due to the possibility of encroaching error due to modern reconstructions. Early Egyptologists notoriously made repairs and changes to ancient boat models, such as arbitrarily reconstructing them, or rearranging the crews and ships' gear and even switching ship parts among models (Reisner 1913, p. XVI, 6 ns. 1-6; Doyle 1998, pp. 137-39; Wachsmann 2013, pp. 1, 4 figure 1.4, 5 figure 1.5-6, 91).

At times, reproductions are all that exist for a ship depiction. In the case of a Helladic/Sea Peoples style ship painted on an funerary urn from a cremation level at Hama, the excavators published only a painting and miniature line drawings, but no photographs (Ingholt 1940, pl. 22: 2; Riis 1948, pp. 48 figure 25, 97 figure 130: B, no. 112, pl. 12: C). I myself have replicated this image repeatedly (mea culpa) having been unaware until recently that the published images are in fact partially based on the modern reconstruction (Wachsmann 1998, p. 174 figure 8.19: B; 2013, p. 63 figure 2.33, passim). ${ }^{13}$

\section{On Ship Typologies}

Typologies represent one of the most important and difficult of tasks required of archaeologists. With some groups of ship representations there is, however, a distinct danger of over interpreting the evidence. We do well to consider the relevance of Davies (1930, pp. 29-30) comments regarding the interpretation of Theban tomb art:

The task cannot consist merely of collecting and arranging the items offered and then deducing the solution, as if by an operation in mathematics or chemical analysis.

... we long for exact historical truth and have so much to build on these deeply buried foundations, to remember how little it was the purpose of the ancient artist to record exact facts and still less to be of help to those who would come to his record without previous familiarity with its subject and its conventions. If we deal with his delightful, and, properly dealt with, most instructive pictures as if they were illustrations to an encyclopedia, we only delude ourselves and render his unintended services to the far future a diminution, instead of an increase of knowledge ... We must be sadly content to know nothing if there is nothing to know. We must be as ready to score above the line as below, admitting the large total which has been lost to us by the carelessness and impulsiveness of our partner (the ancient witness) as well as the positive gains we have made together.

Most Egyptian ship models lend themselves particularly well to typologies (Reisner 1913; Landström 1970; Jones 1990; Merriman 2011; Stephens 2012). Additionally, in cases in which a specific group of artists worked in a determined style to decorate pots with images of contemporaneous ships, a typology can be worthwhile. A study of war galleys on Attic Late Geometric-period ceramics, for example, has merit because a single group of painters, the Dipylon school, created these images in Athens over a period that probably did not exceed six decades (Morrison and Williams 1968, pp. 12-13, 18-37; Coldstream 2006, pp. 109-19; Basch 1987, pp. 162-63; Casson 1995, pp. 43-60). In this case, there exists a certain inherent conformity of artistic conventions and regional ship types-although even here not without significant differences(!)—that artists represented during a relatively short period. Other Geometric-period ship depictions demonstrate a similar cohesion of details as seen in the galleys appearing on Geometric-period Boeotian fibulae (Basch 1987, pp. 190-94; Basch and Artzy 1985, pp. 326-27 figure 13: A-G).

In some cases, however, typologies are ill advised. Such is the case with the Late Helladic/Sea Peoples' galley—-the very ancestor of those same Geometric ships. Depictions of these vessels come from

13 I intend to correct this error in an upcoming publication (Wachsmann in preparation). 
across the eastern Mediterranean world. Chronologically they span three centuries and the creators of these representations did not conform to any particularly artistic convention, but rather followed their own, often limited, artistic capabilities. In only a handful of instances can one demonstrate that more than one ship depiction came from the hand of a single artist (Wachsmann 1998, p. 155). Most of these representations come from the Late Helladic IIIC period (circa 1200-1075/1050 BC), an epoch noted for societal upheavals that contributed to insularity. In fact, perhaps the most notable feature of this corpus of ship imagery is the independence of styles in which artists represented them. At its extremity, the two ship depictions in Figure 21 may represent the same type of galley with an open rowers' gallery, discussed in detail below (Wachsmann 1998, pp. 135 figure 7.17, 137, 141 figure 7.28, 142-43). ${ }^{14}$ In situations such as this, a typology of such representations adds nothing and, in my view can be counterproductive (i.e., Wedde 1999). Such modern scholarly creations are particularly ill advised, because typologies are so easily, and so often, quoted by other scholars seeking expertise on the subject. In such cases, it seems preferable to limit discussion to listing the major characteristics of these craft as seen in the iconography while avoiding categorizing the representations themselves (Wachsmann 1998, pp. 155-58).

\section{Which Way Forward?}

Sometimes crude ship representations lack sufficient detail to even distinguish a vessel's bow from its stern. ${ }^{15}$ A graffito of a ship on a Late Helladic IIIC stirrup jar from Asine has a long horizontal line extending from its left side (Figure 22). Some scholars consider the projection an early nautical ram and, therefore, determine that the ship faces left, while others believe the ship to be facing right (Left: Kirk 1949, p. 117 figure 5; Morrison and Williams 1968, p. 10 no. BA.3. Right: Casson 1995, p. 32 figure 29; Bass 1972, p. 22; Basch 1987, pp. 146-47 figure 309). ${ }^{16}$ In this case the authors focus on whether the horizontal line is a quarter rudder strung out aft of the vessel or a bow projection.

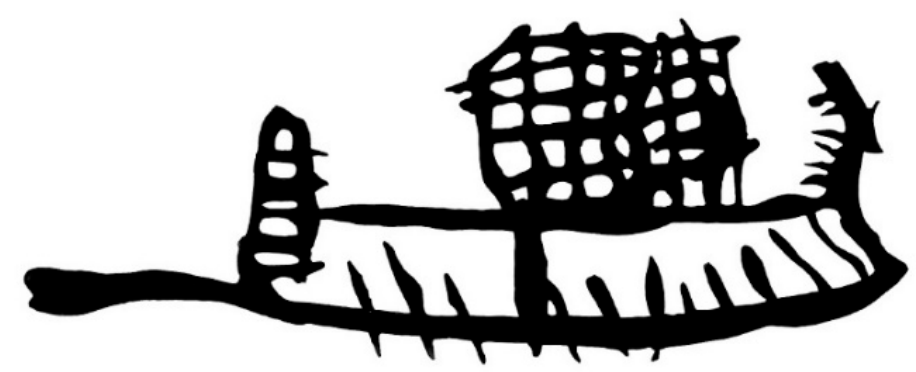

Figure 22. Ship on a vase from Asine, Greece. Late Helladic IIIC. From Wachsmann 1998, p. 139 figure 7.22) after (Casson 1995, figure 29).

In such cases, if the vessel is under sail, consider in which direction the sail is set. As Williams himself notes, the thick vertical line bisecting the hull must represent the mast. If so, then the vessel's sail is swelling to the right and the bow lies in that direction, a conclusion supported by additional evidence (compare the billowing sail on the galley in Figure 21b) (Wachsmann 1998, pp. 139 figure $7.22,140)$. If they are to function, however, masts cannot be stepped aft of amidships, which seems to be the case here if this interpretation is correct. Indeed, this would be a problem if we were dealing here with an actual ship. But such is not the case: this is a representation of a ship, one in which the artist chose to indicate the billowing of the sail without undue concern as to where exactly the mast would have been stepped in reality.

14 See below, Section 9. Corpus Delecti.

15 On determining the directionality of Early Cycladic long ships, see below, Section 8. Cultural Continua.

16 Earlier Lucien Basch (1975, pp. 201, 202 figure 2) had identified the left end as the bow. 
A similar problem exists concerning a ship incised on a stele dated to the Late Cypriot III period (circa 1225-1050 BC) from Enkomi (Figure 23a) (Wachsmann 1998, pp. 142 figure 7.29A, 143-144). This ship can be explained as a Helladic style warship of the period if it faces right: but does it (Wachsmann 1998, pp. 130-58; Wachsmann 2013)? The sail, if represented by the lines in Figure 23b: 2-3-6, appears to be billowing to the left, which would indicate that the ship faces left. Here an informed knowledge of the ship type and its rig aids in resolving the issue.
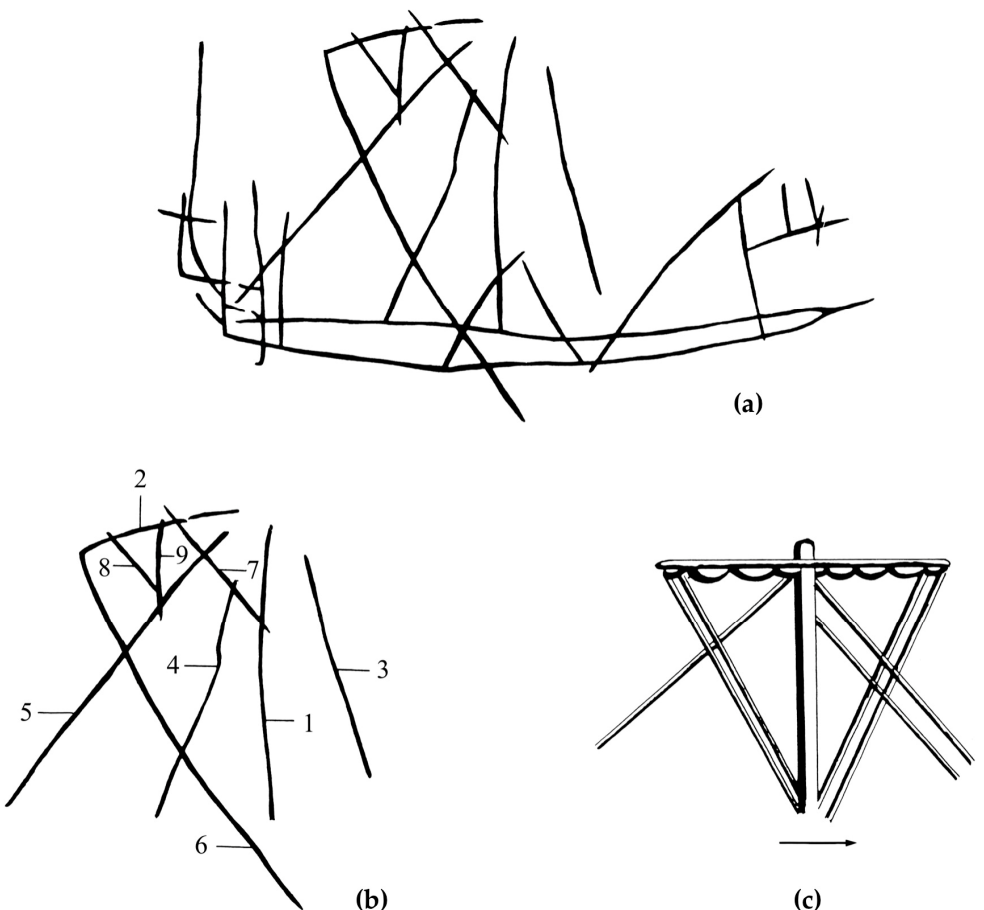

(c)

Figure 23. (a) Graffito of a ship on a stele from Enkomi, Cyprus. Late Cypriot III. (b) The ship's rigging. (c) Detail of a Phoenician ship's brailed rig with the sail furled to the yard, ca. 700 BC. After (Wachsmann 1998, p. 142 figure 7.29).

This graffito dates to the time of the brailed sail, which first appears towards the end of the Late Bronze Age (Figures 7a and 15-18) (Casson 1995, pp. 70, 234 no. 42, 259 no. 3, figures 72, 81-82, 89, 90, 95-97; Vinson 1993; Wachsmann 1998, pp. 251-54; Whitewright 2018). The brailed sail did away with the boom of the earlier rig and allowed the crew to control the sail by pulling on lines termed brails that ran from the foot of the sail over the yard through (brailing) rings sewn to the forward side of the sail. ${ }^{17}$ A crew could configure the sail by controlling the brails, rather like raising or lowering a modern Venetian blind. This permitted sailing to windward, something impossible with the earlier boom-footed rig (Cariolou 1997). To take in sail, the crew hauled on the brails. When furled, the sail collects in bunches beneath the yard (Figures 17 and 23c). This same brailed sail allowed for the dramatic expansion of sea routes at the outset of the Iron Age (Wachsmann 1998, p. 331).

With the brailed rig in mind, now reconsider the sail on the Enkomi ship. The lines comprising the mast and rigging can be reasonably explained for a ship facing right. Thus, in Figure 23b, line 1 must represent the vessel's mast, 2 the yard, 3 would then stand for a single forestay, 4 a halyard or a brail, 5 a backstay, and 6 a brace. The triangles formed by lines 2, 8 and 9 and lines 2, 7 with (mast) 1

17 Herodotus (Histories 2.36.4), writing in the fifth-century BC, states that the Egyptians alone had the curious habit of running their brails on the 'inside', that is the after side, of their sails (Basch 1978, pp. 115, 116 figure 28-29, 118; Casson 1995, p. 234 no. 42; Vinson 1993, p. 135 no. 11). 
then crudely represent the hanging bunches of the vessel's brailed sail in the furled position (Figures 17 and 23c). ${ }^{18}$

\section{Cultural Continua}

In ship evolution and in the development of ship-related accoutrements and customs, one can sometimes discern a 'cultural continuum'. Certain elements, or even nautical customs, that, although they evolve and transform over time, also remain true to an original concept. These examples of continuity can last for centuries, and in some cases millennia (see, for example, Whitewright 2018). When such a phenomenon can explain a research question, one should not deviate from it, as it represents the simplest resolution. ${ }^{19}$ The following two cases-the directionality of Early Bronze Age Cycladic longships and the identity of Late Bronze Age/Geometric-period stem and stern devices-demonstrate this point.

The earliest representations of Aegean seagoing vessels appear in the Early Cycladic period (third millennium BC). The best known two-dimensional representations of these vessels decorate a series of remarkable cultic artifacts commonly termed 'frying pans' due to their shape, not purpose (Figure 24) (Coleman 1985; Papathanassoglou and Georgouli 2009). While distributed across Greece, the Aegean and Turkey, only the frying pans from the Cycladic island of Syros bear ship representations, all seeming to depict the same type of vessel. In these two-dimensional representations these watercraft, commonly termed 'Cycladic long ships', appear to be long and narrow, with one high extremity and the other low. An outboard-facing fish totem sits atop the high end while the low extremity of each vessel bears a horizontal projection continuing the lower line of the hull. Rows of parallel lines appear along the sides of each hull.

Scholars have vigorously debated which extremity of these vessels represents the bow, and which the stern (Johnstone 1973; Casson 1975; Wachsmann 1980; 1998, pp. 73-74; Johnston 1982; Basch 1987, pp. 84-85). This debate continues (Guttandin 2009; Guttandin et al. 2010, 2011; Wachsmann 2011b).

For over a half century following Sir Arthur Evans' discovery of the Minoan culture in nearby Crete at the birth of the 20th century, little new evidence emerged for clarifying the directionality of the Cycladic vessels. The available visual corpus consisted of ships engraved on thumbnail-sized seals and sealings, a few poorly-made models and the Hagia Triada Sarcophagus, each with its own limitations (Figures 11, 20 and 25) (Marinatos 1933). Then Colin Renfrew (1967) published a remarkable trio of third millennium BC lead ship models, now in the Ashmolean Museum, from the Cycladic island of Naxos. The models clearly replicate, but in three dimensions, the long-ship type appearing on the Cycladic frying pans and confirm that the prototype vessels indeed had long and narrow dimensions (Casson 1995, p. 41). The best preserved of the models has a beam-to-keel ratio of 1:14 (Figure 26).

As paddlers must be situated immediately adjacent to the sides of a vessel, paddling requires less inboard space than rowing, which makes paddling the normative manner to propel narrow vessels (Figure 27). Thus, the models' tapered proportions indicate that the rows of parallel lines on the frying pan craft must represent paddles rather than oars (Basch 1987, p. 84; Wachsmann 1995, pp. 10, 13-14). These models lack the horizontal projections that appear on the low extremity of the frying pan ships. Rather, the low extremities end in a sheet of lead that folds transom-like into the stern.

18 See also figures below, in Section 8. Cultural Continua.

19 See above, Section 2. Shaving with Occam's Razor. 

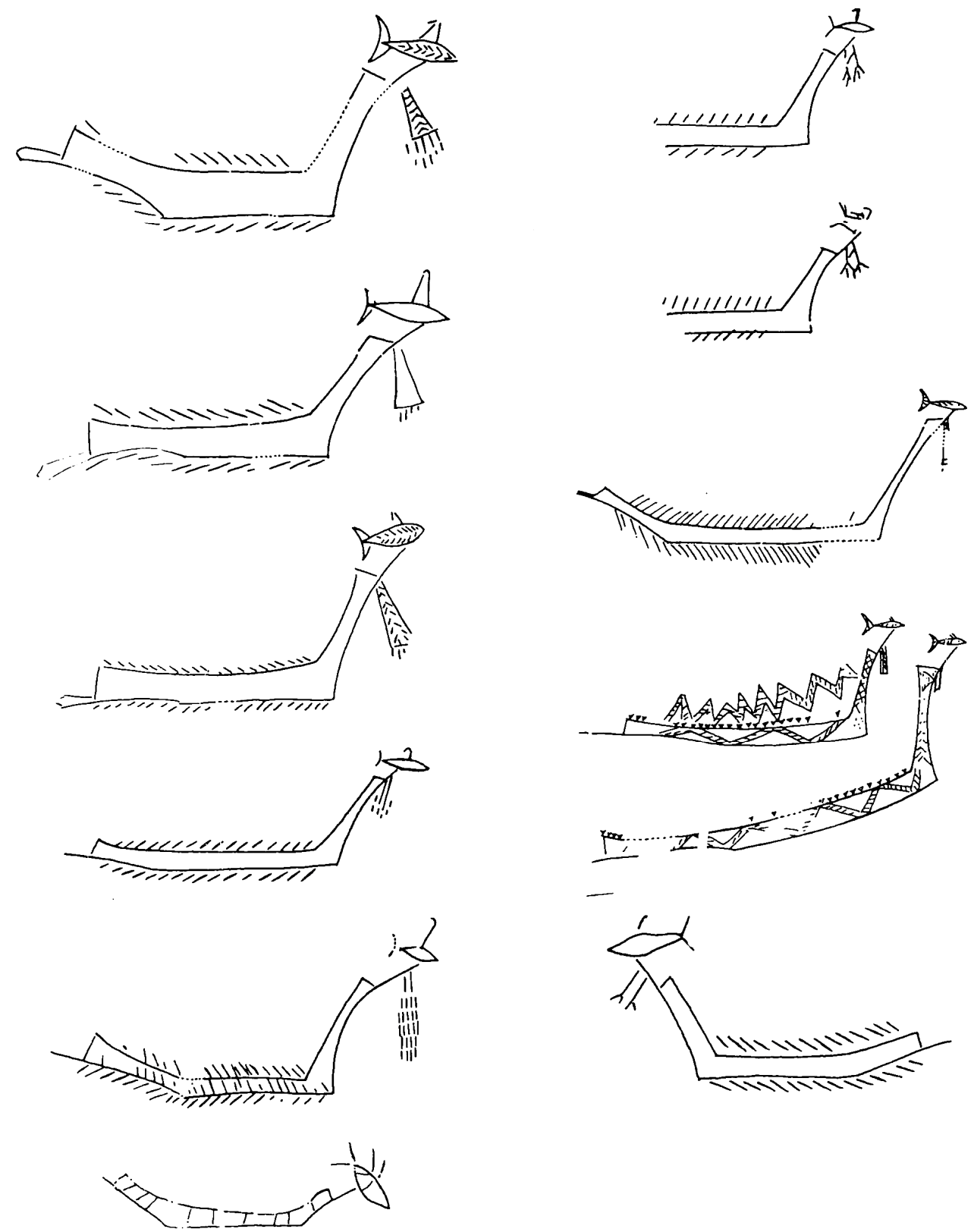

Figure 24. Ships incised on Cycladic 'frying pans'. Early Cycladic II (2650-2500 BC). From (Wachsmann 1998, p. 72 figure 5.4). 

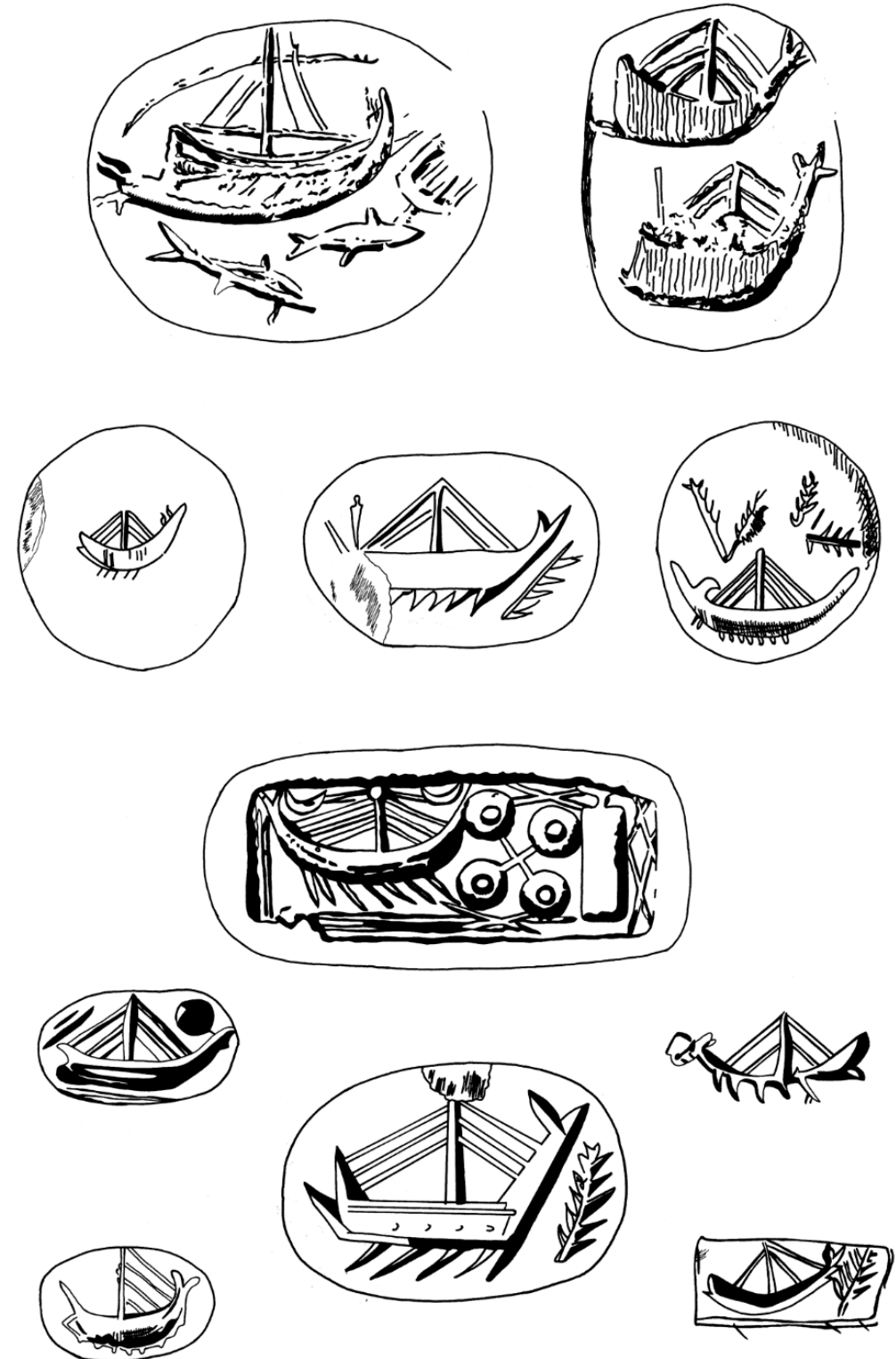

Figure 25. Ships incised on Early Minoan III seals. From (Wachsmann 1998, p. 100 figure 6.29).

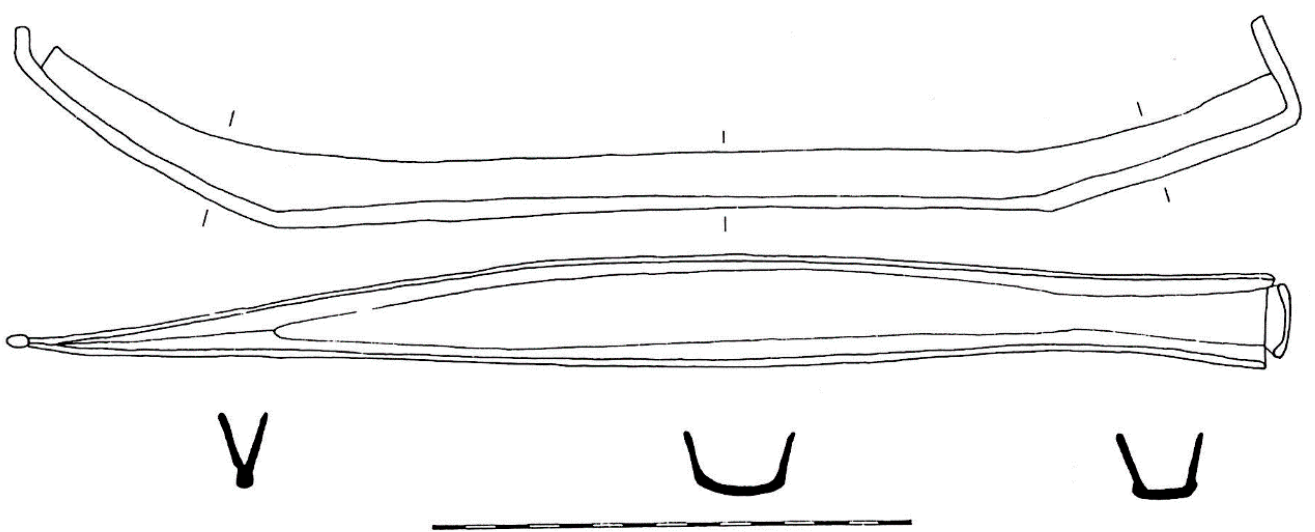

Figure 26. The best preserved of the three Naxos lead ship models. Third millennium BC. From (Wachsmann 1998, p. 72 figure 5.2). 


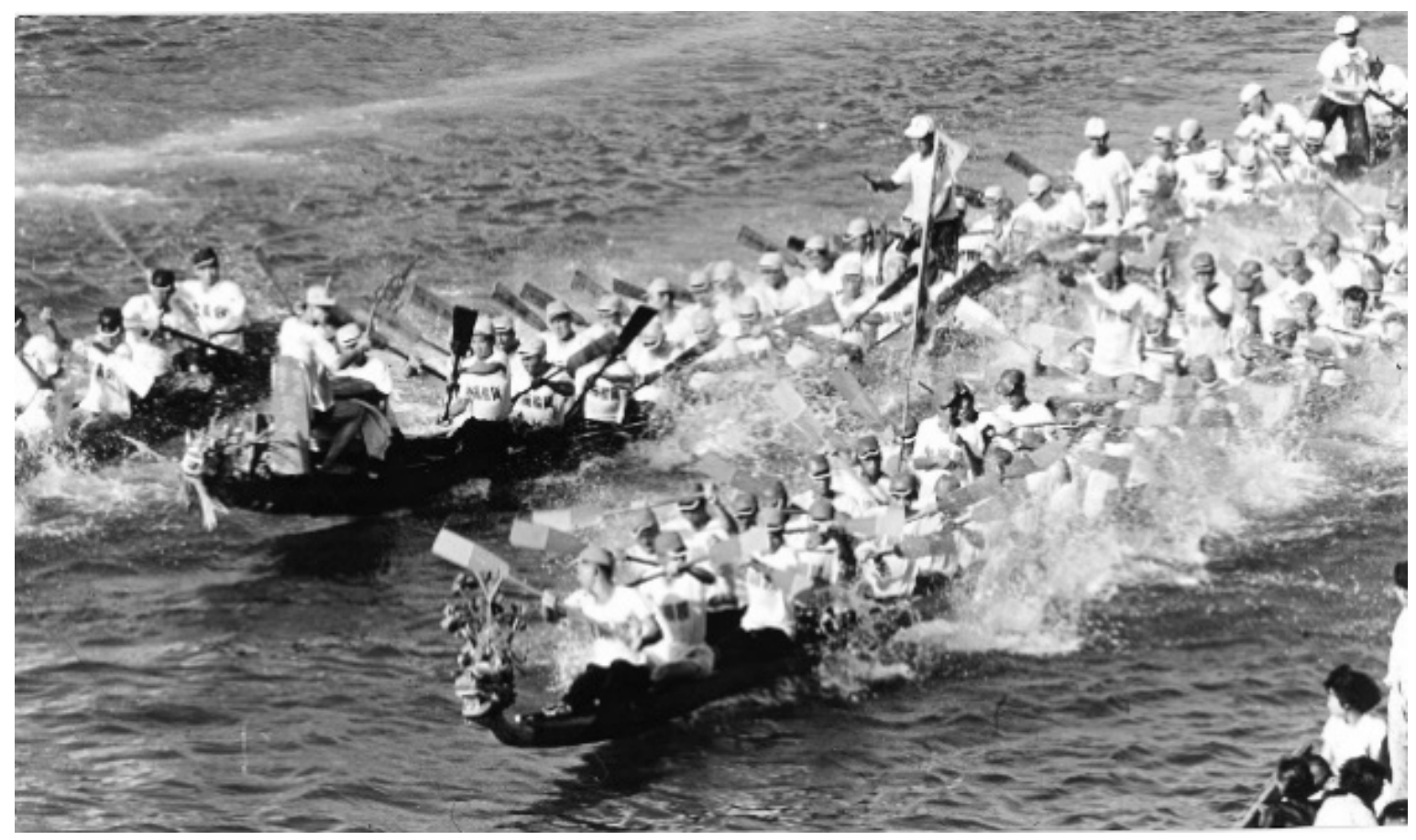

Figure 27. Paddling is the normative method of propulsion for vessels with narrow hulls. Here paddlers propel slender dragon boats during a race. Hong Kong. From (Wachsmann 1998, p. 110 figure 6.47).

This absence of the horizontal extension on the models raises two possible explanations: either the device was not an integral part of the vessel's structure, being only attached when mandatory to accomplish its function, or some ships of this type were constructed with this projection while others were not. The latter possibility can be likened to the case of keel extensions on the bows of Late Helladic/Sea Peoples' galleys: some had the extensions while others did not (compare Figures 10, 21b, 22, 23a [With bow extension] with Figures 17, 18, 21a [Without bow extension]) (Wachsmann 1998, pp. 157-58).

The status quo dramatically changed, however, in 1972 when Spiridon Marinatos, excavating at Akrotiri on the Cycladic island of Thera, discovered a structure that he termed the 'West House', which contained a series of polychromatic frescoes bearing nautical motifs (Marinatos 1974, pp. 19-31, color pls. 2, 4, 6, 9; Basch 1987, pp. 117-32; Morgan 1988, pp. 121-45, 150-54, color pls. A, C; Doumas 1983, pp. 48, 49 figure. 6, 82-88, 105-106, color plates II, X-XI, XIV; 1992, pp. 45-97; Wachsmann 1980; 1998, pp. 86-122). The site and the frescoes had been buried in the wake of Thera's eruption circa 1628 BC. While these frescoes derive from an indigenous Cycladic culture, it had clearly been highly influenced by contact with the Minoans. In truth, the ships appearing in these frescoes show such similarities to what can be gleaned from the thin gruel of evidence for Minoan vessels that it is preferable to inclusively term these ships as being of Minoan/Cycladic origin. There may have been differences between Minoan ships and those appearing in the West House frescoes, but from this distance in time and with the evidence available, it truly would be unwise to attempt to differentiate between them.

The Miniature Frieze on the south wall of the West House's Room 5 portrays a naval regatta or procession (Figure 28). A second scene in the Miniature Frieze depicts ships of the same type as the processional ships, but lacking the festive decorations, beached along a rocky shore, and with oars adrift in the water (Basch 1987, pp. 131-32; Morgan 1988, pp. 150-54, color pl. A; Doumas 1983, color plate XIV; 1992, pp. 58, 60-63; Wachsmann 1998, pp. 88-91, 113-17). Several dead bodies float in the surf and nearby soldiers, apparently disembarked from the ships, march inland. 


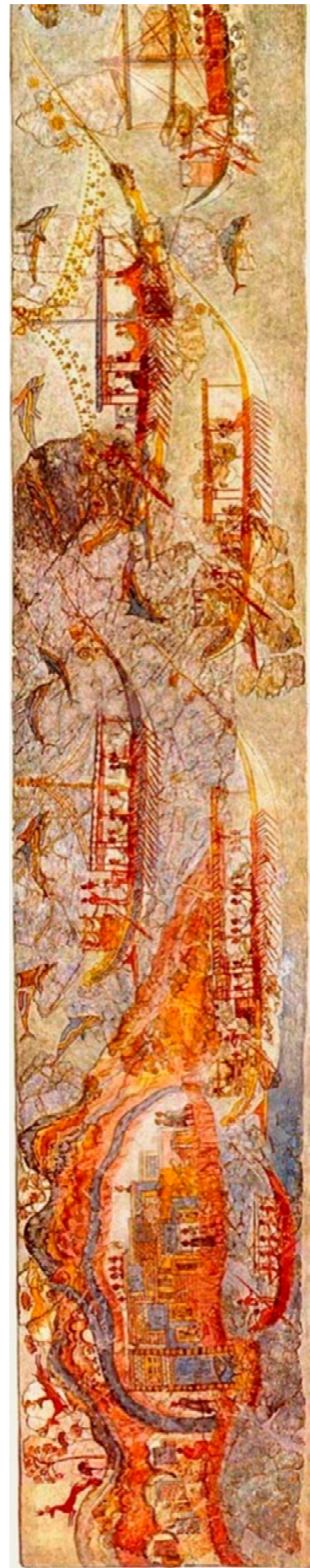

(a)

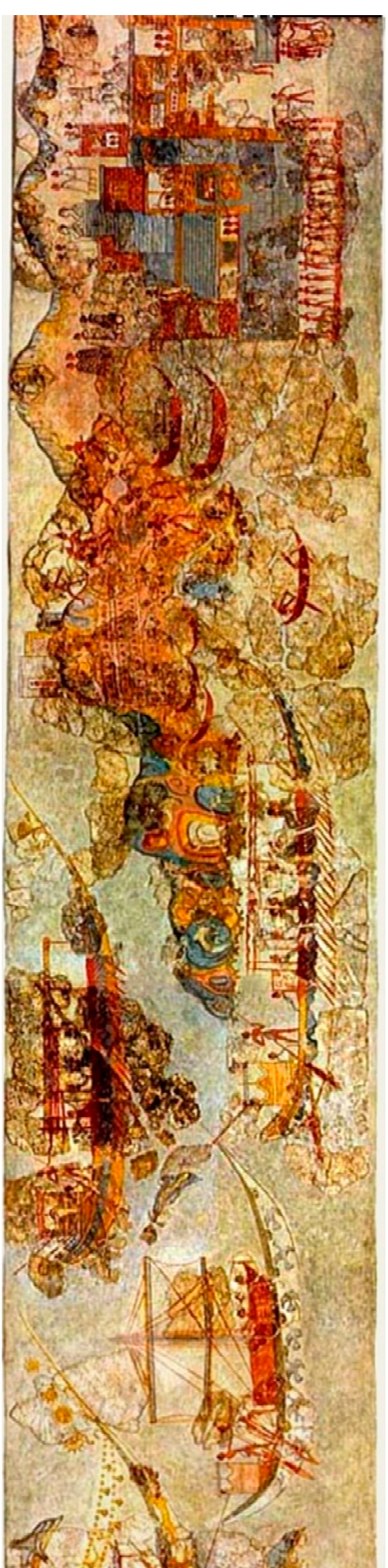

(b)

Figure 28. The waterborne procession in the south Miniature Frieze. Courtesy Wikimedia Commons. By pano by smial; modified by Luxo; Image: AKROTIRI SHIP-PROCESSION-FULL PANO.jpg, Public Domain, https://commons.wikimedia.org/w/index.php?curid=1568965. Used with permission.

Significantly, the six ships participating in the procession have several pertinent unifying characteristics (Figures 28 and 29a):

- They are highly decorated and carry ornamented bowsprits missing on the functional ships.

- While the processional ships have masts and sails, in all cases, the sails, and sometimes also the masts, have been lowered. 
- Perhaps most surprisingly, the ships move under paddles, not oars. The awkward manner in which the paddlers strain, bending over the sides of the hull, makes it abundantly clear that paddling was not the accustomed manner of propulsion for these vessels (Figures 29a and 30). Furthermore, in the same scene, a vessel accompanying the procession moves under oar, which indicates that the Therans knew both forms of propulsion well (Figure 28a [far left of scene] and Figure 31).

- However, for the present discussion, the most significant factor is that each of the processional ships carries a horizontal device under its stern (Figure 29b). This extension, repeatedly depicted in great detail in the fresco, appears to be clearly lashed to the sterns of the processional vessels. Those not taking part in the regatta lack the device.

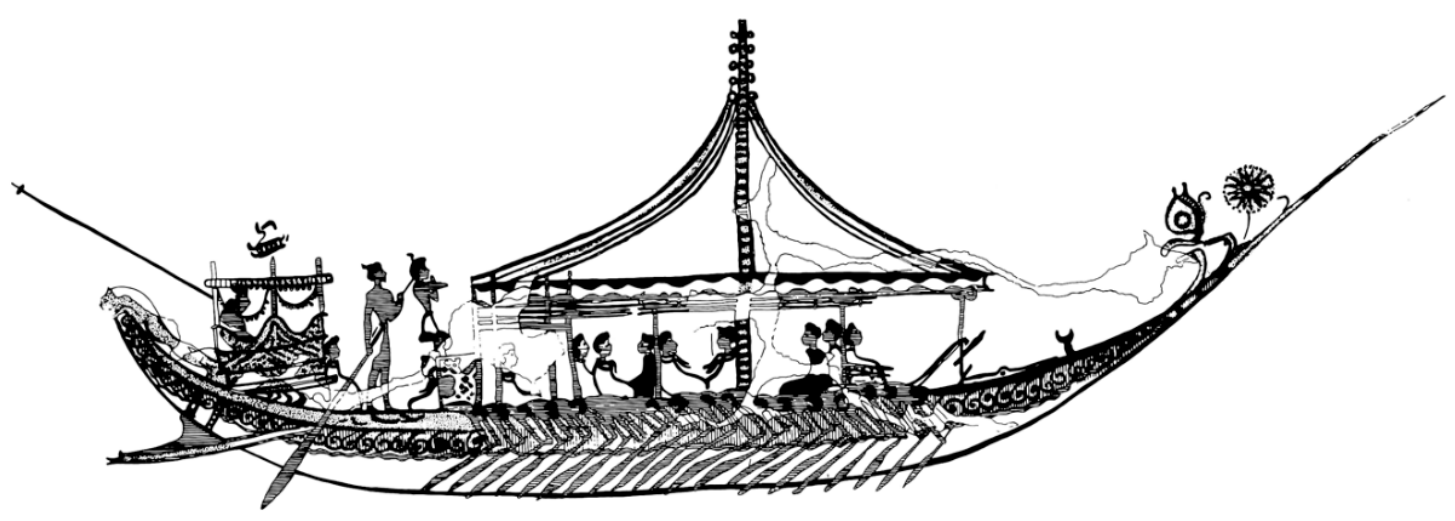

(a)

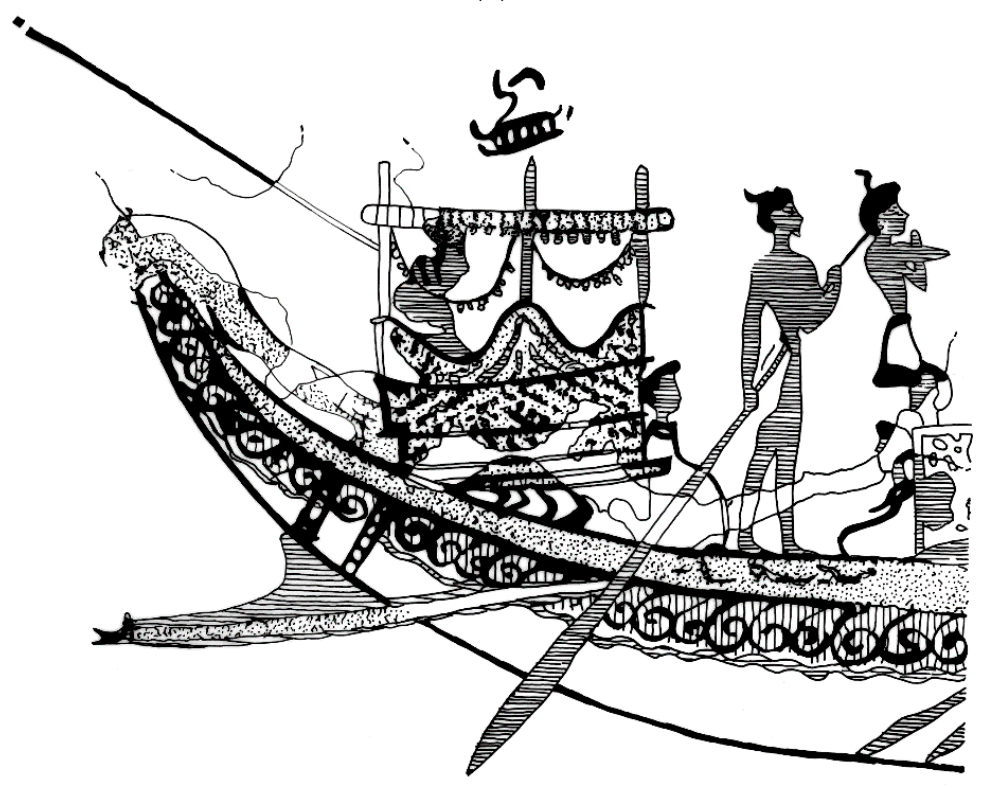

(b)

Figure 29. (a) Line drawing of the best preserved of the ships taking part in the waterborne procession portrayed in the Miniature Frieze, West House, on Thera. (b) Detail of the stern of the same ship, with its attached horizontal projection. From (Wachsmann 1998, pp. 92 figure 6.13, 93 figure 6.14) after (Marinatos 1974, color plate 9). 


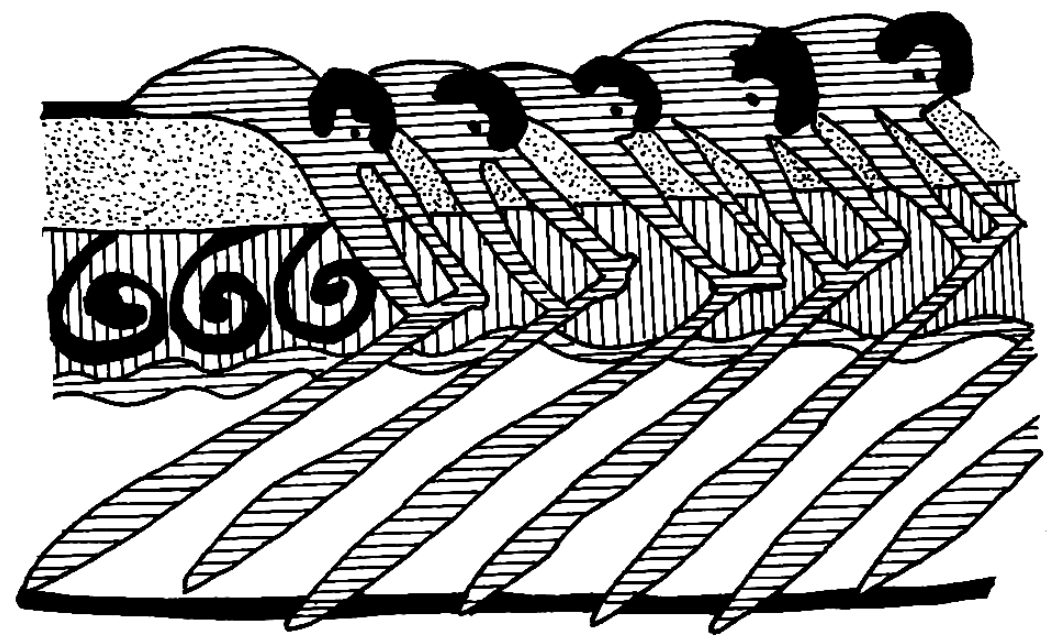

Figure 30. Paddlers on a processional ship in the Miniature Frieze bend over to complete their stroke. Miniature Frieze, West House, Akrotiri, Thera. From (Wachsmann 1998, p. 106 figure 6.42) after (Marinatos 1974, p. 51 figure 6).

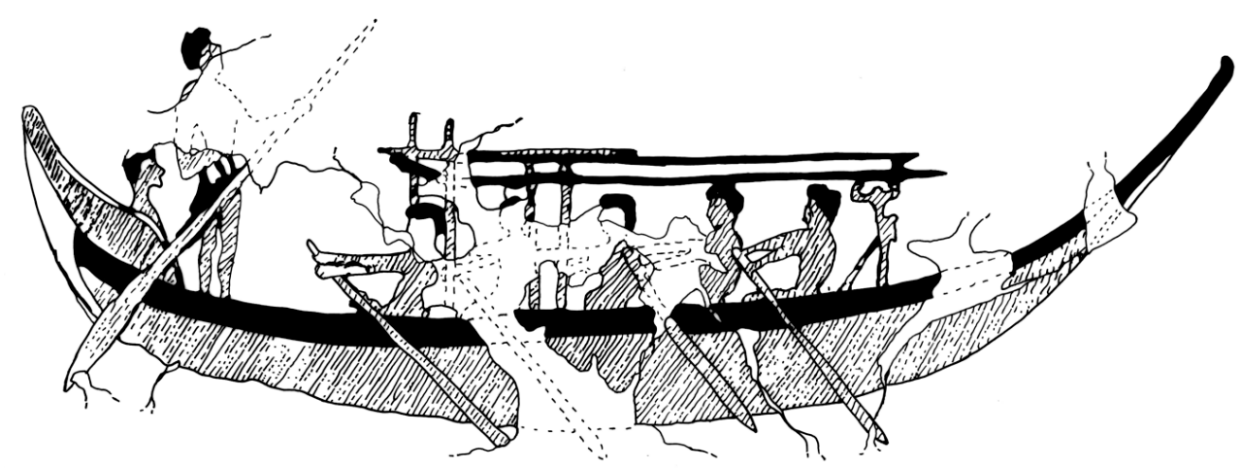

Figure 31. The rowed ship accompanying the procession. Miniature Frieze, West House, Akrotiri, Thera. From (Wachsmann 1998, p. 93 figure 6.16) after (Doumas 1983, p. 121 figure 20).

Lionel Casson (1975, p. 7) proposes that the processional ships were either old vessels or, alternately, contemporaneous ones employed in an archaic manner:

Now, at Athens in Classical times it was the practice to send the embassy to the annual spring festival of Apollo at Delos in a vessel that was so old fashioned that people were able to say it was the one in which Theseus had sailed to Crete. Why not a similar situation here? That the six ships are an archaic style of craft called into use for a special religious ceremony? Either that or they are current models that are deliberately being handled in archaic fashion, as demanded by the ceremony in which they take part?

Following Casson's lead, we might ask the following question: if the ceremonial ships represent contemporaneous vessels emulating older indigenous craft, then which culturally-related earlier craft are they emulating? The answer, of course, is self-evident. The Theran ships' archaizing attributes all hark back to the third-millennium Cycladic long ships, which were decorated, lacked sail, were propelled by paddlers and they had a detachable horizontal stern projection (Figures 24 and 26).

Thus, regarding the directionality of the Cycladic long ships, we can confidently determine that on these vessels the high end represents the bow, and that the low end, with its horizontal extension, represents the stern by identifying a localized cultural continuum (Wachsmann 1980; 1998, pp. 86-99, 105-22; 2011b).

Another example of a cultural continuum relates to the decoration of stem and sternposts on Mediterranean watercraft. Statues of birds, bird heads, and particularly the beaks of water birds, have 
displayed a remarkable resilience as ornaments on Mediterranean seacraft. These devices are perhaps best known as symbols on Roman-period merchant ships (Figure 32). However, it transpires that bird-head decorations, and sometimes even statues of birds, also served as a standard decoration on warships of the Late Bronze Age, the Iron Age, the Classical period, and later (Wachsmann 1996; 1998, pp. 177-202; Lenz 1998).
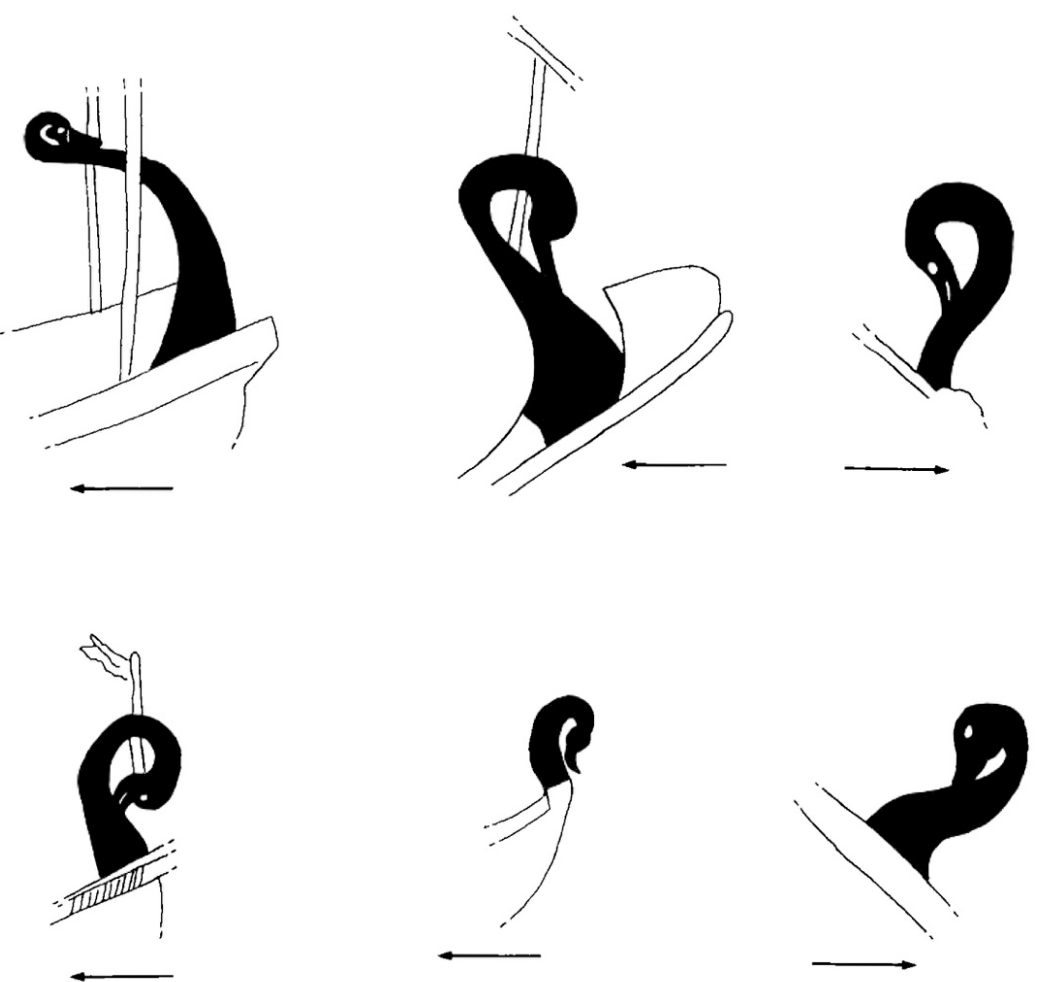

Figure 32. Bird-head stern ornaments on merchant craft in the first and second centuries AD. After (Wachsmann 1998, p. 178, figure 8.24).

These bird devices have an exceptionally long and fascinating history. They first appear on Helladic vessels or on those that belong to the Sea Peoples (Figures 17, 18, 21 and 33). Similar birds commonly appear on Mycenaean and Philistine pottery (Furumark 1941, pp. 250-52, 253 figure 30, 254, 255 figure 31 [nos. 36-52]; Benson 1961, 1975; Dothan 1982, pp. 198-200, 201-2 figures 61-63, 203; Meiberg 2011, pp. 47-51, 54-69, 81-90, 99-112, 126-44, 162-65, 182-87). ${ }^{20}$ Most remarkably, we bear witness to a repeating cycle in which the bird head first appears in its natural form and then cycles through stylized, and then completely abstracted, forms of a bird head, ending with the bird's head and beak transforming into little more than a complex curve.

20 Often these ships depict bird heads with upturned beaks, a feature unparalleled in birds appearing in Aegean or Philistine art (Figure 21b). The upturned beak may represent a central European Urnfield influence (Wachsmann 1998, p. 180 figure 30: A). 

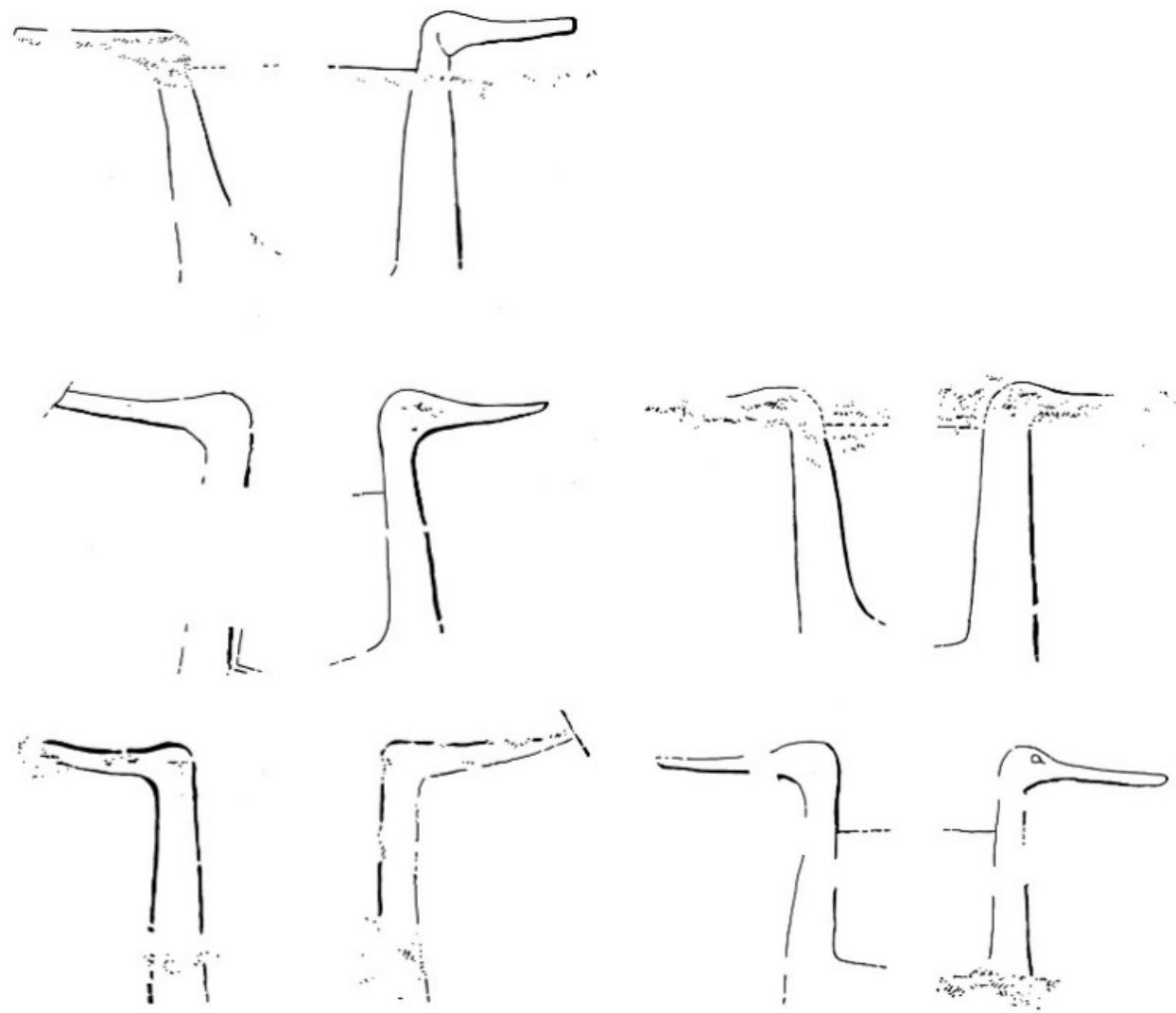

Figure 33. Outboard facing bird head devices on the stem and sternposts of the five depictions of a Sea Peoples' ship at Medinet Habu. Note that only the bow (right) bird-head protome of ship N.5 (bottom right) has a carved eye. Ramses III. After (Wachsmann 1998, p. 177 figure 8.23) derived from (Epigraphic Survey 1930, pl. 39). Courtesy of the Oriental Institute of the University of Chicago.

Stern devices in the shape of bird heads painted on three Cypriot jugs dating to the sixth century $\mathrm{BC}$ serve as a key to understanding the vast variety of forms in which bird heads can be depicted (Karageorghis and Gagniers 1974, pp. 122-23 nos. XI: 1-3). An entirely natural bird head, complete with eye and facing inboard, tops one vessel's sternpost (Figure 34a). In a second ship (b), the eye disappears, and the head becomes stylized, but it remains differentiated from the beak. However, on a third craft (c), the bird head and beak devolve into little more than a sinuous curve. Even if this progression results solely from the abstraction by the artist(s) who created these images, the bird heads nevertheless demonstrate a clear and obvious evolution. This cycle-natural, stylized, and abstract-repeating on ships in the ancient Mediterranean creates a clear cultural continuum of Mediterranean ship ornamentation (Wachsmann 1996; 1998, pp. 177-97; 2013, pp. 78 figure 2.48, 79). Additionally, a strong argument can be made for bird-head devices that serve as the immediate precursors of two devices-the volute and the aphlaston (Appendix A) - that later decorate the sterns of Greek and Roman warships: (Wachsmann 1996, pp. 544-45; 1998, pp. 189-90, 191 figures 8.56: A, C-D, 8.57, 192 figure 8.59: B-C). 


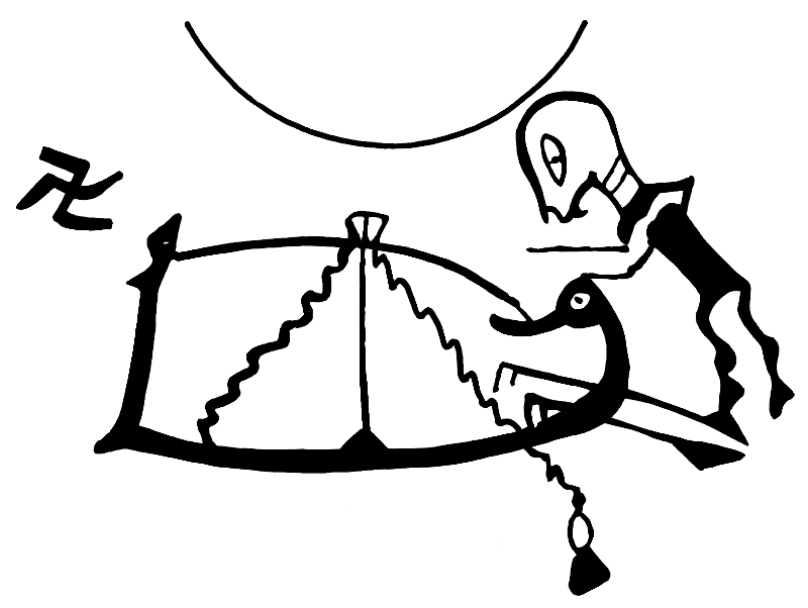

(a)

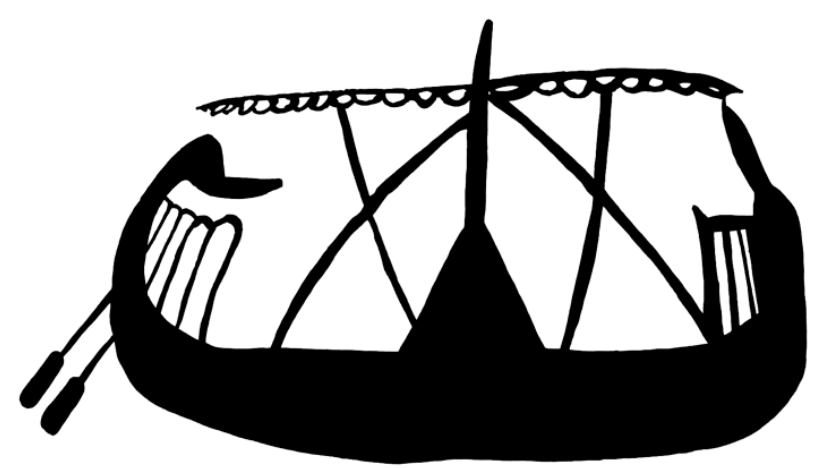

(b)

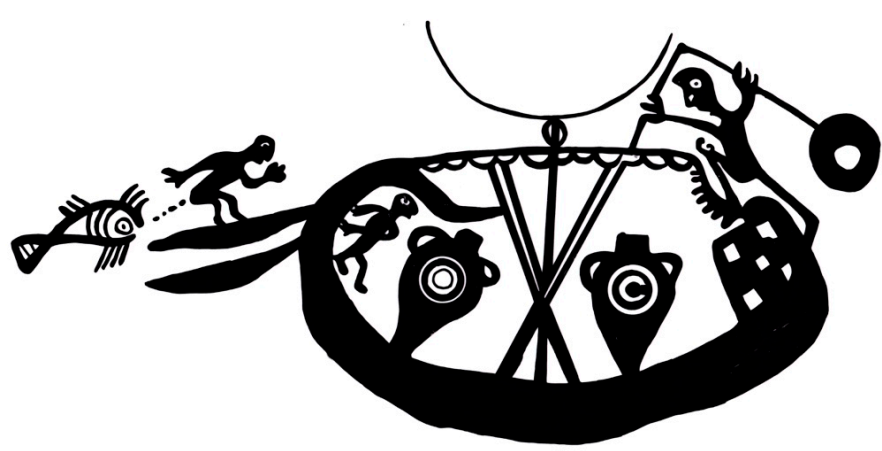

(c)

Figure 34. Ships appearing on three Cypriot jugs dating to the seventh century BC demonstrate the progressive mutation of a naturalistic bird head and beak, with eye (a) to stylized (b) and then abstract (c) versions. From (Wachsmann 1998, p. 183 figure 8.41) after (Karageorghis and Gagniers 1974, pp. 122-23 nos. 11: 2, 3, 1). Drawing (c): Megan Hagseth.

However, other identifications have been proposed for these stem and stern devices. Assaf Yasur-Landau (2010) studies the stem ornaments seen on Late Helladic ship depictions. He discusses, and dismisses, the possibilities that the devices represent birds, griffins, or horses, and concludes that, on Late Helladic IIIC ships, these items are best interpreted as "sea dragons". To support this argument, Yasur-Landau compares these bow decorations to stern devices on Minoan cultic boats that predate the Late Helladic IIIC by several centuries, as well as to a depiction of a dragon-like creature, which appears on a pictorial vase from Ashkelon, but notably not as a ship decoration (Evans 1964, IV: 
II, pp. 950-53; Wachsmann 1998, p. 112 figure 6.52 [also p. 113 figure 6.54 for depictions of similar creatures in the sea in Minoan art]; Stager and Mountjoy 2007).

In a similar vein, Homer (Iliad 18.3, 19.344) describes his ships having "upright horns". Observing Geometric-period warships, roughly contemporaneous to the structuring of the Homeric epics, one well understands the appropriateness of that particular epithet (Figure 35) (, p. 45, pls. 1: e, 2: a, c-d, 3: b, 4: a, c [i-ii d-e]B124-arts-588633; Basch 1987, pp. 166 figures 334-336, 171 figures 349-352, 172 figure 353, 173 figure 357, 174 figure 360-361, 175 figure 362, 176 figure 367, 177 figures 371-372, 178 figure 374, 187 figure 393, 188 figures 394-395, 189 figures 396-397; Casson 1995, p. 45 no. 16, figures 30, 62, 65-68, 72, 74; Wachsmann 1998, p. 186; Lenz 1998; Mark 2005, pp. 97-98, 102, 104). Michael Wedde (2002, p. 858) takes this epithet as indicating that the curving appendages visible on these vessels represent horns.
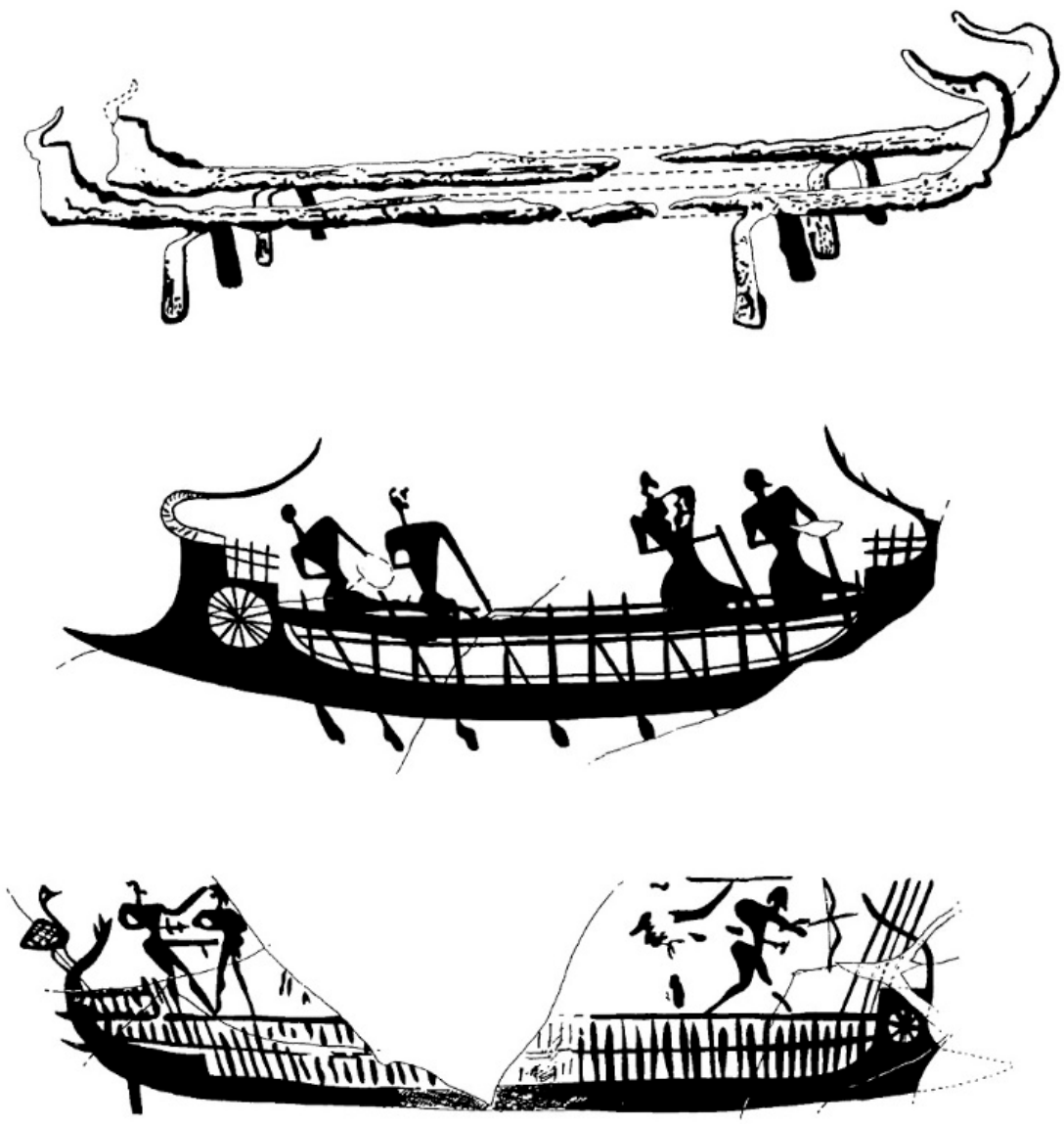

Figure 35. Compound-curve shaped ornaments (stylized and abstract bird heads) topping the stem and sternposts of Geometric period (eighth century BC) warships. After (Wachsmann 1998, p. 188 figure 8.50).

What is the simplest explanation (Occam's Razor) for the devices on Helladic and Geometric-period ship representations? Hypothetical interpretations that would have sea monsters on Helladic ships, or horns appearing on Geometric galleys, have no antecedents and no descendants in Bronze and Iron Age Mediterranean ship iconography. If correct, these devices would have to appear out of nowhere and then immediately return there. Again, in this case, bird heads, as part of a well-documented cultural continuum, should be preferred.

\section{Corpus Delicti}

The manner in which human figures relate to a ship representation can occasionally contribute significant details regarding the prototype vessel's structure, as seen in Ramses III's naval battle relief 
at Medinet Habu. The relief today is in a sad state when compared to how it must have appeared in its heyday. Originally, the wall would have been plastered, carved, and painted. Today, no traces remain of the thick layers of plaster that had been used to smooth the wall's surface and make corrections, nor of the paint (Nelson 1929, pp. 22-23). This represents a significant loss to our knowledge, as Egyptian artists did not differentiate between the carved and painted detail in this art form. We can infer the dramatic loss of information that vanished with the paint from the following description by Harold $H$. Nelson (1929, p. 22) of another battle scene, this one against the Libyans (Tjemhu), in which the paint had survived at Medinet Habu (Figure 36):

Here, in the upper portions of the relief, even the water-color paint is unusually well preserved, and we find that the bare sculpture has been extensively supplemented by painted details distinctly enriching the composition. The colors of the garments worn by the Libyans clearly stand out. Between the bodies of the slain as they lie upon the battlefield appear pools of blood. The painter has suggested the presence of the open country by painting in wild flowers that spring up among the dead. Moreover, it is apparent that the action takes place in a hilly region, for streams of blood run down between the bodies as the enemy attempt to escape across the hills from the Pharaoh's pursuing shafts. The details of the monarch's accouterments are indicated in color, relieving him of the almost naked appearance that is often presented by his sculptured figure when divested of its paint. It is not infrequent to find such details as bow strings or lance shafts partly carved and partly represented in paint. The characteristic tattoo marks on the bodies of the Tjemhu are also only painted in pigment. When all of these painted details have disappeared, though the sculptured design might remain in fairly good condition, much of the life of the original scene is gone and many aids to its interpretation are lost.

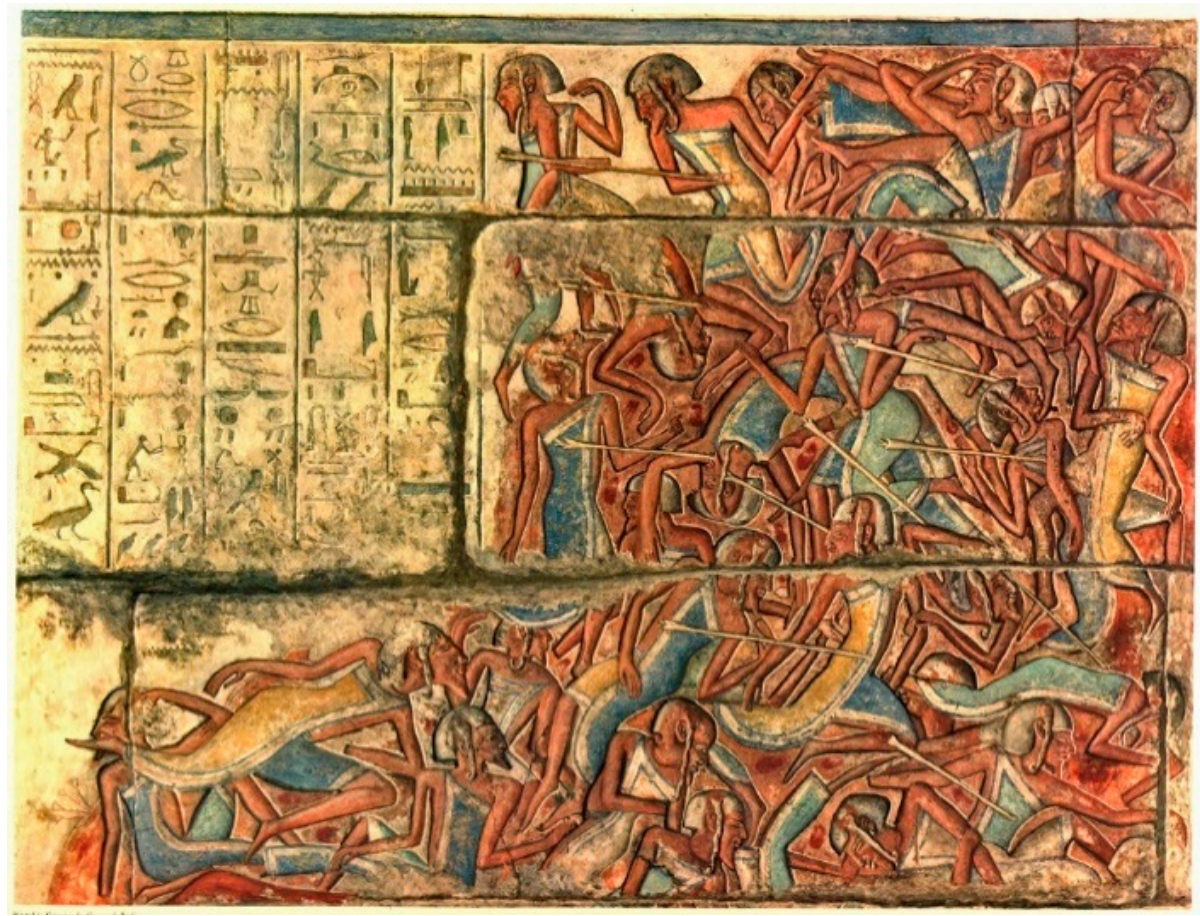

Figure 36. Libyan battle scene in which the paint survived at Medinet Habu. Ramses III. From the (Epigraphic Survey 1930, pl. 20). Courtesy of the Oriental Institute of the University of Chicago.

The naval battle, while being fought between ships, did not take place on the open sea, but rather on a branch of the Nile (Figure 14) (Wachsmann 2013, p. 33 no. 7; Hoffmeier 2018). Archers, led by a colossal Ramses III, appear on the far right of the scene shooting from land, while one soldier pulls a 
Sea Peoples prisoner of war out of the water (Figures 14 and 16). The Sea Peoples' ships appear to be immobile in the water, with their brailed sails furled and no evidence of rowers. Ramses appears to have surprised his foes at anchor (Breasted 1988, IV, §77; Nelson 1943, p. 46; Casson 1995, p. 38; Wachsmann 1998, pp. 166, 168).

The nine ships, four Egyptian (E) and five belonging to the Sea Peoples (N), form three columns with a single ship type representing each side (Figure 16). This is an obvious oversimplification, as the accompanying text describes three vessel types that participated on the Egyptian side alone (Breasted 1988, IV, §65; Edgerton and Wilson 1936, p. 54 no. 20b; Nelson 1943, p. 44). In other words, the 'fleets' taking part in the battle each derive from a single representative prototype vessel repeatedly copied, albeit in varying degrees of detail.

The invading Sea Peoples' vessel, replicated here five times, had been clearly adopted and perhaps adapted from the typical Helladic galley type for which a large corpus of roughly contemporaneous images exists (Figures 10, 21-23) (Wachsmann 1981; 1998, pp. 123-204; 2013, pp. 59-84). ${ }^{21}$ Without doubt, the Sea People's vessel repeatedly portrayed in the Medinet Habu relief must have been based initially on first-hand observation. Artists clearly took part in both Egyptian trading and military expeditions beyond Egypt's borders, as witnessed in Hatshepsut's Punt scenes, Thutmose III's 'Botanical Garden' in the Akhmenu at Karnak, and a relief of Ramses II in Luxor Temple (Figures 12, 13, 37a and 38) (Naville 1898, pls. LXIX, LXXII-LXXV; Davies 1930, p. 30 figure 1; Danelius and Steinitz 1967; Bianchi 1997; Wachsmann 1998, pp. 17 figure 2.11, 18 figures 2.12-13, 19 figure 2.14, 20 figures $2.15-16,21$ figures $2.17-18,22 ; 2013$, pp. 39-40). ${ }^{22}$

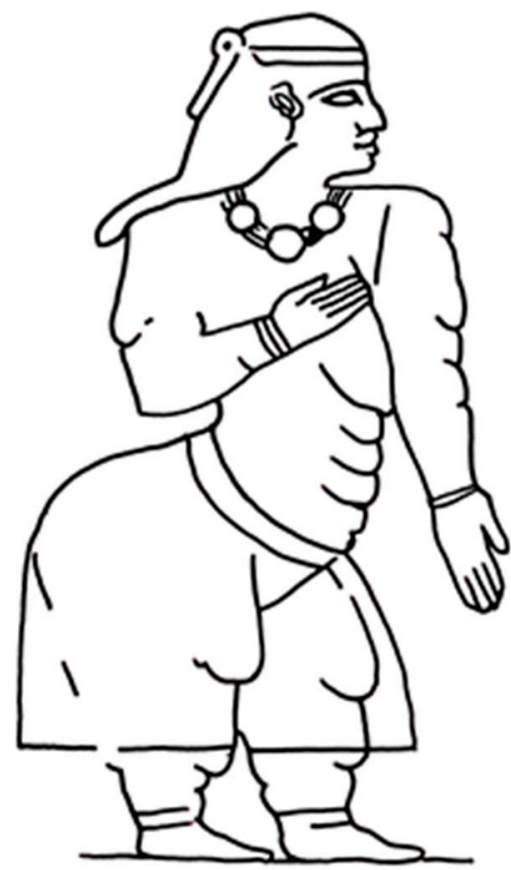

(a)

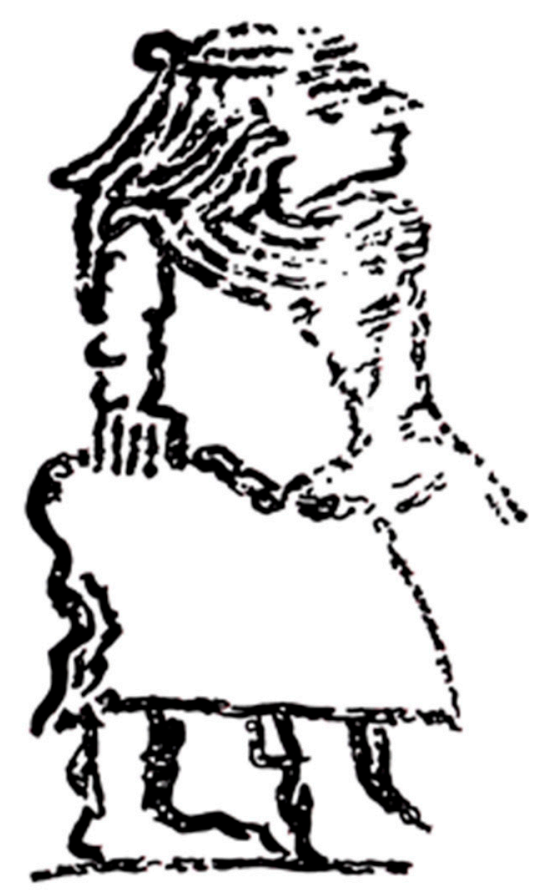

(b)

Figure 37. The queen of Punt as she appears in Hatshepsut's tableau (a) and in an ancient sketch (b). After (Davies 1930, p. 30 figure 1). Drawing: Shelley Wachsmann.

21 For additional examples of this ship type, see below and Section 10. Size Does Matter.

22 On Thutmose III's Botanical Garden at Karnak, see also below, Section 11. To Be or Not to Be. 


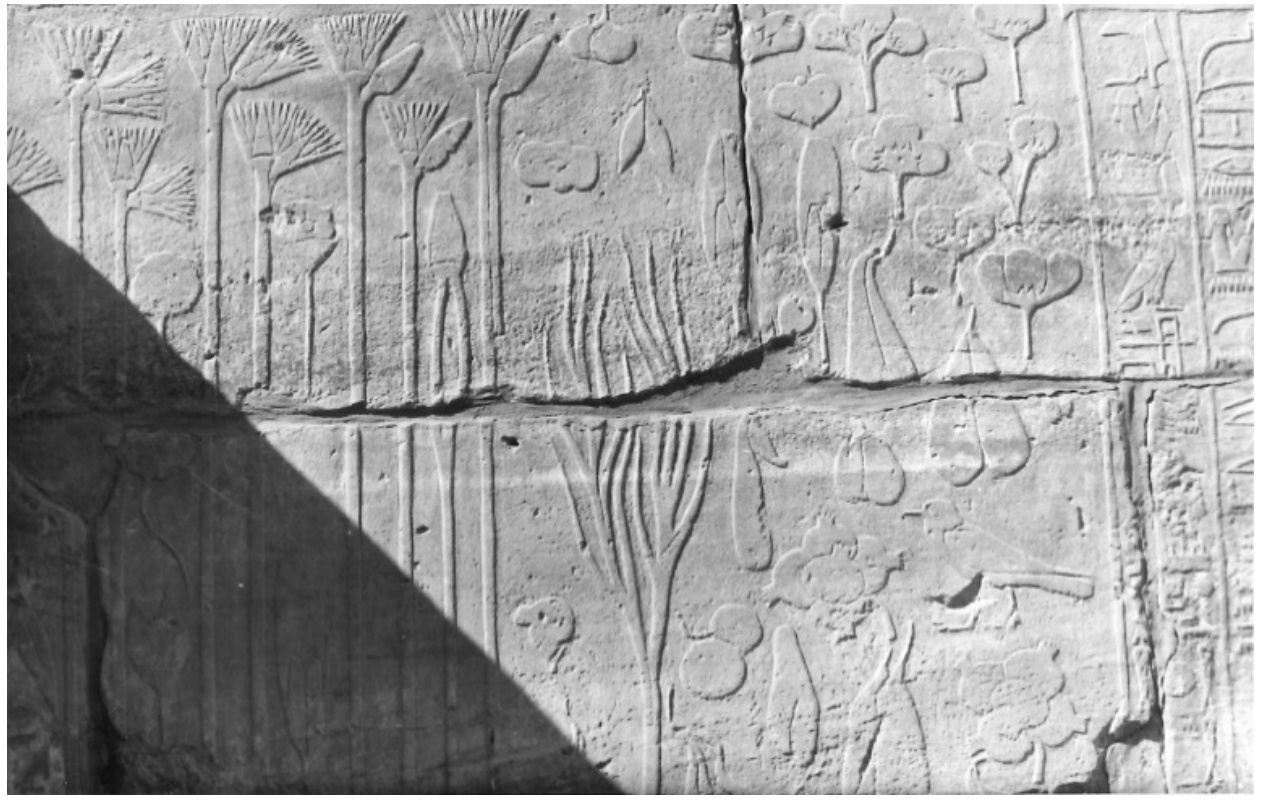

Figure 38. A scene from Thutmose III's Botanical Garden at Karnak Temple. Photo: S. Wachsmann.

In truth, we cannot determine what led to the selection of the specific galley that served as a source for the five Sea Peoples' ships. It could have been chosen because it was the predominant vessel type, because it was unique, or perhaps simply because it was available. Conceivably, the artist chose this ship because it was the one that had been capsized, and yet we have no way of knowing whether this action represents a unique event or a standard Egyptian method of operation during this battle.

The Sea Peoples' capsized vessel (Figure 16 [Ship N.3], Figures 18 and 39b) is the most detailed, displaying three horizontal sections, as opposed to only two on each of the other Sea Peoples' vessels (Figure 16 [Ships N.1-2, 4-5], Figures 17 and 39a). The Egyptian artist(s) provide three clues to the meaning of the additional section, between lines 2 and $X$ in Figure $39 \mathrm{~b}$ in the form of dead and dying warriors.

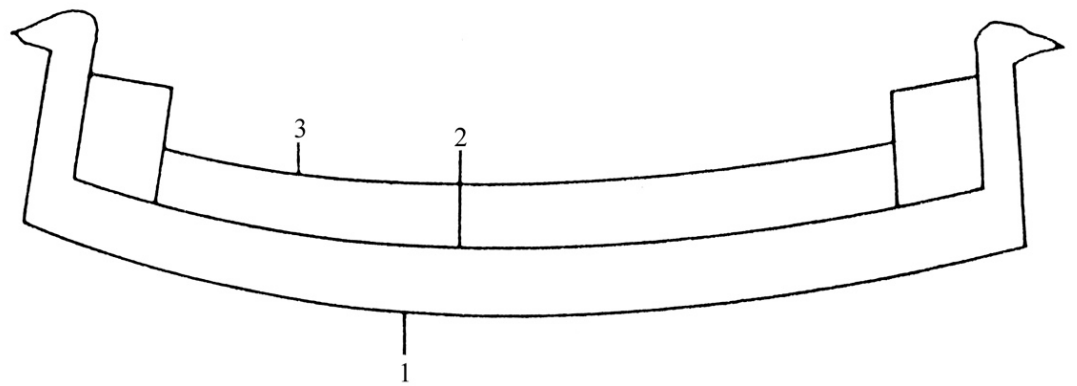

(a)

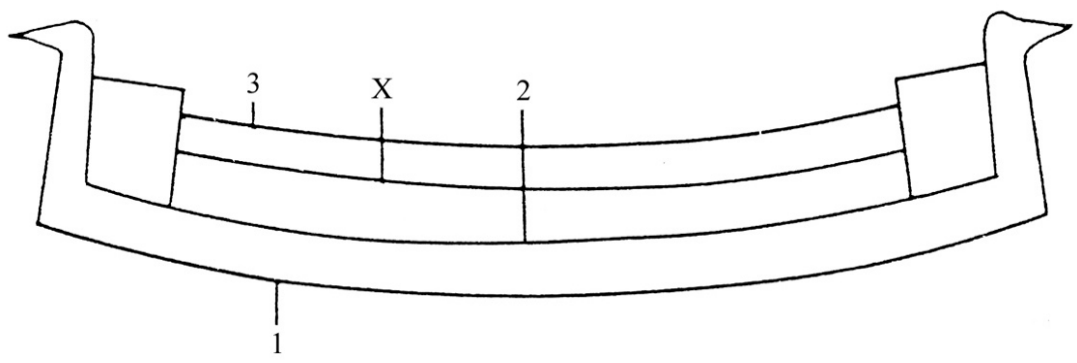

(b)

Figure 39. (a) The horizontal lines on ships N.1-2, 4 and 5 in the Medinet Habu nautical battle scene. (b) The horizontal lines on capsized ship N.3. From (Wachsmann 1998, pp. 170 figure 8.13, 171 figure 8.15). 
In Figure 18 one fellow lies on the upturned hull with his right foot stretched out behind him. His left leg disappears behind the hull, but then reappears in the central panel. Below him, a second figure seems to be falling out of the ship: his legs straddle the screen (Figure 39b, panel 3-X), his left leg disappearing behind it and then reappearing in the central panel. To the left of this figure, a third warrior is wrapped around the screen, with his body reappearing in the central panel once again.

All three figures indicate that the central panel must represent an open space, or rowers' gallery, through which oars could be plied (Figure 39b, 2-X). Additionally, it is possible to determine that these vessels also had raised decks in their fore and stern castles and that a center-line deck ran the length, although not the breadth, of the ship by studying the positioning of warriors in the other ships in relation to the hull and decking (Figures 17 and 40). ${ }^{23}$ Since I first published this reconstruction for the Medinet Habu Sea Peoples' ships in 1981, it has been confirmed by discoveries from Pyrgos Livanaton (Homeric Kynos) in Greece, from Bademgediği in Turkey, as well as from a restudy of the Gurob ship-cart model (Figures 10 and 41) (Wachsmann 1981; 1982; 1998, pp. 131 figure 7.8, 132 figure 7.9; 2013, pp. 13 figure 1.13, 14 table 2, 15, 16 table 3 and figure 1.16, 63 figure 2.34, 67 figure 2.39: E, 74-75, 76 figure 2.47; Dakoronia 1990; 1995; 2006; Mountjoy 2005; 2006; 2011).

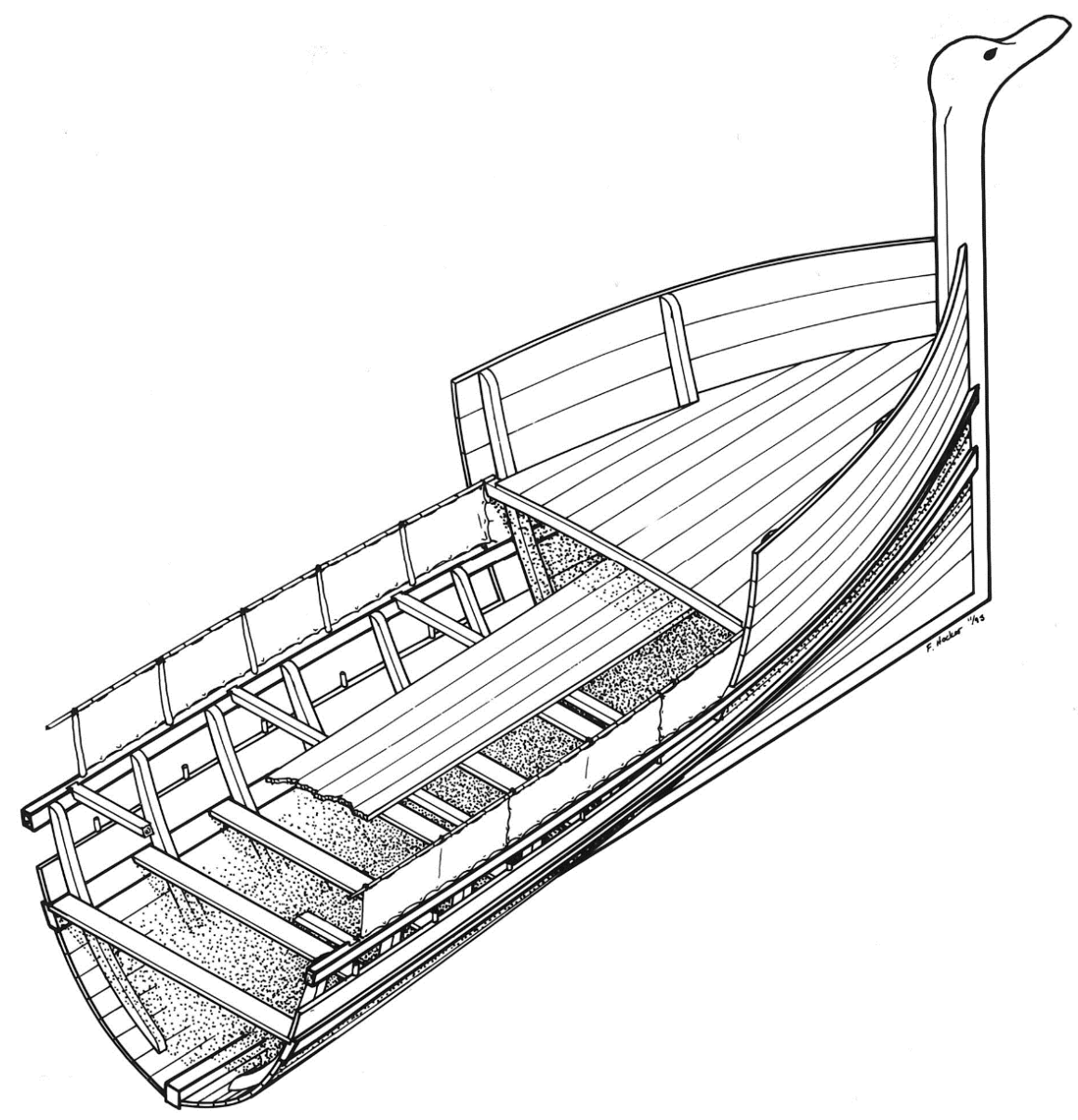

Figure 40. A study of how warriors interact with their ships in the Medinet Habu naval battle scene enables a reconstruction of the basic details of the ship. Drawing: Fred Hocker. From (Wachsmann 1998, p. 173 figure 8.18: A).

23 Lionel Casson (1995, p. 51, figures 67-69) had previously used the same method to interpret the construction of Geometric-period galleys. 


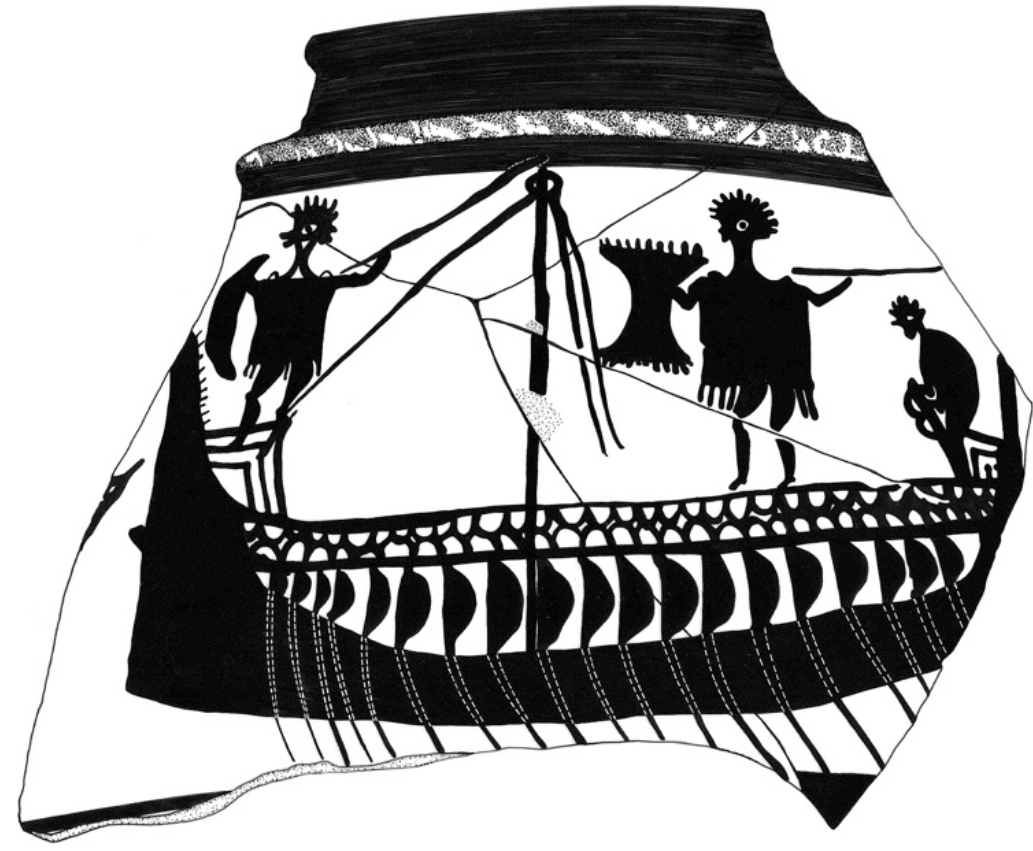

(a)

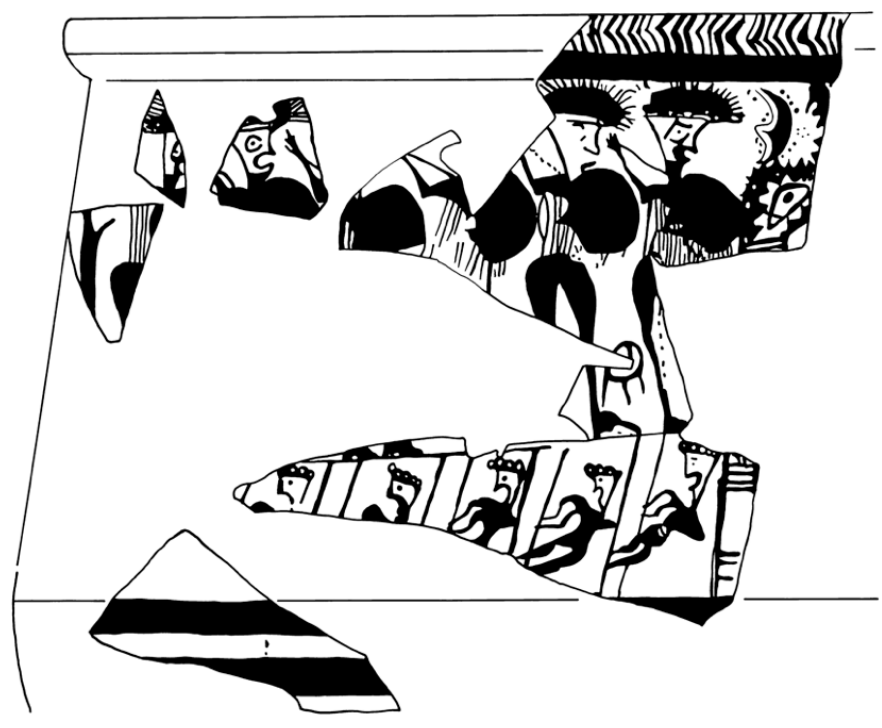

(b)

Figure 41. Representations of Helladic-style galleys with rowers visible in the open rowers' gallery. (a) A ship depiction from Pyrgos Livonaton, Homeric Kynos, in Greece only displays the torsos of the rowers at their oars, with their heads hidden behind the screen. Late Helladic IIIC. (b) Ship depiction from Bademgediği, Turkey. The artist has expanded the rowers' gallery to reveal the rowers working their oars. In both scenes, figures standing above them indicate a deck running the length of the hull. Compare figures 17-18. Transitional Late Helladic IIIB-C Early or Late Helladic IIIC Early. NTS. From (Wachsmann 2013, p. 67 figure 2.39: E, 77 figure 2.47: B) (b) after (Mountjoy 2005, pl. XCVI). On the dating of (b) see (Mountjoy 2011, pp. 484, 486 figure 3: bottom).

One element missing in the Medinet Habu representations, and particularly on the capsized ship, are the stanchions, vertical posts that would have been essential in the prototype vessel to support the superstructure. Stanchions regularly appear on depictions of this ship type, being represented as a 
'horizontal ladder pattern' (see, for example, Figures 10, 21b and 41b, [Figure 35: middle for a row of stanchions on a Geometric-period galley]). ${ }^{24}$ It is possible that the stanchions originally existed solely in paint and have long since disappeared (Wachsmann 1998, p. 172). Alternately, and more likely in my view, the artists never included the stanchions in an attempt to simplify the ship's appearance. Lionel Casson (1995, p. 71 no. 6) suggests a similar explanation for the intermittent appearance of stanchions on the Geometric-period descendants of these vessels: here, the artists included the stanchions when oarsmen were absent, but omitted them when the rowers are seen pulling at their oars. The two Late Helladic IIIB-C ships in Figure 21 appear to follow the same methodology, as they can both be interpreted as depicting galleys with open rowers galleries, one (a) by displaying the rowers antithetically arranged below figures standing on the deck (Wachsmann 1998, pp. 141 figure $7.28,142-143)$, the other (b) with the typical horizontal ladder pattern representing an open rowers' gallery intersected by stanchions, but without oarsmen. However, this rule is not evenly applied in the Late Helladic IIIB-C. Note that the Bademgediği ship representation depicts both oarsmen and stanchions together (Figure 41b). As noted, inconsistency in detail of representation in this particular corpus is to be expected. ${ }^{25}$

\section{Size Does Matter}

Ancient representations were not intended as scale drawings or models. In some representations of vessels, the relative scale of different elements can be disproportionally displayed or overemphasized, while other details go missing. During the Bronze Age (circa 3000-1070/1050 BC), for example, when the boom-footed rig was in use, artists emphasized the multiple lifts supporting the yard and boom in their imagery while almost invariably ignoring other elements of the rig (Figures 5, 9, 12, 25 and 29a). ${ }^{26}$ At times, this focus on specific ship's elements resulted in the artists skewing them to a scale larger than the other parts of the ship, as the two following instances demonstrate.

For Aegean galleys, the open rowers' gallery appears to have most impressed those who created this imagery (Figures 10, 18, 21 and 41). ${ }^{27}$ Indeed, in some cases, this feature so overwhelms the vessel that it becomes a shorthand manner of representing the ship itself, with oars and rigging being occasionally added (Figures $21 \mathrm{~b}, 41 \mathrm{~b}$ and 42 ).

Similarly, but of a much later date, a graffito of a Roman galley from Khirbet Rafi, Israel, dating to the time of the Bar Kokhba Revolt (AD 132-135) magnifies details related to the stem and stern-the forecastle, the artemon sail, the volute, the ship's (triton?) guardian deity (tutela), and the stern with its hanging lamp—while shrinking the hull (Figure 43) (Kloner and Wachsmann 1978; Hornell 1943). Of course, human figures regularly appear in varying, often incorrect, scales in relation to the ships that they inhabit, being sometimes represented to more than one scale on the selfsame ship representation (Figures 4, 5, 9, 17, 18, 21a, 34a,c, 35b and 44).

\footnotetext{
24 See also below, Section 10. Size Does Matter.

25 See above, Section 6. On Ship Typologies.

26 Dates for the Bronze Age in the eastern Mediterranean vary by region. Here I employ the accepted Aegean chronology (Manning 2010, p. 23 table 2: 2). Sometimes we must concede that certain questions will remain unresolvable with the evidence at hand. For example, in Figure 42a did the artist invert the galley in the larnax in order to signify that the bones interred in it were the result of a shipwreck, because the artist painted when bending over the larnax or for some other unknown reason?

27 On the three-dimensional evidence for stanchions on the Gurob ship-cart model, see (Wachsmann 2013, pp. 13-16).
} 

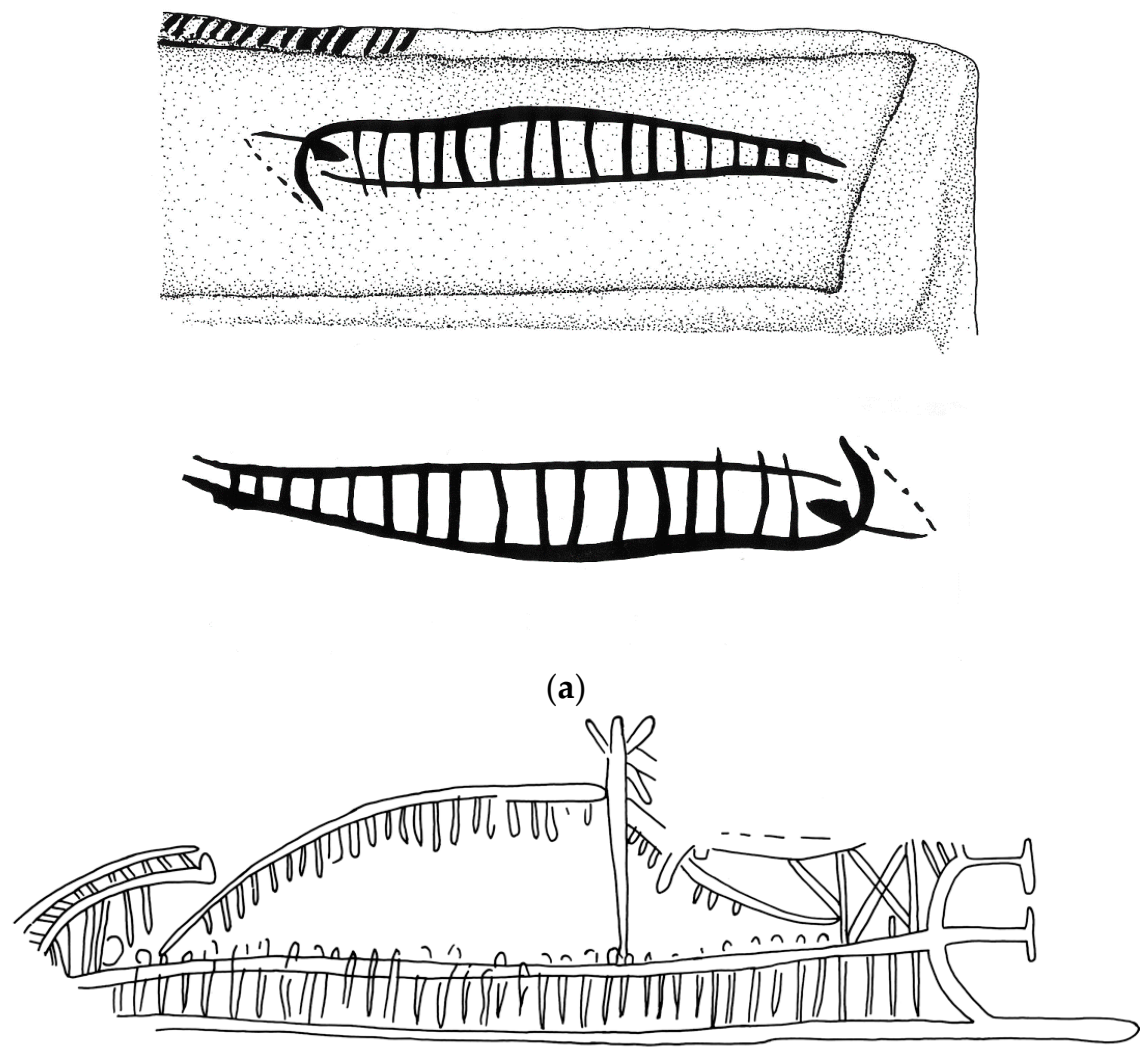

(b)

Figure 42. In some cases, rough representations of galleys with open rowers' galleries 'become' the gallery, sometimes with rigging and oars added (NTS). (a) Ship graffito depicted inverted on the interior of a Late Minoan larnax. Below, the ship reversed. (b) Late Geometric-period galley from Khaniale Tekke, near Knossos, Crete. From (Wachsmann 1998, pp. 131 figure 7.7, 138 figure 7.20) after (Gray 1974, G47, Abb. 11; Boardman 1967, p. 73 figure 6: 21).

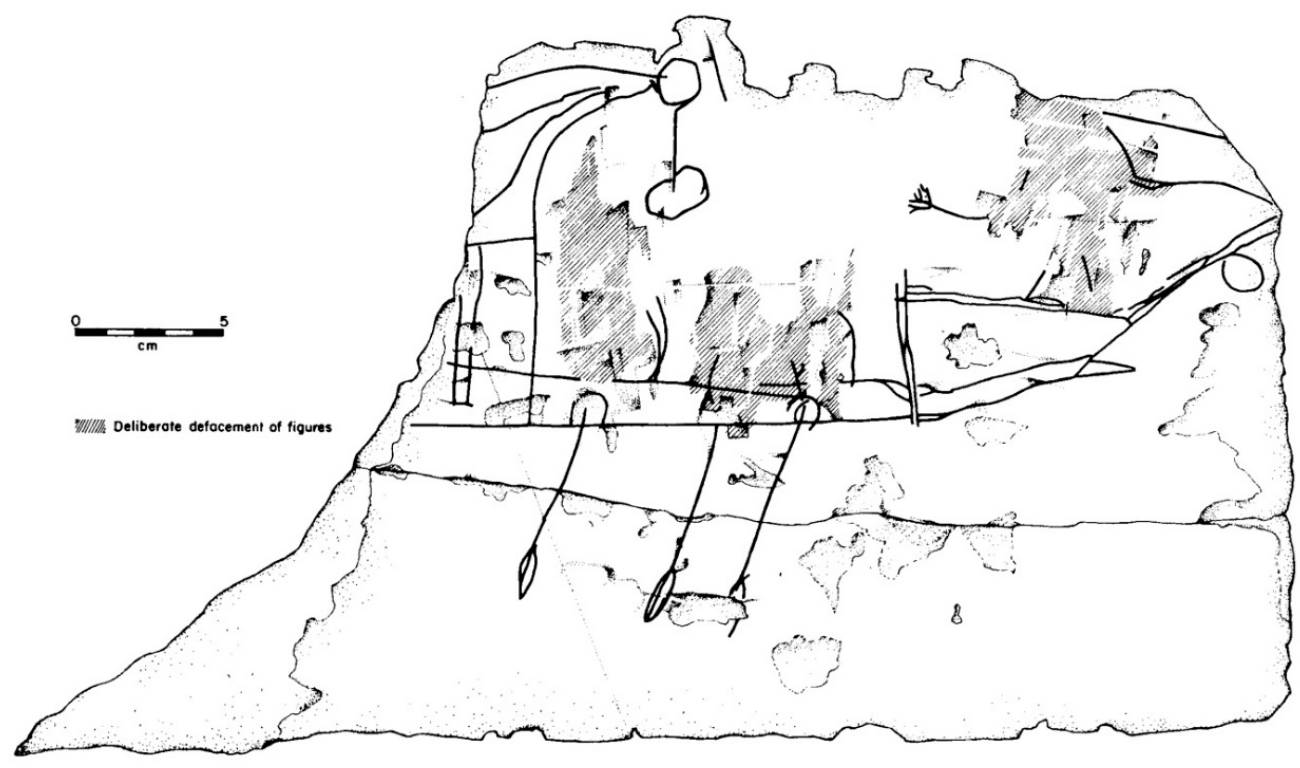

Figure 43. The Khirbet Rafi ship graffito, Israel. First half of second century AD. From (Kloner and Wachsmann 1978, p. 230 figure 3). Used by permission. 


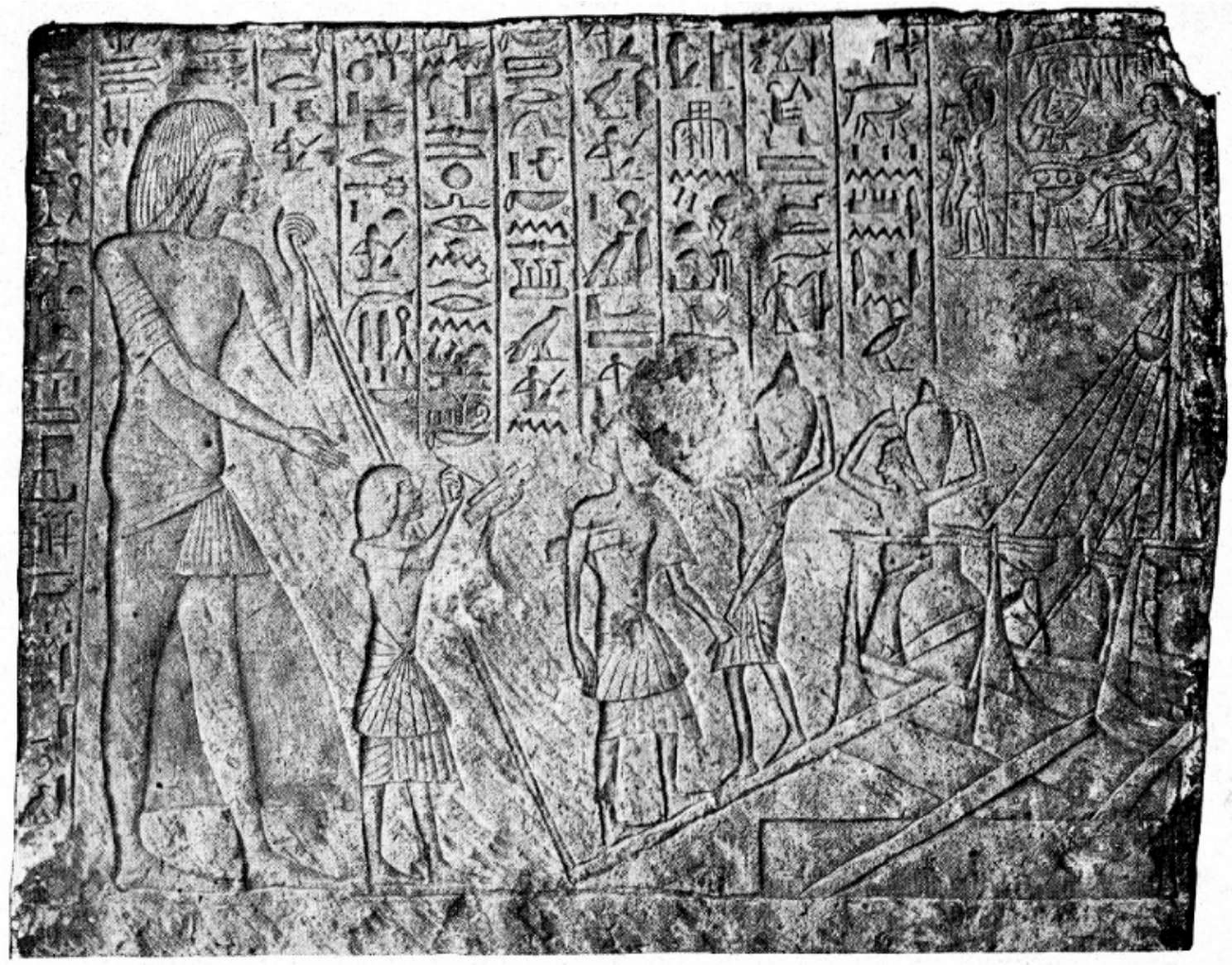

Figure 44. Nautical relief from the tomb of Iniwia. Late XVIIIth or early XIXth Dynasty. From (Von Bissing 1913, Taf. 10 no. 21).

When dealing with ship models, similar problems of relative proportions arise. The most common of these seems to be a distortion of the prototype vessel's length-to-beam ratio. For example, compare a wooden model of a Nile travelling ship from Tutankhamun's tomb, which probably correctly replicates the prototype vessel's relative beam-to-length proportions (while at the same time distorting its sheer plan, in typical Egyptian style) with the stubby terracotta ship model from Byblos discussed above (Figure 19).

Details of a model's construction can also result in deviations from the prototype vessel. On the Gurob ship-cart model, the vertical post at the stem should follow the line of the bow, as it appears consistently on representations of the Helladic galley with open rowers' gallery (Figures 17, 18, 21, 22 and 41). Nevertheless, the model maker intentionally inserted the stem, incorrectly, aft of the line of the bow, placing it at the center of the forecastle, presumably in order to secure the forecastle deck in place (Figures 10 and 45) (Wachsmann 1998, p. 156; 2013, pp. 8, 11 figure 1.11).

Ship models may also serve specific functions that can result in significant deviations from their prototype ships. A bronze ship model from the Athenian Acropolis illustrates this issue.

The Athenian Panathenaia celebrated the traditional birthday of the city's patron goddess, Athena. On the last day of the festival, she received a singular garment (peplos) that was brought to her in an impressive procession, parts of which are the subject of the Parthenon frieze (Wachsmann 2012, pp. 237-38). For at least a millennium, iterations of the Panathenaic ship, a large vessel transported on wheels that never saw water beneath her hull, brought the peplos to the Acropolis.

The fourth-century Erechtheion ship model might be the most detailed representation known of a Panathenaic ship (Figure 46) (Wachsmann 2012, pp. 248-55; 2013, pp. 135-46). Nevertheless, this ex

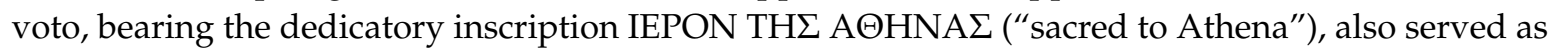


an oil lamp. The lamp nestles between the ram and the forecastle and causes a distortion in the model's bow. This becomes clear when the model is compared to the most securely identified, although badly damaged, representation of the Panathenaic ship, which appears on the Calendar Frieze, which is imbedded in the Church of Ayios Eleutherios, or Little Metropolis, in central Athens (Figure 47a,c) (Wachsmann 2012, pp. 247 figure 11, 252 figure 16).

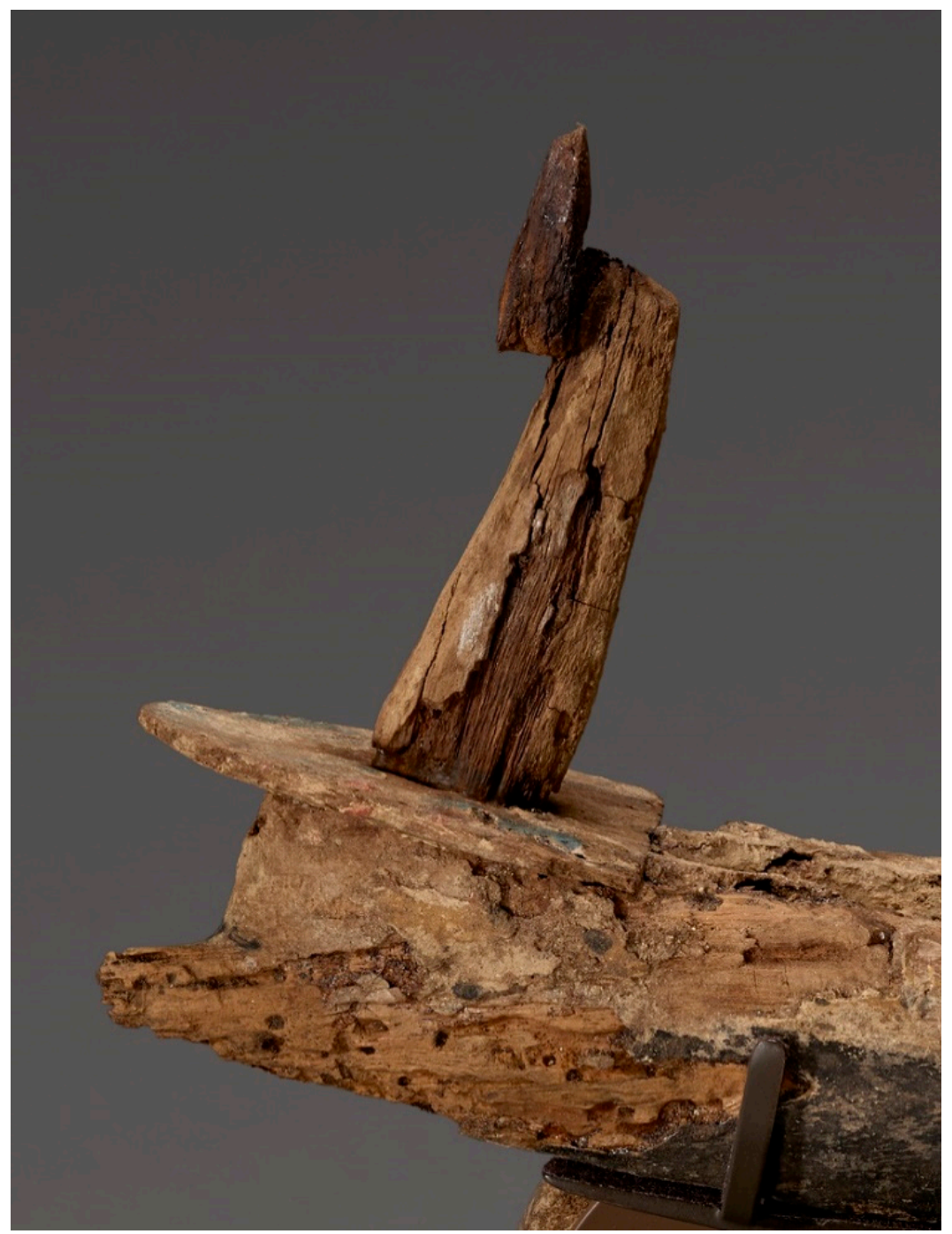

Figure 45. Detail of the Gurob ship-cart model's bow. Note that the stem rises from the center of the forecastle deck, locking it in place. This positioning results from a modeling issue and does not reflect the reality of the prototype ship on which the stem would have risen from the bow. Courtesy of the Petrie Museum of Egyptian Archaeology, University College, London. 


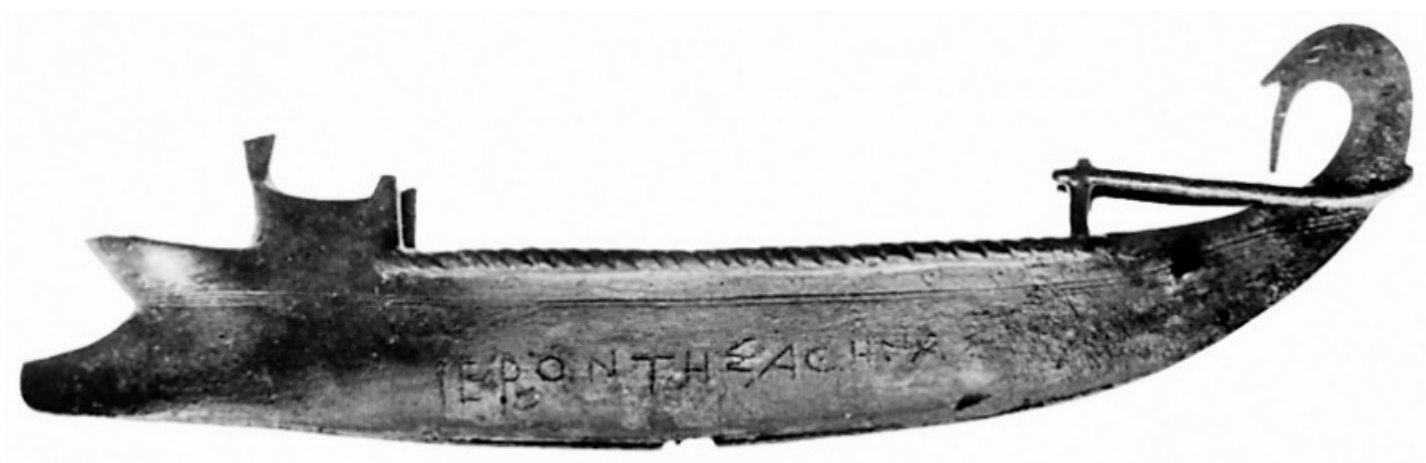

(a)

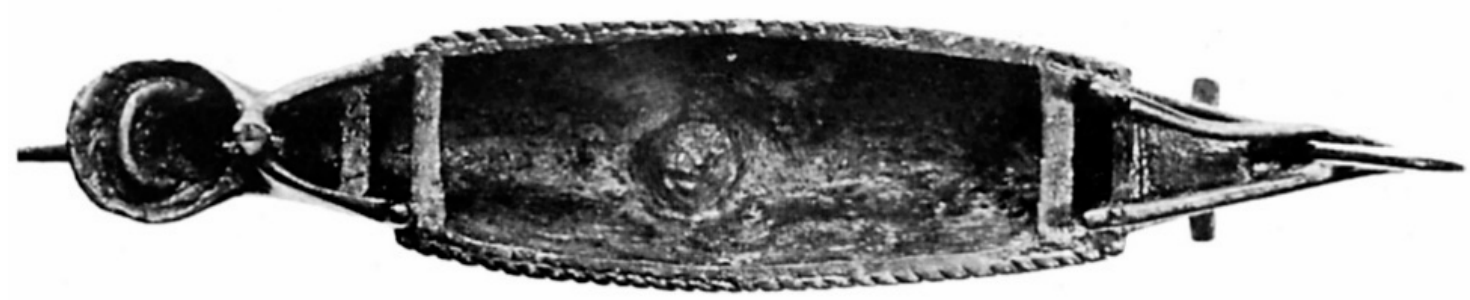

(b)

Figure 46. The Erechtheion model, (a) starboard sheer view, (b) top view. Note the cup-shaped lamp between the bow and the forecastle. From (Basch 1987, p. 229 figure 477). Courtesy Hellenic Institute for the Preservation of Nautical Heritage.

Additionally, early representations of the Erechtheion model show it with a stump amidships, which, when the model was discovered, survived to approximately the height of the gunwale (Wachsmann 2012, pp. 254 figure 17, 255; 2013, pp. 145, 149 figure 3.66). Currently, only a slight mark survives (Figure 46b) (p. 249 figure 13: A). Morrison and Williams (1968, p. 179 Clas. 20) identify this element as a mast tabernacle (histopode). However, this does not comport with the Calendar Frieze ship. A careful study of its surviving remnants indicates that the ship carried a raking mast stepped well aft of midships (Figure 47b) (Wachsmann 2012, pp. 244, 245 figures 6-7, 246). This leads me to suspect that the stump, rather than indicating a mast, represents the remnants of a stalk that served to suspend the model at its center of gravity (p. 255 no. 71). 


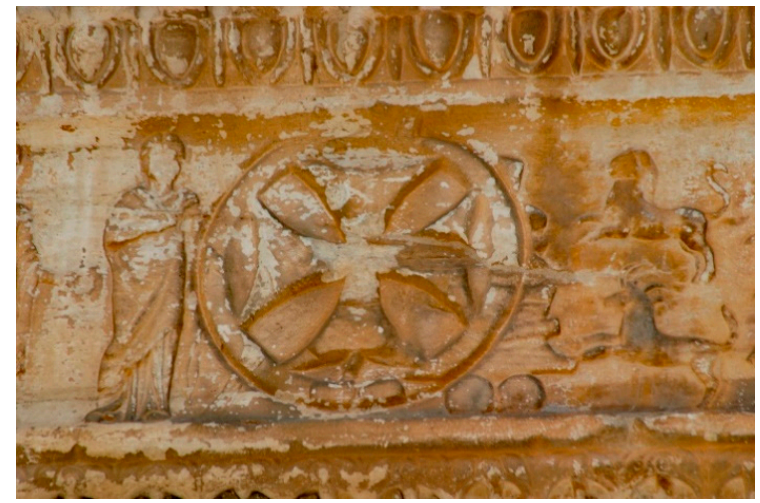

(a)

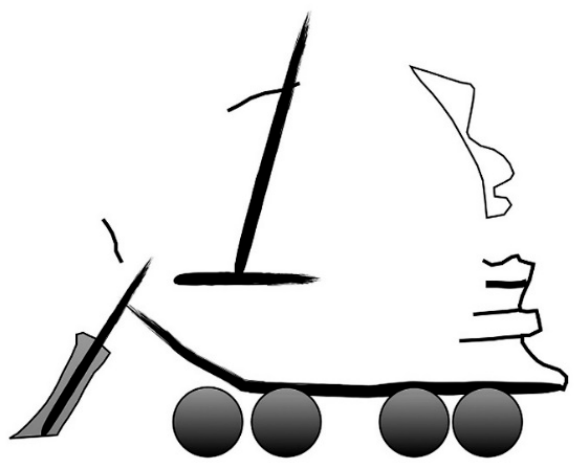

(b)

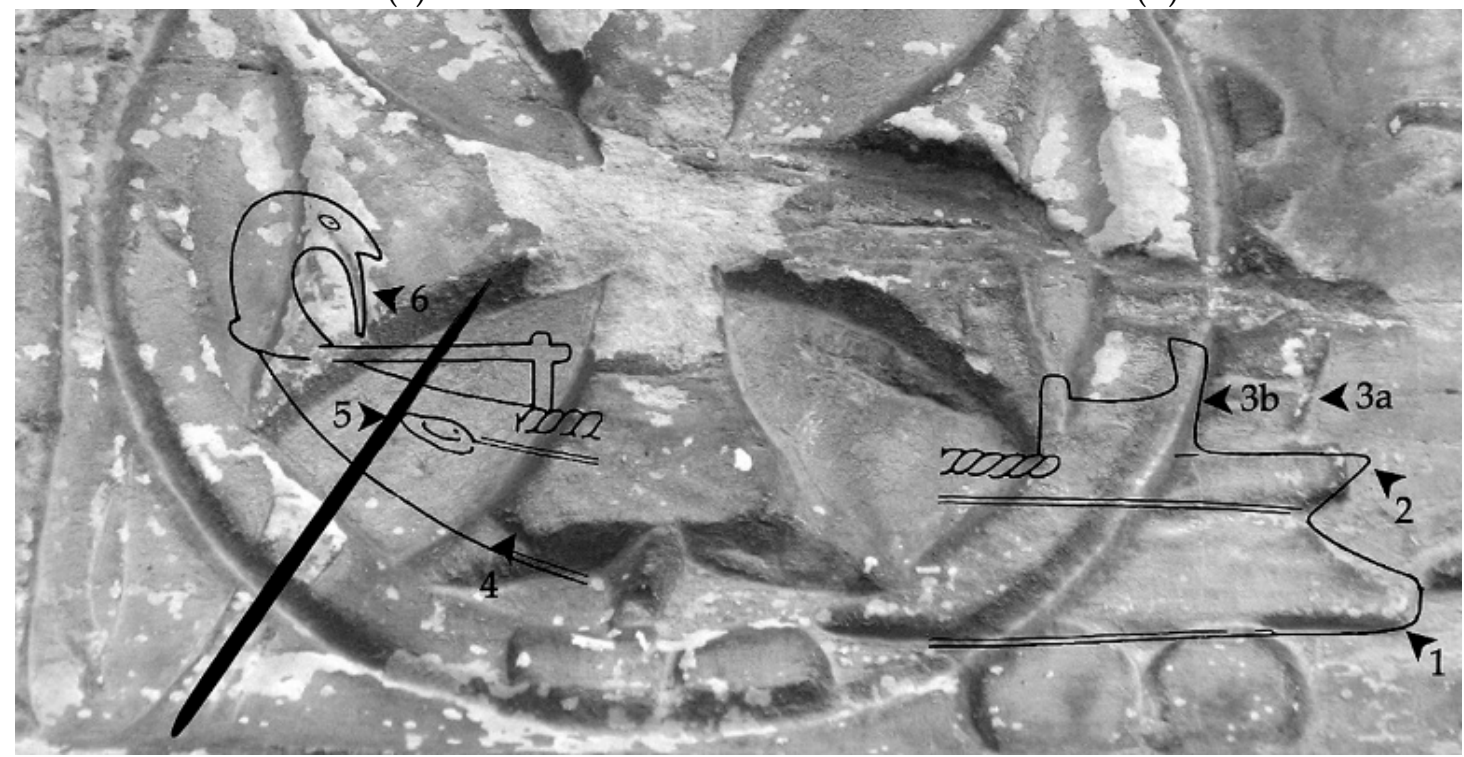

(c)

Figure 47. (a) The Calendar Frieze Panathenaic ship. Small Metroplitan Church (Church of St. Eleutherios) in Central Athens. Dates for the frieze vary from the Late Hellenistic period to the second-century AD. A Byzantine-period cross has largely obliterated the ship. (b) A careful study of surviving details allows for a reconstruction of the Calendar Frieze Panathenaic ship. (c) When an outline of the Erechtheion model is placed over the Calendar Frieze Panathenaic ship, the results are strikingly similar, despite the disparate materials used in the representations. Note that the model's oil lamp (2), placed above the model's chisel-shaped ram (1) resulted in its forecastle (3b) being moved aft relative to the forecastle on the frieze (3a). The frieze's artists were limited in horizontal space so they omitted much of the run of the hull. When this is taken into account the through-beam on the model matches the location of the quarter rudder on the frieze (5). Similarly the beak of the bird head stern decorations on both the frieze (fragmentary) and the model (6) coincide. This similarity is particularly remarkable given that the two representations are probably based on different iterations of the Panathenaic ship. (a) photo by Shelley Wachsmann; (b,c) from (Wachsmann 2013, pp. 143 figure 3.60: B, 148 figure 3.65: B).

\section{To Be or Not to Be}

I own a delightfully whimsical image of a submarine that I purchased on the Aegean island of Kythera from an artist who specializes in Greek Orthodox icons (Figure 48). It constantly reminds me that some ship depictions represent vessels that never actually existed. Today, of course, one can point to innumerable examples of this phenomenon, from Captain Nemo's Nautilus to the Beatles' Yellow Submarine, and other fictional ships, as well as fictional space ships à la the Millennium Falcon of Star 
Wars fame. Anyone studying ancient ship iconography must be aware that imaginary depictions of vessels from antiquity, although admittedly rare, do exist.

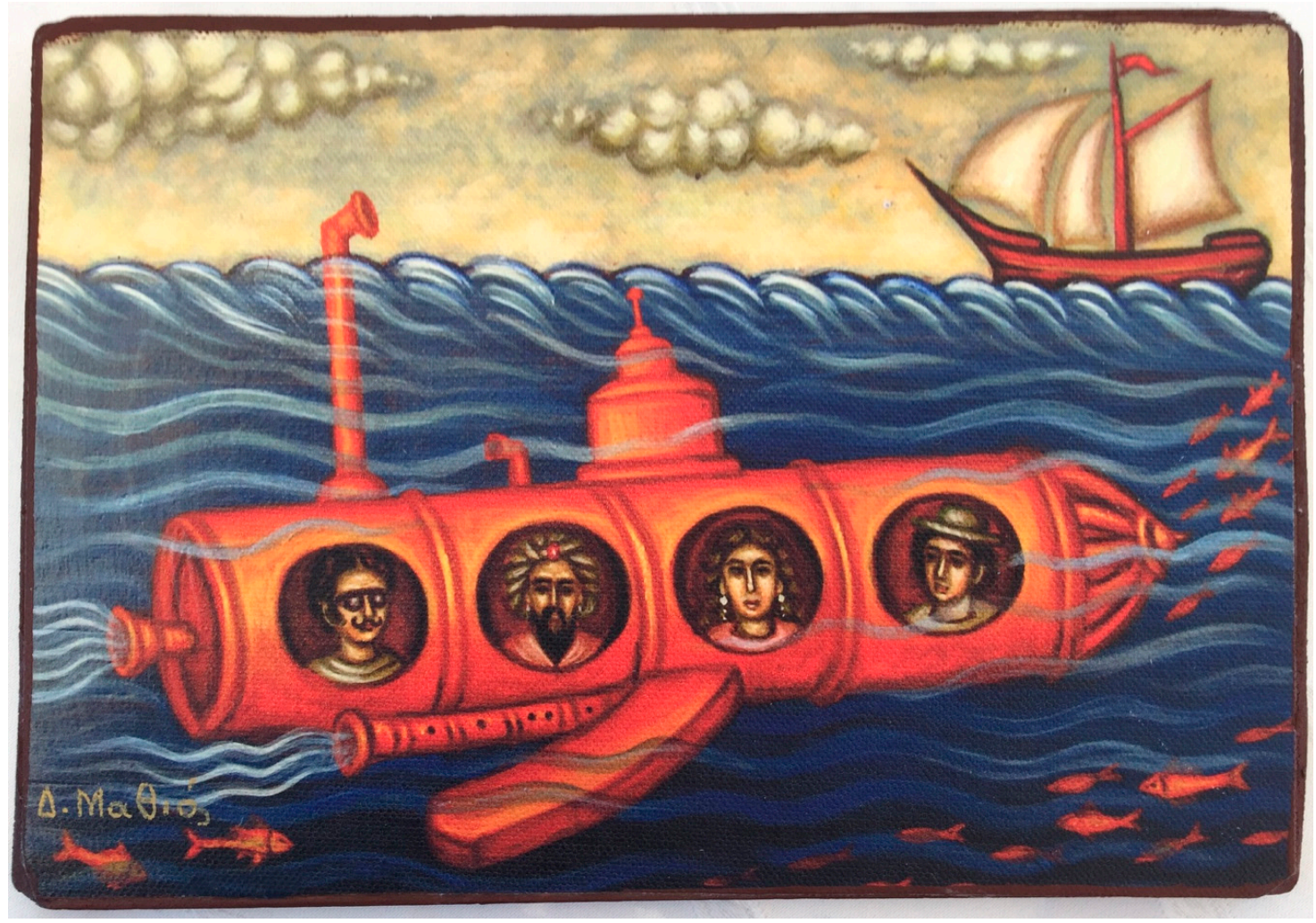

Figure 48. Icon of an imaginary submarine. Painting: D. Mathios.

To be clear, I am not referring to the innumerable ancient depictions of mythological ships, or of biblical passages with nautical themes and the like, which often copy contemporaneous prototypes and can have great value. Here, I specifically refer to ship representations that can only be termed 'illusionary' in the sense that the vessels appear in manners in which they simply could never have existed in reality. The following two examples illustrate this phenomenon.

In Egyptian art, one must consider the influence of 'hybridism' (Wachsmann 1987, pp. 4-9; 1998, pp. 54-56). Artists created non-existent objects, human figures, and even entire scenes by combining elements from two or more sources. Davies (1930, p. 36 figure 6, 37 figure 7) notes that details from gold vessels taken as booty from Syro-Canaanite polities in the XIXth Dynasty become unified in a single depiction, while scenes of Libyan plunder from the campaigns of both Seti I and Ramses II depict hybrid creations of these same vases, weaving together various Syro-Canaanite themes.

One of the most fascinating examples of hybridism can be observed in Thutmose III's 'Botanical Garden' (Figure 38). The walls of this chamber contain some 275 representations of plants, birds, and other animals from the Syro-Canaanite littoral (Davies 1930, pp. 34, 35 figure 5; Bodenheimer 1949, pp. 257, 258 figure 32, 259; 1960, pp. 167-68; 1972, p. 46 figure 32; Wreszinski 1988, pls. 26-33; Wachsmann 1987, pp. 5-6, pl. II; Beaux 1990). Although the artists accurately depicted the fauna, this does not always hold true for the flora. While some plants are anatomically correct, others appear based either on imprecise memory or are simply clever inventions.

Hybridism applies to some representations of foreigners in Egyptian art. The tomb of Menkheperrasonb (TT 86; late Thutmose III) contains a remarkable scene of foreign visitors with a display of their wares that were brought as trade or tribute (Davies and de Garis Davies 1933, pp. 3-9, pls. I, IV-V; Wachsmann 1987, pp. 6-9, pls. XXIV-XXIX). In the scene's top register, the first three figures are Syro-Canaanites (Figure 49a,b, Register 1). All of the other figures behind them have typical 
Minoan attributes: clean-shaven, dark red skin, and skirts similar to those worn by Aegean porters in the tomb of Rechmire (TT 100; Thutmose III-Amenhotep II) (Davies 1943, pls. XVIII-XX: top register; Wachsmann 1987, pp. 34-35, pls. XL-XLIII). The second register, however, bears some characters who never existed in reality. While the first three men introducing the register are again Syro-Canaanites, interspersed between their retinue stride hybrid figures created by skillfully amalgamating typical characteristics belonging to both Syro-Canaanites and Minoans (Figure 49a,b, Register 2, Figure 50) (Wachsmann 1987, pp. 6-9, pls. III, XXXIV-XXXVIII).

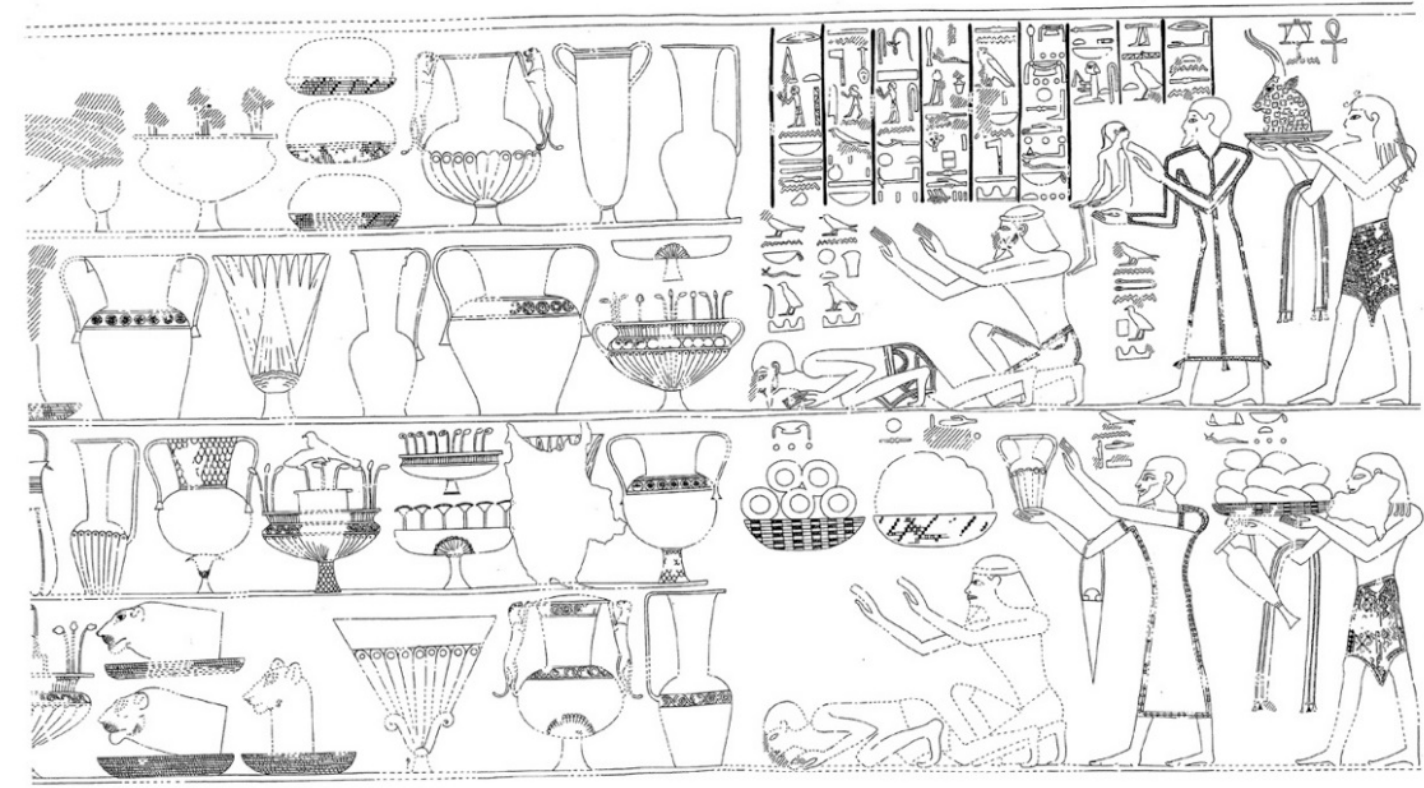

(a)

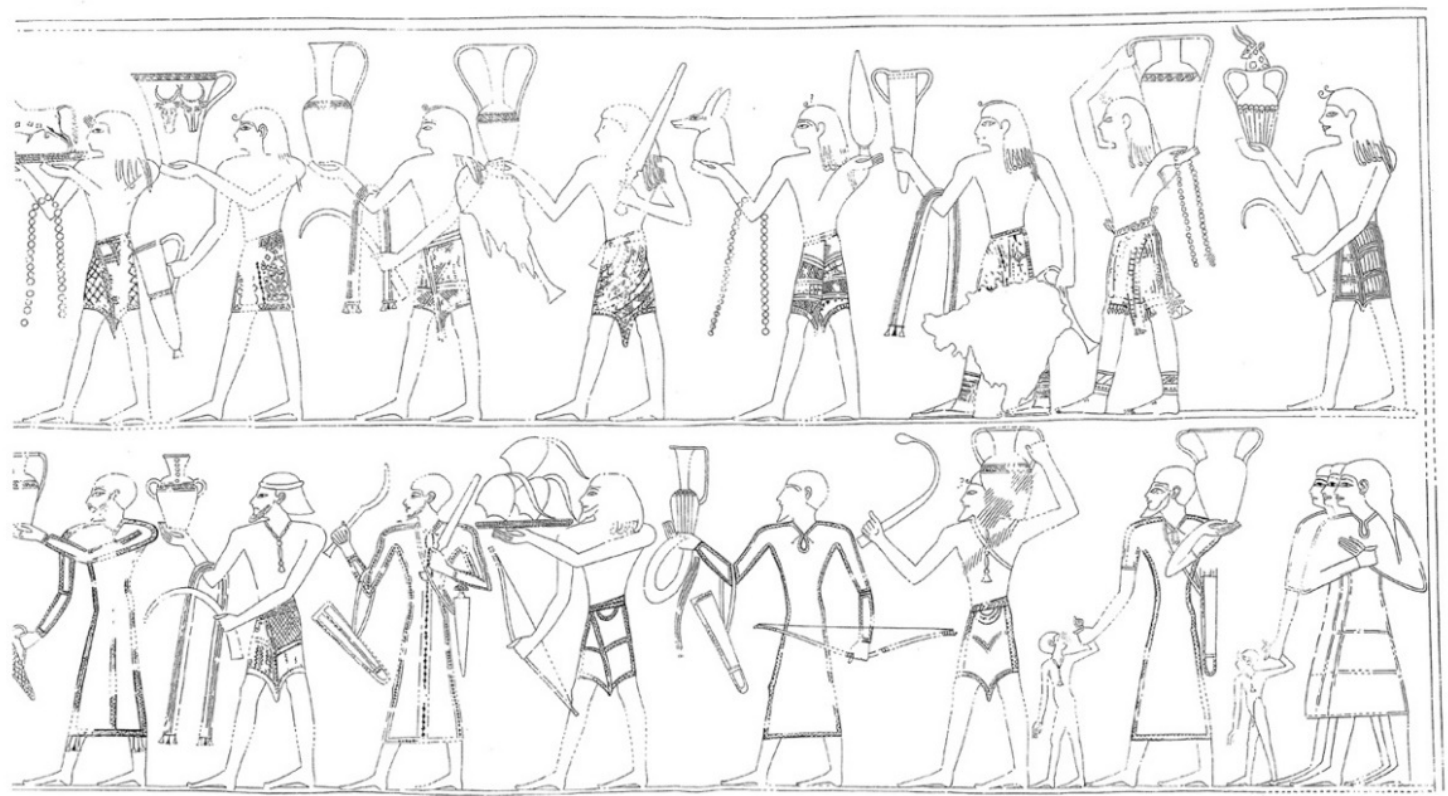

(b)

Figure 49. Registers I-II of foreign tribute from the tomb of Menkheperresonb (TT 86). Thutmose III. From (Davies and de Garis Davies 1933, pls. IV-V). 


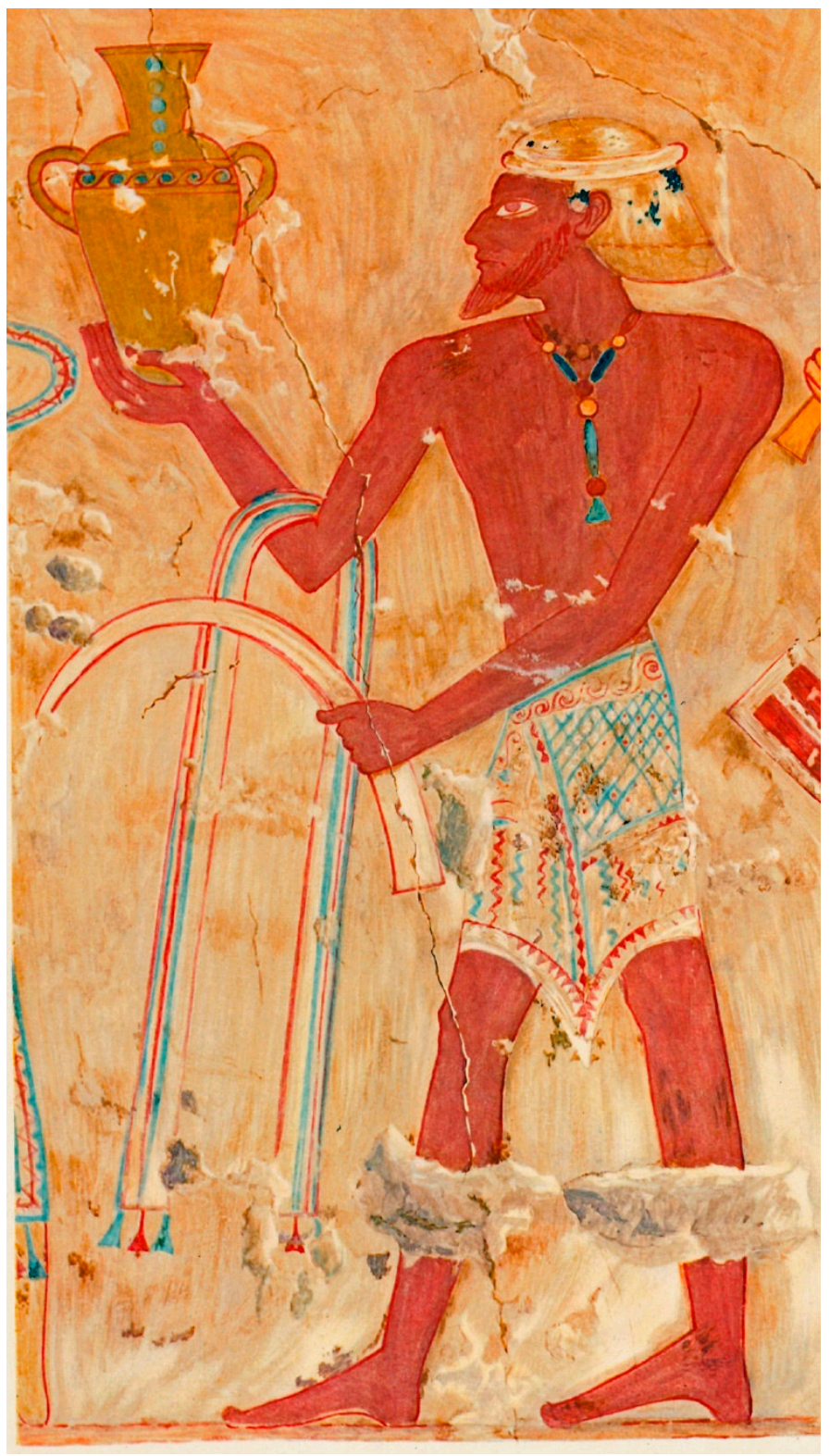

Figure 50. 'Hybrid' representation of a human in the tomb of Menkheperresonb (TT 86). The figure's red skin color and skirt are Minoan while the beard and hair are Syro-Canaanite. Thutmose III. After (Davies and de Garis Davies 1933, pl. I).

A relief from the late XVIIIth or early XIXth Dynasty tomb of Iniwia (Cairo EM 11935), first published by Friedrich Wilhelm Von Bissing (1913, Taf. 10 no. 21) and discussed by Bjorn Landström (1970, pp. 138 Figure 403,139) represents an example of hybridism as it can pertain to a ship representation (Figure 44) (Wachsmann 1998, pp. 54-60). ${ }^{28}$ The relief depicts three ships' bows, which replicate those of Hatshepsut' seagoing Punt ships from her mortuary temple at Deir el Bahri (Figure 12). These Punt scenes had a demonstrable fascination for ancient Egyptians, as evidenced by a later sketch of the morbidly obese queen of Punt (Figure 37b) (Naville 1898, pl. 69; Davies 1930, pp. 30 figure 1, 31; Peck 1978, p. 115 figure 46). Additionally, the leftmost of the vessels carries a hogging truss-a longitudinal support system required by Egyptian seagoing ships, at least up to the time of 
Hatshepsut, when our visual evidence for Egyptian seagoing ships goes dark-to prevent them from coming apart in open water due to their lack of proper keels (Figures 12 and 51a: Arrows). ${ }^{29}$

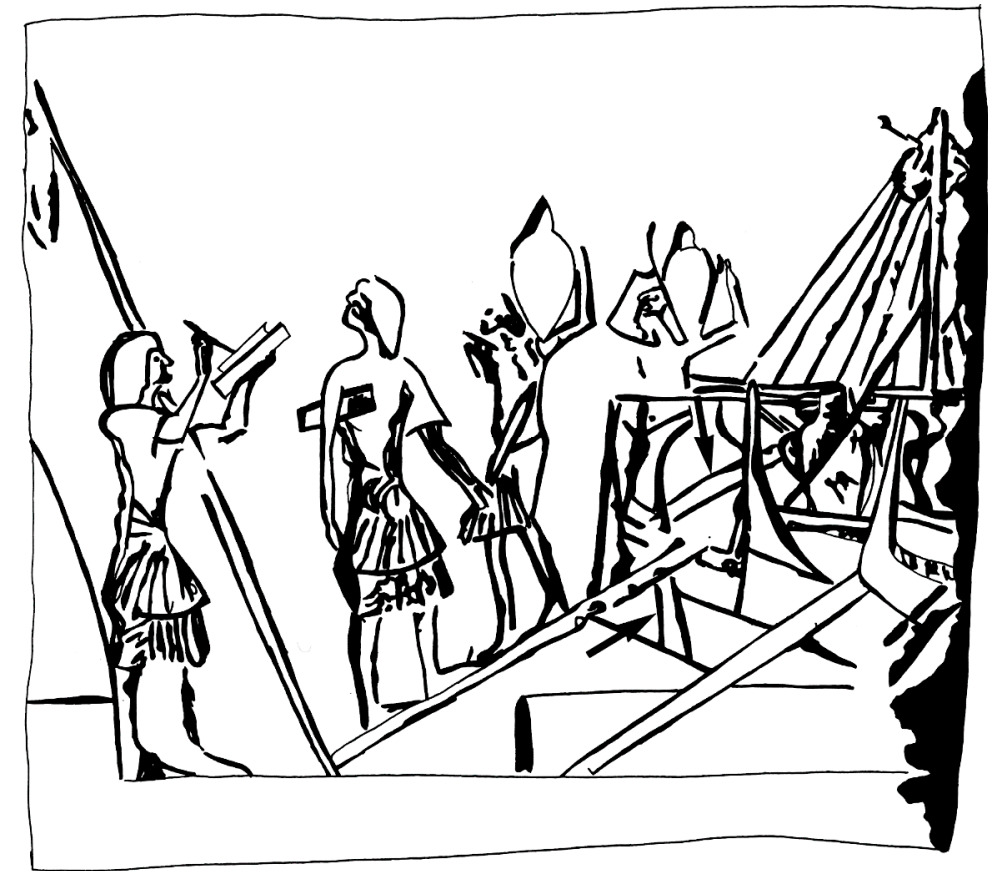

(a)

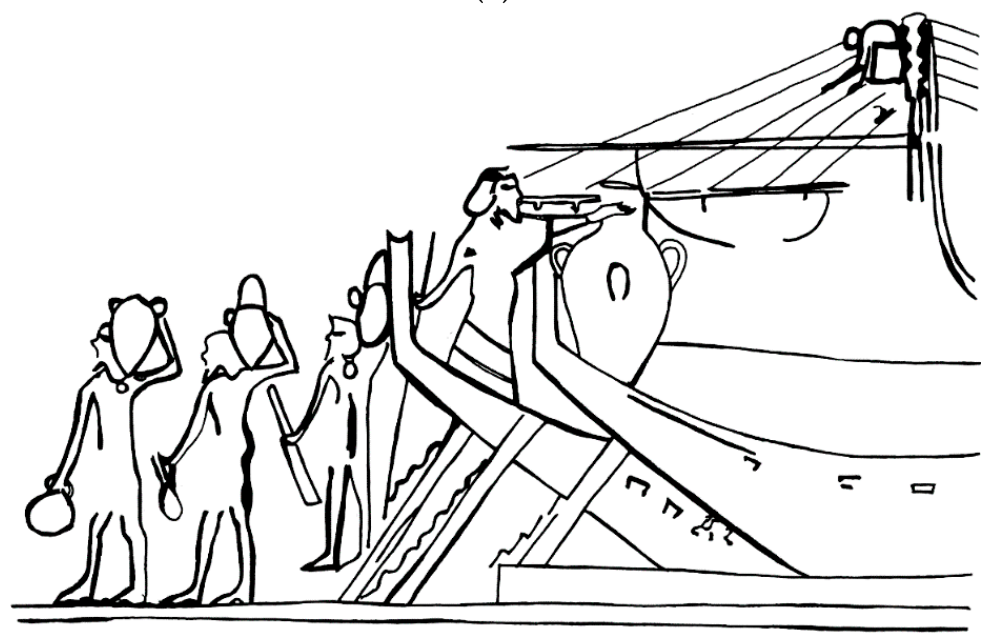

(b)

Figure 51. (a) Line drawing of a scene of hybrid ships from the tomb of Iniwia. Late XVIIIth or early XIXth Dynasty. Note the hogging truss (arrows). From (Wachsmann 1998, p. 60 figure 3.30).

(b) Line drawing of Syrian ships from the tomb of Kenamun (see Figure 5), reversed horizontally. From (Wachsmann 1998, p. 59 figure 3.30: B).

However, together with these Egyptian details, Iniwia's scene also contains elements typical of the Syro-Canaanite vessels in the tombs of Kenamun and Nebamun (Figures 4, 5 and 9b) (Wachsmann 1998, pp. 42-47, 54-60). The ships in the scenes from the tombs of Kenamun and Iniwia are unique in contemporaneous Egyptian art in depicting a crows' nest fastened to the forward sides of their masts

29 On hogging trusses and the question of keels on Egyptian seagoing ships, see (Hocker 1998a; Wachsmann 1998, pp. 14-15, $18,24-26,45,56,74,228$ figure $10.9,242,248-250,367$ no. 15,346 no. 55 , and there additional bibliography). 
and with pithoi nestled in the bows. Indeed, the former element only appears on Syro-Canaanite ships prior to the 12th century BC: subsequently, they top the masts of both the Egyptian and Sea Peoples' ships at Medinet Habu (Figures 14-18). Three ships appear in the Iniwia scene as opposed to two in the Kenamun one, but the latter scene depicts three boarding ladders. Iniwia's vessels carry fencing above the sheer, similar to those already discussed on the Kenamun ships and also carried by the vessel that wrecked at Uluburun (Figures 4, 5 and 8). Each ship in the Iniwia relief has a large pithos stored in her bow. Pithoi appear on the Kenamun ships and ten have been recovered at Uluburun (Pulak 2008, p. 290 figure 1; 296, 321-322, 379). The ships in both scenes of Kenamun and of Iniwia carry six lifts on either side of their masts, as opposed to the eight depicted on Hatshepsut's Punt ships. Porters offload Canaanite jars in both scenes.

Despite all of these similarities, might Iniwia's vessels represent actual Egyptian seagoing ships that have adopted elements of Syro-Canaanite ships? Following the reign of Hatshepsut iconographic evidence for Egyptian seagoing ships stops. As noted, the Medinet Habu naval battle took place on a branch of the Nile, so, although these vessels combat invading seagoing ships, the Egyptian vessel depicted might not have been meant for the open sea (Figures 14-16: Ships E.1-4). Furthermore, Canaanite influence is clear in the Egyptian shipyard records from Prw nfr (BM 10056), which date to the reign of Thutmose III, immediately following the reign of Hatshepsut (Glanville 1931, 1932; Wachsmann 1998, pp. 51-52).

The similarities between the Kenamun and Iniwia scenes, which verge on the subliminal, indicate that the issue here is one of artistic creativity rather than one of changes to actual ships despite the initial attractiveness of such an interpretation. Note the parts of the Kenamun scene isolated in Figure 52 with some of these details horizontally reversed in Figure $51 \mathrm{~b}$ to correspond in direction to the elements of Iniwia's scene (a). A comparison of the two scenes reveals a remarkable additional relationship. In the Kenamun scene, note the scribe and the figure with his head and right shoulder hidden behind the bow of a ship at the upper right corner of Figure 52 and enlarged in Figure 53a,b (note that, for clarity, in Figure 53a I also have reversed the Kenamun-scene scribe.)

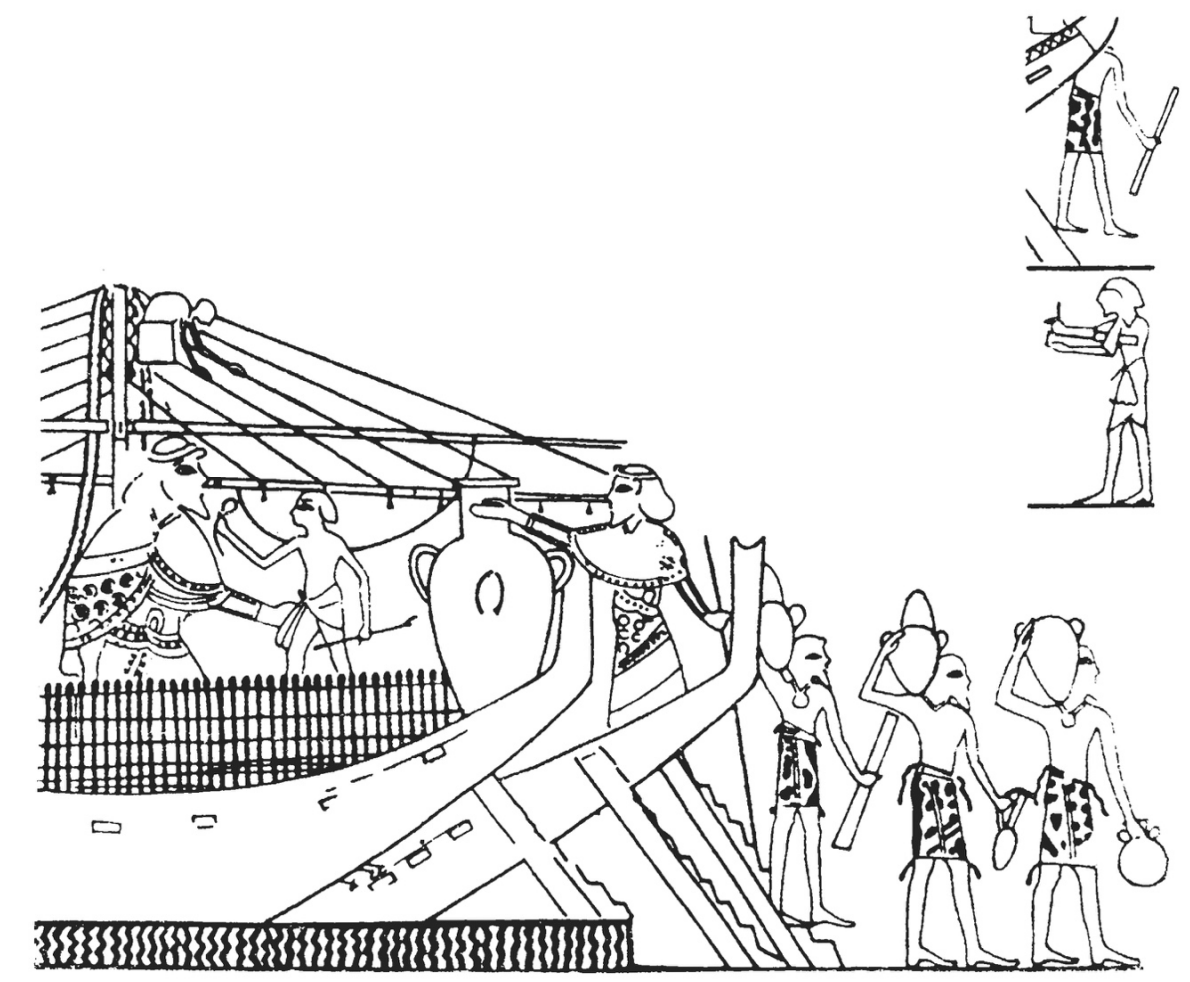

Figure 52. Detail of the scene from the tomb of Kenamun (Figure 5) with the parts appearing in Figures 51b and 53a,b blocked out. From (Wachsmann 1998, p. 58 figure 3.29). 


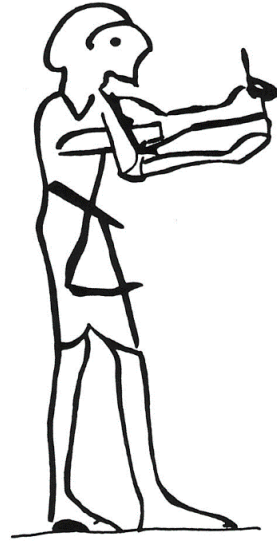

(a)

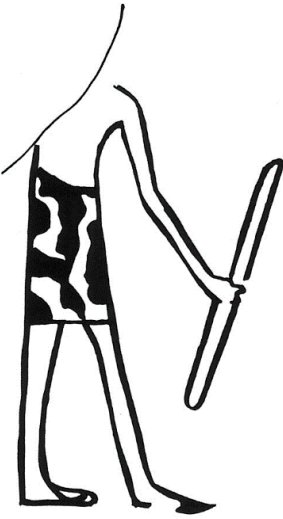

(b)

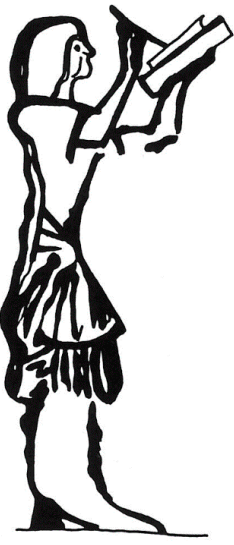

(c)

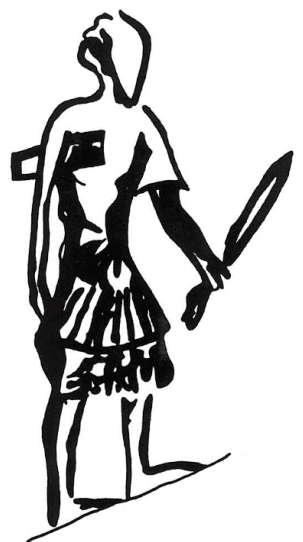

(d)

Figure 53. A comparison of figures in the nautical scenes from the tombs of Kenamun and Iniwia: (a) Scribe from the Kenamun scene (reversed); (b) Man with staff from the Kenamun scene; (c) Scribe from the Iniwia scene; and, (d) Egyptian official with staff from the Iniwia scene. Note that he carries the scribe's pen box under his arm. After (Wachsmann 1998, p. 60 figure 3.31).

Now, compare Kenamun's two figures with the Egyptian official, holding a staff, and the scribe in Iniwia's scene (Figures 44,51a and 53c,d ). The two pairs of figures are virtually identical but for their clothing. ${ }^{30}$ Kenamun's scribe holds his pen box under his right arm, but Iniwia's scribe has raised his arms as he writes, which precluded Iniwia's artist from positioning the pen box under his scribe's arm ... so the artist placed the penbox under the arm of his official (Figure 53a,c,d).

In fact, like my imaginary submarine icon, Iniwia's ships never actually existed in reality. Rather, his artist cleverly contrived imaginary ships by combining the details of two entirely different types of seagoing vessels. Any attempts to reconstruct an actual ship from this iconographic 'evidence' lack validity (Landström 1970, p. 139 figure 407).

The following example demonstrates how, when depicting vessels from literature, misinterpretations of terminology can also occur. The recent discovery of a scene depicting the story of Noah's ark (Genesis 6:9-22; 7:1-18) with animals displayed around it in the fifth-century AD synagogue at Huqoq in Israel brings attention to this curious genre in Late Antiquity (Magness et al. 2018, pp. 88 figure 26, 89 figure 27, 99 figure 36, 102, 103 figure 39; Magness et al. 2019, pp. 32-33). In the Huqoq Deluge scene, the ark has unfortunately been largely destroyed, but enough of it remains for the excavators to favorably compare it to the ark in a scene from a structure in Mopsuestia, Turkey, which has been identified as either a church or a synagogue (Budde 1960, pp. 121-24, 126; 1969, p. 109, figures 27, 28; Avi-Yonah 1982; Talgam 2014, p. 321 figure 397; Magness et al. 2018, pp. 102, 103 figure 39, 114-115; Magness et al. 2019, pp. 26-27, 32-33; Britt and Boustan 2019, pp. 3, 39, 43-45). ${ }^{31}$ Surprisingly, in both scenes Noah's ark appears as a box standing on four legs (Figure 54) (Magness et al. 2018, pp. 102, 103 figure 39; 2019, pp. 32-33).

30 On changes of clothing in Egyptian wall paintings, see (Pritchard 1951; Wachsmann 1987, pp. 44-48, and there additional references).

31 Although badly damaged, a third Deluge scene mosaic in the late-fifth century AD synagogue at Jerash, Jordan, may never have had an ark represented in it, rather focusing on the covenant the Lord made with Noah after the flood (Genesis 8:20-22, 9:1-17; Biebel 1938, pp. 319-22, pls. LXIII-LXIV; Talgam 2014, pp. 319, 320 figures 394-395, 321 figures 396-397). On the possible use of pattern books in creating Byzantine-period mosaics, see (Dauphin 1978). 


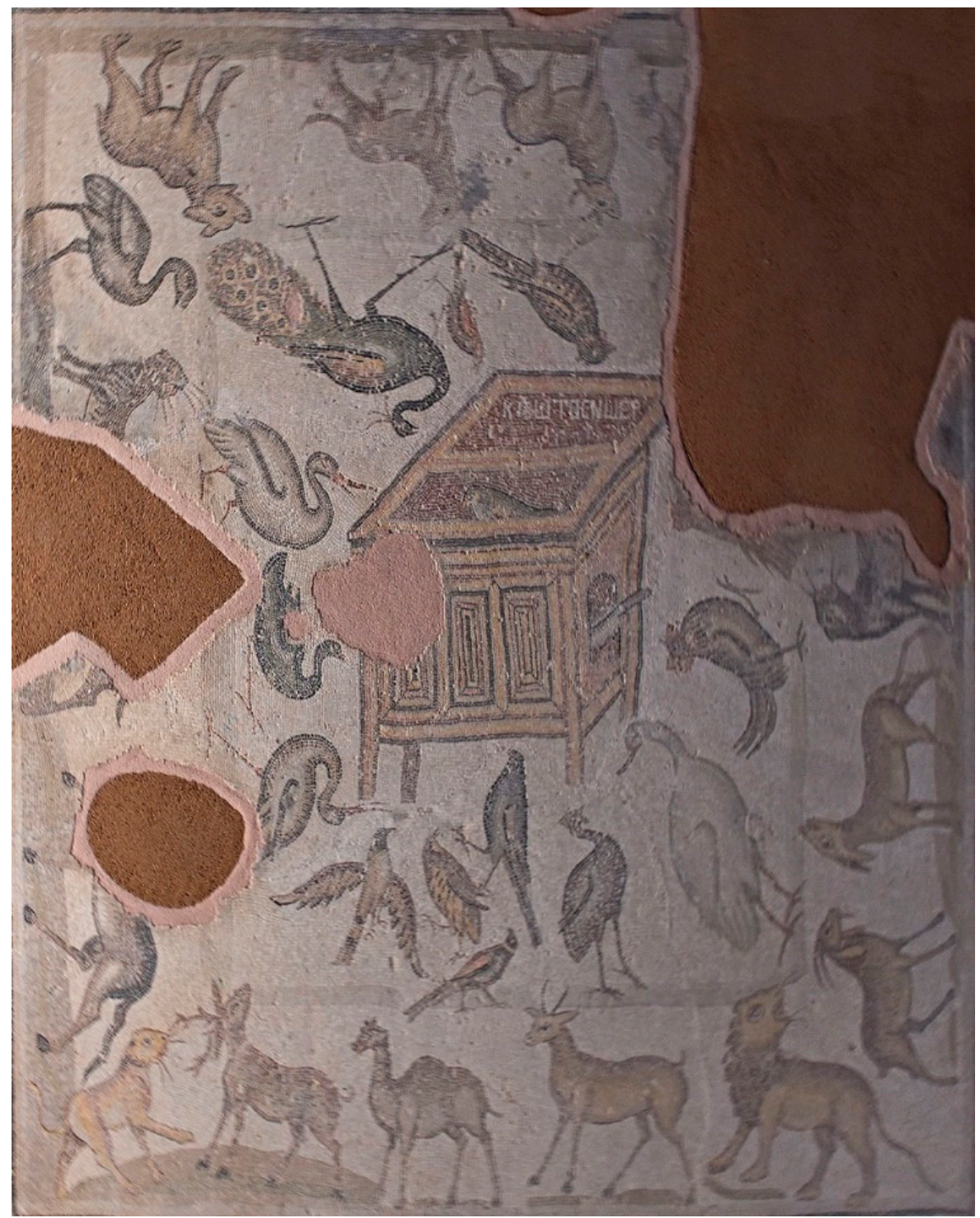

Figure 54. The Mopsuestia Noah scene. The ark appears as a box on four legs. Photo: D. Ossman. Wikimedia Commons. Accessed on 30 July 2019 (https://commons.wikimedia.org/wiki/File:Adana_ Archaeological_Museum_Noah\%27s_Ark_Mosaic_0338c.jpg). Used with permission.

Noah was one of numerous biblical figures seen as an expression of the Church, or of Jesus, by the early Church Fathers: they interpreted the Deluge cycle in terms of redemption and salvation (Spier 2007b, pp. 11-12; Talgam 2014, pp. 319, 321 fn. 301). For these reasons, the story commonly appears in early Christian art. In one of the earliest depictions of this kind, dating to the early fourth-century AD, Noah stands alone in a floating ark in the shape of a box (Jensen 2007, pp. 71, 72 figure 53). Similarly, the ark appears as a box with legs, three of which are visible, in the Ashburnham Pentateuch, dating to circa AD 500 (Kessler 2007, pp. 155, 156 figure 116). Other early examples of Noah's ark also depict it either as a square box, or as a box on legs, typically with the cover open (Goodenough 1953a, p. 120; 1953b, figure 701; Spier 2007a, pp. 172, 173 figure 2, 208 figure 40, 214 figure 44: B; Talgam 2014, p. 319 no. 289).

Indeed, the earliest known representations of a biblical scene depict Noah and his ark on an extraordinary series of coins, which spanned the reigns of Septimius Severus (AD 193-211) to Trebonianus Gallus (AD 251-253), from the ancient site of Apamea Kibotos, today's Dinar, in western Turkey (Friedländer and Sallet 1877, pp. 225-26, pl. IX, no. 885; Gressmann 1926-1927, vol. 2, p. 167, 
pl. CCXXVIII, no. 601; Gressmann 1980, p. 172; Goodenough 1953a, pp. 119-20; 1953b, figure 700; Trebilco 1991, pp. 86-88, 92-95; Spier 2007a, catal. 171, figure 1: B, and there additional references).

The example in Figure 55 dates to the rule of the Roman Emperor Philip the Arab (Marcus Julius Philippus Augustus, AD 244-249) (Friedländer and Sallet 1877, pp. 225-26, pl. IX, no. 885). On the coin's reverse, Noah and his wife stand inside the ark, again in the shape of an open box inscribed with the name Noah in Greek (N $\Omega E$ ), floating on water. Above the 'ark's' cover, on the left, a dove bears an olive branch while a raven perches on the cover (Genesis 6:6-12). ${ }^{32}$ On the left, Noah and his wife stand on dry land with their hands raised in the orans position (Trebilco 1991, pp. 87, 94-95).

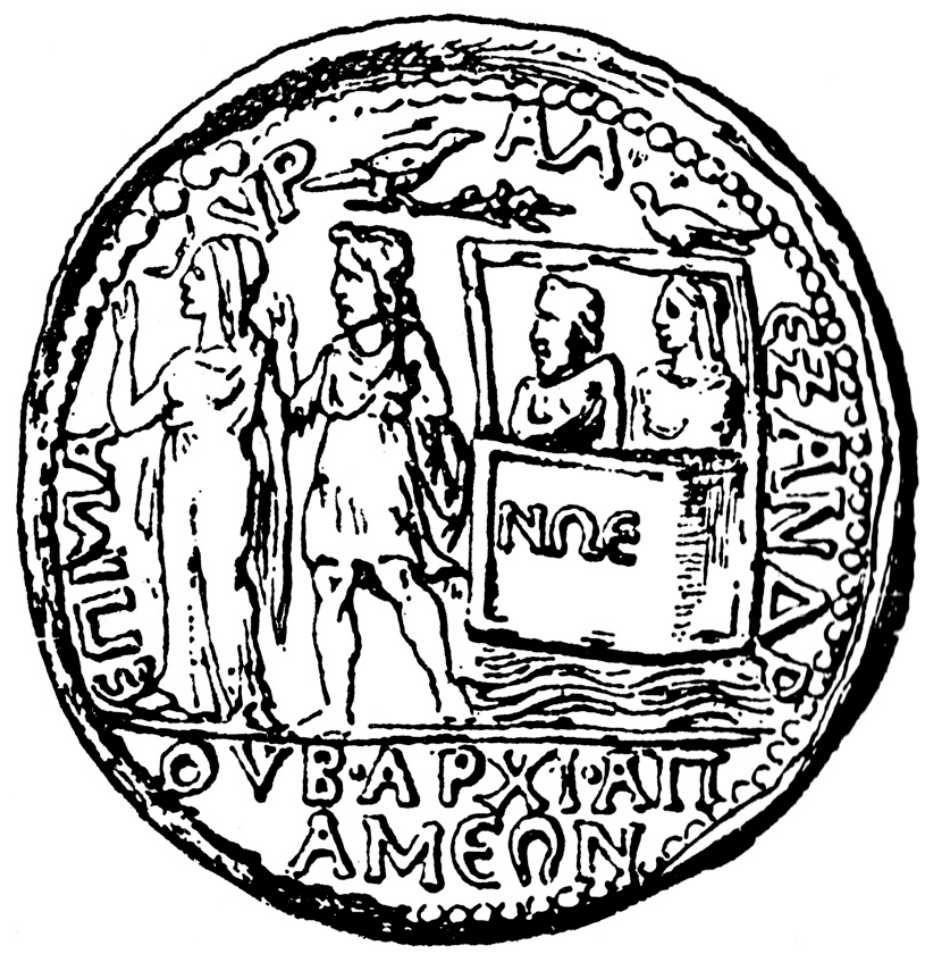

Figure 55. A coin from Apamea depicting Noah and his wife with the ark, in the shape of a box in the background. The name Noah appears in Greek (N $\Omega$ E) on the box. Reign of Philip the Arab (Marcus Julius Philippus Augustus, AD 244-249). From (Gressmann 1926-1927, vol. 2, pl. CCXXVIII, no. 601).

The scene might have been attractive to the Apameans due to their city's epithet, kibotos meaning box, as discussed below, is the same term used for Noah's ark by the Septuagint, the Pentateuch part of which was compiled in the third century BC (Trebilco 1991, pp. 90-91). Additionally, its appearance here might relate to the tradition that located Mount Ararat, where the ark landed after the flood, in the region of Apamea (Sibylline Oracles I:240-324; Trebilco 1991, pp. 95-99). This city had a large Jewish population, which served presumably as the source from whom the city luminaries learned of the story (pp. 85-103).

Relations must have been good between the Jews and their Greek neighbors in Apamea, as Josephus (War 2:479) includes it among only a handful of Greek cities that did not attack, or imprison, their local Jewish population at the outset of the Jewish War in AD 66. Additionally, the Council of Laodicea, which apparently met in the latter half of the fourth-century AD, and whose decisions embody the circumstances in Phrygia in general and its capital, Apamea, in particular, include

32 While not obvious on the coin in Figure 55, better preserved coins from this series show the bird with a raven's beak (Spier 2007a, catal. 171, figure 1: B). 
injunctions against Jewish influence, which points to this being a concern for the Church at that time (Trebilco 1991, pp. 101-3).

Irrespective of whether Noah's ark ever existed, I suspect that today all can agree that it would not have been a box on legs! And yet-no doubt about it-Jews, Christians, and even pagans, conceived of the ark in the period covered by the representations discussed above as a box. ${ }^{33}$ How are we to explain this oddity?

Paul R. Trebilco (1991, p. 87 no. 7), following earlier writers, suggests that the coins continue a tradition set by Hellenic artisans depicting some mythological characters-Auge and Telephus or Danaë and Perseus-on the sea in boxes. While this explanation is possible, neither of these myths deal with a flood story, but they rather describe the attempted murder of a mother and son by drowning in a box set upon the sea (Graves 1988, p. 188 §141: G, no. 9, 238 §73: C, no. 4, with references).

In the Mopsuestia scene, the inside cover of the open box bears the inscription "KIB $\Omega T O \Sigma N \Omega E$ P", which Michael Avi-Yonah (1982, p. 186) renders as "the ark of Noah the R[edeemer]", or alternately as "the r[edeeming] ark of Noah" (Figure 54). In the Hebrew bible, the same term that was used for the "ark" of Noah (תיבה] [tievah]) was also employed to describe the basket in which the baby Moses was set adrift on the Nile River (Exodus 2:3,5-6). This term perhaps derives from $t u b b \hat{u}$, a type of Babylonian vessel (Finkel 2014, pp. 147-49, 152-53, 313-14). Similarly, in the original Hebrew the term ארון (aron) designates the "Ark" of the Covenant and the same term applies to Joseph's coffin (Exodus 2:3). Thus, in the Hebrew version, a single term serves for floating vessels in which something can be stored (Noah and Moses), while a second term describes a storage device, like the Ark of the Covenant: alternately, the former term might refer to something in which living persons can dwell, while the latter is for the storage of inanimate objects or deceased humans (Klein 2016).

The terminology changes in the Septuagint, which consistently employs the Greek term $\kappa \iota ß \omega \tau$ ¿ó $\varsigma$ - meaning an enclosed wooden container that is used to store valuable objects-for both Noah's ark as well as for the Ark of the Covenant. The Septuagint also employs the same term in describing the wooden box that the Lord instructed Moses to build for the two stone tablets containing the Ten Commandments (Deuteronomy 10:1-3, 5), while the term $\theta \tilde{\imath} \beta \iota \varsigma$ (basket) serves for Moses' mode of transport on the Nile (Muraoka 2009, pp. 330, 397). ${ }^{34}$

In the Rabbinic literature, the two terms-are used almost synonymously (Klein 2016). The Mishna, which was codified by Rabbi Yehuda ha-Nassi in the early third century AD, clearly uses תיבה to denote something of religious significance that has nothing to do with water (Ta'anit 2:1; Megillah 3:1), perhaps referring to a movable structure in which Torah scrolls were stored in a synagogue. Furthermore, Talmud Yerushalmi (Shekalim 6:1), which was compiled in the late fourth century AD, describes the Ark (ארון) of the Covenant's components as consisting of three tievahs (that is, boxes) nested one inside another.

It seems that the rather strange- - to the modern mind-concept of depicting Noah's ark as a box may derive from these later terminological evolutions.

\section{Conclusions}

Shipwrecks and seafaring transformed ancient rivers, lakes, seas, and oceans from formidable barriers into superhighways of cultural interaction. The archaeology of shipwrecks and hull reconstruction provide an understanding of ancient vessels, but only tell part of the story. We simply lack shipwrecks for some

33 On the information to be gleaned on hull construction techniques from the cognate story of Utnapishtim, the Mesopotamian flood survivor from the Epic of Gilgamesh, see (Pedersen 2003; 2005).

34 Noah's Ark: Genesis 6: 14-16, 18. The Ark of the Covenant: Exodus 25: 10, 13-15, 16, 21-22, 26: 33-34, 30: 6, 26, 31: 7, 35: 12, 37: 1, 5, 39: 35, 40: 3, 5, 20-21; Leviticus 16: 2; Numbers 3: 31, 4: 5, 8: 89, 10: 33, 35, 14: 44; Deuteronomy 10: 8, 31: 9, 25, 26; Joshua 3: 3-4, 6, 8, 11, 13-15, 17, 4: 7, 9-11, 16, 18, 6: 4, 6-9, 11-13, 7: 6, 9: 33; Judges 20: 27; I Samuel 3: 3, 4: 3-6, 11, 13, 17-19, 21, 5: 1-4, 7-8, 10-12, 6: 1-3, 8, 11, 13, 15, 18-21; 7: 1-2, 14: 18; II Samuel 6: 2-4, 6-7, 9, 10-13, 15-17, 7: 2, 11: 11, 15: 24-25, 15: 25, 29; I Kings 2: 26, 3: 15, 6: 19, 8: 1, 3, 5-7, 9, 21; I Chronicles 6: 31; 13: 3, 5-7, 9-10, 13-14, 15: 1-3, 12, 14-15, 23-29, 16: 1, 4, 6, 37, 17: 1, 22: 19, 28: 2, 18; II Chronicles 1: 4, 5: 2, 4-10, 6: 41, 8: 11, 35: 3; Psalms 132: 8; Jeremiah 3: 16. 
epochs and cultures. Additionally, once a vessel reaches the seafloor, normally little survives of its upper parts that remain exposed in the water column. Due to this, nautical archaeology primarily focuses on the remaining lower parts of hulls and their contents. Thus, the study of ships in ancient art represents a vital source for missing physical information that would otherwise be irretrievably lost.

'Art ships' can vary markedly from their prototypes. Vessels depicted in art are not actual craft, but rather representations created by individuals of varying artistic capabilities. In any given setting, the same type of ship could be represented in two or three-dimensional formats in multiple mediums by persons of differing ability, artistic expertise, or knowledge of the vessel itself. Method, material, space available, and purpose of the image could all influence the outcome. Watercraft in art can also deviate from the original in the proportionality of their parts and related items, including that of humans to the hull. Therefore, it is important to begin study of a corpus of ship art with the most detailed examples available before approaching more problematic imagery.

Introducing the researcher's (often invisible) own biases into the complex work of interpretation must be avoided. Adhering closely to the principle of Occam's Razor (preferring the simplest solution) remains the best method of preventing unforced errors, while cultural continua can serve as useful guides.

A study of ship iconography must begin by collecting all evidence that might reasonably contribute to its interpretation, including texts, archaeology, and ethnographical parallels. The value of most ship depictions depends on the amount of information that can be derived from them. The relationship of human figures to a ship's architecture in some cases can provide information regarding the structure and details of the depicted vessel.

The original source of the vessel's representation should be addressed. Is the image based on first-hand observation or has it been copied from one or more previous iterations? Had the artist actually seen the physical prototype vessel reproduced? Careful attention should be addressed to the question of artistic accuracy. Has the artist misinterpreted, added, or removed details from the depiction?

Where possible, ancient ship art should be examined firsthand. Did a ship representation undergo any changes due to issues of conservation, interpretation, or display between the time of its discovery and the engagement of the researcher? This question also holds true for published drawings: do they accurately reflect the original, or have details been added to, or subtracted from, them?

In many cases, typologies can be useful in understanding vessels in art. However, the painting of ships can prove to be less amenable to detailed classification than the pots on which they appear as the latter are physical objects, while the former are once removed, being representations of physical objects. In extreme cases, some ships represented in art depict vessels that never actually existed.

From personal experience, I can attest that discovering insights regarding seafaring in bygone days through the careful study of ancient ship iconography can be just as exciting and gratifying as discovering ancient shipwrecks underwater ... and well worth the effort.

Funding: This research received no external funding.

Acknowledgments: I thank Cemal Pulak for his assistance with the list of excavated shipwrecks found inverted and Harry Tzalas for his help in various aspects of this paper. I appreciate the many useful comments that I received from Aleydis Van de Moortel and the two other anonymous peer reviewers of this manuscript. Megan Hagseth, my Graduate Research Assistant, has been of great assistance in preparing this manuscript. I also am grateful to Olivia Brill, a PhD candidate in Texas A\&M University's Nautical Archaeology Program. One day Olivia came to my office and asked me bluntly, "How can I interpret ancient ship iconography?" Her question made me realize, for the first time, that a paper on this topic might be useful. I wrote this article while serving as the Meadows Professor of Biblical Archaeology in the Nautical Archaeology Program at Texas A\&M University. I am grateful to George F. Bass, the Meadows Foundation of Dallas, the Institute of Nautical Archaeology and to Texas A\&M University for making this possible.

Conflicts of Interest: The author declares no conflict of interest. 


\section{Appendix A Glossary of Nautical Terms}

As some readers of this journal may be unfamiliar with nautical terms, I have endeavored to minimize my use of them. Some terms, however, are unavoidable when trying to convey this subject matter. The glossary below contains concise descriptions of the meanings as they apply here. For more detailed nautical glossaries, see (Steffy 1994, pp. 266-98; Casson 1995, pp. 389-402 [Greek and Latin nautical terms]; Hocker 1998b).

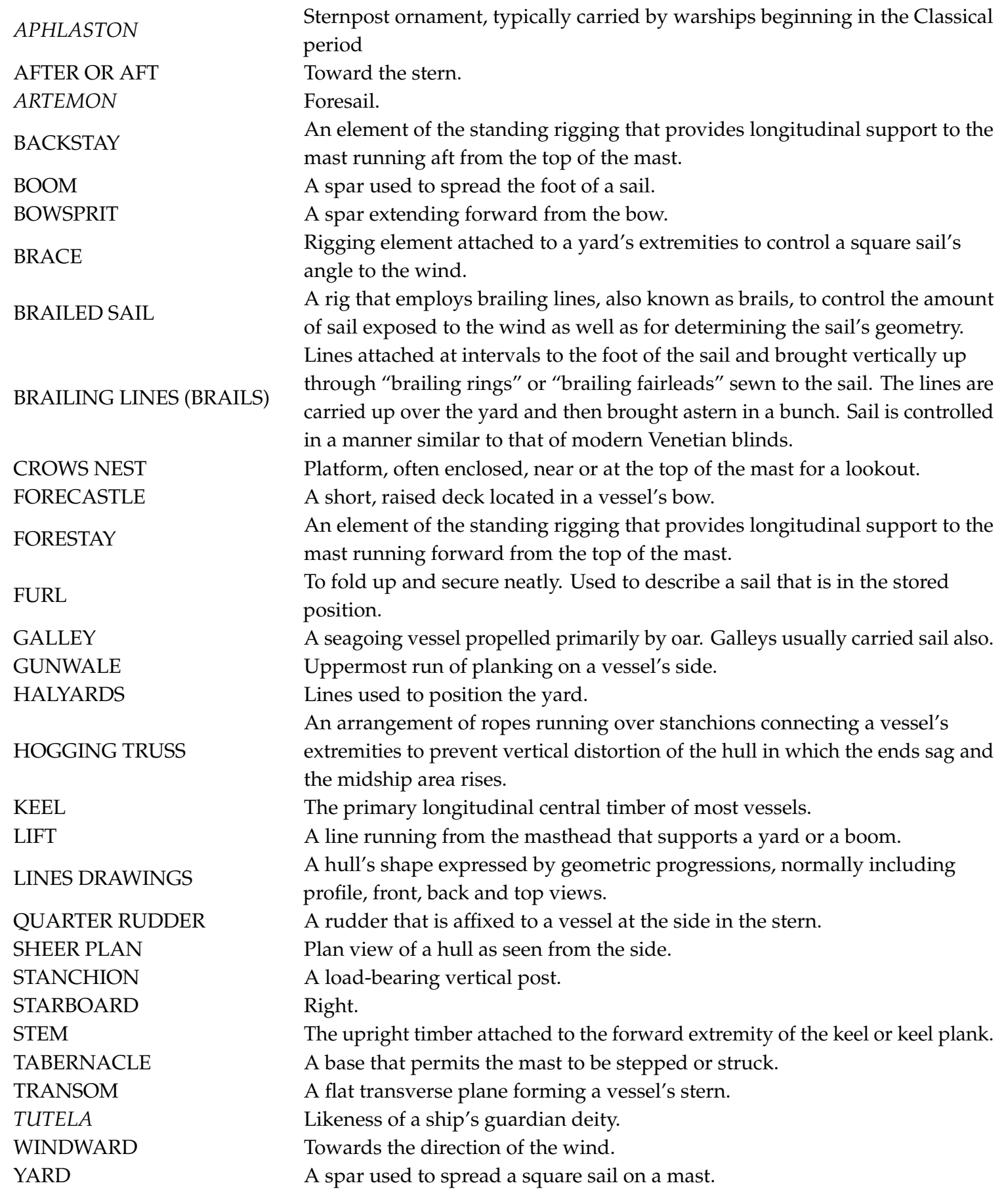




\section{References}

Avi-Yonah, Michael. 1982. The Mosaics of Mopsuestia-Church or Synagogue? In Ancient Synagogues Revealed. Edited by Lee I. Levine. Jerusalem: Israel Exploration Society, Detroit: Wayne State University Press, pp. 186-90.

Bachhuber, Christoph. 2013. Review: The Gurob Ship-Cart Model and Its Mediterranean Context by Shelley Wachsmann. INA Quarterly 40: 28-29.

Ballard, Robert Duane. 2001. Deep Black Sea. National Geographic Magazine 199: 52-69.

Ballard, Robert Duane, Ann Margaret McCann, Dana Yoerger, Louis Whitcomb, David Mindell, John Oleson, Hanumant Singh, Brendon Foley, John Adams, Dennis Piechota, and et al. 2000. The Discovery of Ancient History in the Deep Sea Using Advanced Deep Submergence Technology. Deep-Sea Research I 47: 1591-620. [CrossRef]

Basch, Lucien. 1975. Another Punic Wreck in Sicily: Its Ram 1. A Typological Sketch. International Journal of Nautical Archaeology 4: 201-19. [CrossRef]

Basch, Lucien. 1978. Le navire mnš et autres notes de voyage in Égypte. Mariner's Mirror 64: 99-123. [CrossRef]

Basch, Lucien. 1987. Le musée imaginaire de la marine antique. Athens: Hellenic Institute for the Preservation of Nautical Tradition.

Basch, Lucien, and Michal Artzy. 1985. App. 2. Ship Graffiti at Kition. In Excavations at Kition V: I: The Pre-Phoenician Levels, Areas I and II. Edited by Karageorghis Vassos and M. Demas. Nicosia: Department of Antiquities, pp. 322-36.

Bascom, Willard. 1976. Deep Water, Ancient Ships: The Treasure Vault of the Mediterranean. Garden City: Doubleday \& Company, Inc.

Bass, George Fletcher, ed. 1967. Cape Gelidonya: A Bronze Age Shipwreck. Transactions of the American Philosophical Society, N.S 57: 8. Philadelphia: American Philosophical Society.

Bass, George Fletcher. 1972. The Earliest Seafarers in the Mediterranean and the Near East. In A History of Seafaring Based on Underwater Archaeology. Edited by George F. Bass. New York: Walker and Company, pp. 11-36.

Bass, George Fletcher. 1976. Archaeology Beneath the Sea. New York: Harper Colophone Books.

Bass, George F. 1987. Oldest Known Shipwreck Reveals Bronze Age Splendors. National Geographic Magazine 172: 693-733.

Beaux, Nathalie. 1990. Le cabinet de curiosités de Thoutmosis III. Orientalia Lovanensia Analecta 36. Louvain: Dép. Oriëntalistiek.

Benson, Jack L. 1961. A Problem in Orientalizing Cretan Birds: Mycenaean or Philistine Prototypes? Journal of Near Eastern Studies 20: 73-84, pls. 3-6. [CrossRef]

Benson, Jack L. 1975. Birds on Cypro-Geometric Pottery. In The Archaeology of Cyprus: Recent Developments. Edited by N. Robertson. Park Ridge: Noyes Press, pp. 129-50.

Betts, John H. 1968. Trees in the Wind on Cretan Sealing. American Journal of Archaeology 72: 149-50, pl. 61. [CrossRef]

Betts, John H. 1973. Ships on Minoan Seals. In Marine Archaeology, Paper presented at the Twenty-Third Symposium of the Colston Research Society, University of Bristol, Bristol, UK, April 4-8. Edited by D. J. Blackman. London: Archon Books, pp. 325-38.

Bianchi, Robert S. 1997. The Theban Landscape of Rameses II. In Ancient Egypt, The Aegean and the Near East: Studies in Honor of Martha Rhoads Bell. Edited by Jack Phillips. San Antonio: Van Siclen Books, pp. 87-94.

Biebel, F. M. 1938. The Mosaics. In Gerasas: City of the Decapolis. Edited by Carl H. Kraeling. New Haven: American Schools of Oriental Research, pp. 297-352.

Boardman, John. 1967. The Khaniale Tekke Tombs, II. Annual of the British School at Athens 62: 57-75, pls. 7-17. [CrossRef]

Bodenheimer, Shimon Fritz. 1949. Animal Life in Biblical Lands: From the Stone Age to the End of the Nineteenth Century. Jerusalem: Bialik Institute, vol. I. (In Hebrew)

Bodenheimer, Shimon Fritz. 1960. Animal and Man in Bible Lands: Text. Collection de travaux de l'Académie international d'histoire des sciences 10. Lieden: E.J. Brill.

Bodenheimer, Shimon Fritz. 1972. Animal and Man in Bible Lands: Figures and Plates. Collection de travaux de l'Académie international d'histoire des sciences 10. Lieden: E.J. Brill. 
Breasted, James Henry, ed. 1988. Ancient Records of Egypt. 5 vols, London: Histories \& Mysteries of Man Ltd, (Reprint).

Brennan, Michael L., Dan Davis, Chris Roman, Ilya Buynevich, Alexis Catsambis, Meko Kofahl, Derya Ürkmez, J. Ian Vaughn, Maureen Merrigan, and Muhammet Duman. 2013. Ocean Dynamics and Anthropogenic Impacts along the southern Black Sea Shelf Examined through the Preservation of Pre-Modern Shipwrecks. Continental Shelf Research 53: 89-101. [CrossRef]

Britt, Karen, and Raanan Boustan. 2019. Artistic Influences in Synagogue Mosaics: Putting the Huqoq Synagogue in Context. Biblical Archaeology Review 45: 39-45, 68.

Broad, William J. 2016. 'We Couldn't Believe Our Eyes:' A Lost World of Shipwrecks is Found. New York Times. November 12. Available online: http://www.nytimes.com/2016/11/12/science/shipwrecks-black-seaarchaeology.html?_r=0 (accessed on 21 August 2019).

Bruni, Stefano, and Marta Abbado. 2000. Le Navi Antiche di Pisa: Ad un anno Dall'inizio delle Ricerche. Firenze: Editizioni Polistampa.

Budde, Ludwig. 1960. Die frühchristlichen Mosaiken von Misis-Mopsuhestia in Kilikien. Pantheon 18: 116-26.

Budde, Ludwig. 1969. Antike Mosaiken in Kilikien. Recklinghausen: Aurel Bongers, vol. I.

Camilli, Andrea, and Elisabetta Setari, eds. 2005. Ancient Shipwrecks of Pisa: A Guide. Milano: Soprintendenza per i Beni Archeologici della Toscana and Mondadori Electa S.p.A.

Cariolou, Glafkos A. 1997. KYRENIA II: The Return from Cyprus to Greece of the Replica of a Hellenic Merchant Ship. In Res Maritimae: Cyprus and the Eastern Mediterranean from Prehistory to Late Antiquity, Paper presented at the Second International Symposium "Cities on the Sea", Nicosia, Cyprus, October 18-22. Cyprus American Archaeological Research Institute Monograph Series; vol. 1, Edited by Stuart Swiny, Robert L. Hohlfelder and Helena Wylde Swiny. Atlanta: Scholars Press, pp. 83-97.

Carter, Tristan, Daniel A. Contreras, Justin Holcomb, Danica D. Mihailović, Panagiotis Karkanas, Guillaume Guérin, Ninon Taffin, Dimitris Athanasoulis, and Christelle Lahaye. 2019. Earliest Occupation of the Central Aegean (Naxos), Greece: Implications for Hominin and Homo Sapiens' Behavior and Dispersals. Science Advances 5. Available online: https://advances.sciencemag.org/content/5/10/eaax0997 (accessed on 27 October 2019). [CrossRef] [PubMed]

Casson, Lionel. 1975. Bronze Age Ships. The Evidence of the Thera Wall Paintings. International Journal of Nautical Archaeology 4: 3-10. [CrossRef]

Casson, Lionel. 1995. Ships and Seamanship in the Ancient World. Reprint with addenda and corrigenda 1971. Baltimore and London: Johns Hopkins University Press.

Coldstream, John Nicolas. 2006. Geometric Greece: 900-700 BC. London: Routledge.

Coleman, John E. 1985. "Frying Pans" of the Early Bronze Age Aegean. American Journal of Archaeology 89: 191-219, pls. 33-37. [CrossRef]

Corbo, Virgilio P. 1978. Piazza e villa urbana a Magdala. Liber Annuus 28: 232-40, pls. 71-76.

Dakoronia, Fanouria. 1990. War-Ships on Sherds of LH IIIC Kraters from Kynos. In Tropis, Paper presented at the 5th International Symposium on Ship Construction in Antiquity, Delphi, Greece, August 27-29. Edited by Harry Tzalas. Athens: Hellenic Institute for the Preservation of Ship Construction in Antiquity, vol. II, pp. 117-22.

Dakoronia, Fanouria. 1995. Editor's Note (War-Ships on Sherds of LH IIIC Kraters from Kynos?). In Tropis, Paper presented at the 3rd International Symposium on Ship Construction in Antiquity, Athens, Greece, August 24-27. Edited by Harry Tzalas. Athens: Hellenic Institute for the Preservation of Ship Construction in Antiquity, vol. III, pp. 147-48.

Dakoronia, Fanouria. 2006. Mycenaean Pictorial Style at Kynos, East Lokris. In Pictorial Pursuits: Figurative Painting on Mycenaean and Geometric Pottery. Papers from Two Seminars at the Swedish Institute at Athens in 1999 and 2001. Edited by Eva Rystedt and Berit Wells. Stockholm: Svenska Institutet i Athen, pp. 23-29.

Danelius, Eva, and Heinz Steinitz. 1967. The Fishes and Other Aquatic Animals on the Punt-Reliefs at Deir El-Bahri. Journal of Egyptian Archaeology 53: 15-24.

Daressy, George. 1895. Une flottille phénicienne d'apres une peinture récente. Revue Archéologique 27: 286-92, pls. XIV-XV.

Dauphin, Claudine. 1978. Byzantine Pattern Books: A Re-examination of the Problem in the Light of the "Inhabited Scroll". Art History 1: 400-23. [CrossRef]

Davies, Nina, and Norman de Garis Davies. 1933. The Tombs of Menkheperrasonb, Amenmose, and Another. Theban Tombs Series V; London: The Egypt Exploration Society. 
Davies, Norman de Garis. 1930. The Egyptian Expedition: The Work of the Graphic Branch of the Expedition. Bulletin of the Metropolitan Museum of Art 25: 29-42. [CrossRef]

Davies, Norman de Garis. 1943. The Tomb of Rech-mi-rē' at Thebes. Publications of the Metropolitan Museum of Art Egyptian Expedition XI. New York: Metropolitan Museum of Art, vol. II.

Davies, Norman de Garis, and Raymond Oliver Faulkner. 1947. A Syrian Trading Venture in Egypt. Journal of Egyptian Archaeology 33: 40-6, pl. VIII. [CrossRef]

Dothan, Trude. 1982. The Philistines and Their Material Culture. New Haven and Jerusalem: Yale University Press and Israel Exploration Society.

Doumas, Christos. 1983. Thera: Pompeii of the Ancient Aegean. London: Thames and Hudson.

Doumas, Christos. 1992. The Wall-Paintings of Thera. Translated by Alex Doumas. Athens: The Thera Foundation.

Doyle, Noreen. 1998. Iconography and the Interpretation of Ancient Egyptian Watercraft. Master's thesis, Texas A\&M University, College Station, TX, USA.

Dunand, Maurice. 1937. Fouilles de Byblos: 1926-1932 Atlas. Paris: Librairie orientaliste Paul Geuthner, vol. I.

Dunand, Maurice. 1939. Fouilles de Byblos: 1926-1932 Text. Paris: Librairie orientaliste Paul Geuthner, vol. I.

Edgerton, William F., and John A. Wilson. 1936. Historical Records of Ramses III: The Texts in Medinet Habu. 2 vols, Translated with Explanatory Notes. The Oriental Institute of the University of Chicago Studies in Ancient Oriental Civilization No. 12. Chicago: The Oriental Institute, University of Chicago.

Rainey, Anson Frank, and William M. Schniedewind. 2015. The El-Amarna Correspondence: A New Edition of the Cuneiform Letters from the Site of El-Amarna Based on Collations of All Extant Tablets. 2 vols, Handbook of Oriental Studies 110; Leiden: Brill.

Epigraphic Survey. 1930. Medinet Habu: Earlier Historical Records of Ramses III. Chicago: The University of Chicago Press, vol. I.

Evans, Arthur. 1964. The Palace of Minos. 4 vols, London: Biblo and Tannen, (Reprint).

Février, James G. 1949-1950. L'ancienne marine phénicienne et les découvertes récentes. La Nouvelle Clio 1-2: 128-43.

Finkel, Irving. 2014. The Ark Before Noah: Decoding the Story of the Flood. New York: Doubletree.

Friedländer, Julius, and Alfred von Sallet. 1877. Das königliche Münzkabinet. Berlin: Weidmannsche Buchhandlung.

Frost, Honor. 1969a. The Stone Anchors of Byblos. Melanges de l'Université Saint-Joseph, Beyrouth 45: 425-43, pls. I-VII.

Frost, Honor. 1969b. The Stone Anchors of Ugarit. Ugaritica 6: 235-45.

Frost, Honor. 1991. Anchors Sacred and Profane: Ugarite-Ras Shamra, 1986: The Stone Anchors Revised and Compared. In Ras Shamra-Ougarit VI: Arts et Industries de la Pierre. Edited by Marguerite Yon. Paris and Lyon: Editions Recherche sur les Civilisations and Maison de l'Orient, pp. 355-410.

Furumark, Arne. 1941. The Mycenaean Pottery: Analysis and Classification. Stockholm: Kungl. Vitterhets, Historie och Atikvitets Akademien.

Glanville, Stephen Ranulph Kingdon. 1931. Records of a Royal Dockyard of the Time of Thutmose III: Papyrus Museum 10056: Part I. Zeitschrift für Agyptische Sprache und Altertumskund 66: 105-21.

Glanville, Stephen Ranulph Kingdon. 1932. Records of a Royal Dockyard of the Time of Thutmose III: Papyrus Museum 10056: Part II. Commentary. Zeitschrift für Agyptische Sprache und Altertumskund 68: 7-41.

Goldstein, E. Bruce, ed. 2010. Encyclopedia of Perception. Thousand Oaks: Sage Publications, Ltd, vol. I.

Goodenough, Erwin Ramsdell. 1953a. Jewish Symbols in the Greco-Roman Period. The Archaeological Evidence from the Diaspora. Bollinger Series 37; New York: Pantheon Books, vol. 2.

Goodenough, Erwin Ramsdell. 1953b. Jewish Symbols in the Greco-Roman Period. Illustrations. Bollinger Series 37; New York: Pantheon Books, vol. 3.

Grattan, David W. 1987. Waterlogged Wood. In Conservation of Marine Archaeological Objects. Edited by Colin Pearson. London: Butterworths, pp. 55-67.

Graves, Robert. 1988. The Greek Myths. 2 vols, Harmondsworth: Penguin, (Reprint).

Gray, Dorothea. 1974. Seewessen. Archaeologia Homerica. Bd. 1, Kapitel G. Göttingen: Vandenhoeck und Reprecht. Gressmann, Hugo. 1926-1927. Altorientalische Texte Zum Alten Testament. 2 vols, Berlin and Leipzig: De Gruyter.

Gressmann, Hugo. 1980. Jewish Life in Ancient Rome. In Jewish Studies in Memory of Israel Abrahams by the Faculty and Visiting Teachers of the Jewish Institute of Religion. Edited by the Alexander Kohut Memorial Foundation. New York: Arno Press, pp. 170-91.

Grimal, Nicholas-Christophe. 1992. A History of Ancient Egypt. Oxford and Cambridge: Blackwell. 
Guttandin, Thomas. 2009. Vom Einbaum zum Plankeschiff: “Geschnäbelte” Boote als Konstruktionsprinzip im mittelminoischen Schiffsbau. Skyllis (Deutsche Gesellschaft zur Förderung der Unterwasserarchäeologie e.V.) 9: 124-37.

Guttandin, Thomas, Diamantis Panagiotopoulos, and Gerhard Plath. 2010. Die Inseln der Winde: Die experimentelle Archäologie lässt Minos' Flotte wieder segeln. Ruperto Carola (Ruprecht-Karls-Universität Heidleberg) 2: 4-12.

Guttandin, Thomas, Diamantis Panagiotopoulos, Hermann Pflug, and Gerhard Plath. 2011. Inseln der Winde: Die Maritime Kultur der bronzezeitlichen Ägäis. Heidelberg: Institut für Klassische Archäologie der Universität Heidelberg.

Hammacher, Abraham Marie. 1985. René Magritte. Translated by James Brockway. New York: Harry N. Abrams, Inc.

Herdendorf, Charles E., Tommy Thompson, and Robert D. Evans. 1995. Science on a Deep-Ocean Shipwreck. The Ohio Journal of Science 95: 4-224.

Hocker, Frederick M. 1998a. Appendix: Did Hatshepsut's Punt Ships Have Keels? In Shelley Wachsmann, Seagoing Ships and Seamanship in the Bronze Age Levant. College Station and London: Texas A\&M University Press and Chatham Press, pp. 245-46.

Hocker, Frederick M. 1998b. Glossary of Nautical Terms. In Shelley Wachsmann, Seagoing Ships and Seamanship in the Bronze Age Levant. College Station: Texas A\&M University Press, London: Chatham Press, pp. 377-81.

Hoffmeier, James K. 2018. A Possible Location in Northwest Sinai for the Sea and Land Battles between the Sea Peoples and Ramesses III. Bulletin of the American Schools of Oriental Research 380: 1-25. [CrossRef]

Hornell, James. 1938a. Boat Oculi Survivals: Additional Records. Journal of the Royal Anthropological Institute of Great Britain and Ireland 68: 339-48. [CrossRef]

Hornell, James. 1938b. Boat Processions in Egypt. Man 38: 145-46, pls. I-J. [CrossRef]

Hornell, James. 1943. The Prow of the Ship: Sanctuary of the Tutelary Deity. Man 43: 121-28, pl. B. [CrossRef]

Hornell, James. 1970. Water Transport: Origins and Early Evolution. Reprint 1946. Newport Abbot: David \& Charles.

Ingholt, Harald. 1940. Rapport Préliminaire sur sept Campagnes de Fouilles à Hama en Syrie (1932-1938). Copenhagen: E. Munksgaard.

Jensen, Robin M. 2007. Early Christian Images and Exegesis. In Picturing the Bible: The Earliest Christian Art. Edited by Jeffrey Spier. New Haven: Yale University Press, pp. 65-85.

Johnston, Paul F. 1982. Bronze Age Cycladic Ships: An Overview. In Temple University Aegean Symposium 7. Paper presented at the Symposium Trade and Travel in the Cyclades during the Bronze Age, Department of Art History, Temple University, Philadelphia, PA, USA, March 5; pp. 1-8.

Johnstone, Paul. 1973. Stern First in the Stone Age? International Journal of Nautical Archaeology 2: 3-11. [CrossRef] Jones, Dilwyn. 1990. Model Boats from the Tomb of Tut'Ankhamūn. Tut'ankhamūn's Tomb Series 9; Oxford: Griffith Institute.

Kahneman, Daniel. 2011. Thinking, Fast and Slow. New York: Farrar, Straus and Giroux.

Karageorghis, Vassos, and Jean Des Gagniers. 1974. La céramique chypriote de style figuré. Âge du fer (1050-500 Av. J.-C.): Illustrations et Descriptions des Vases. Rome: Edizioni dell'Ateneo.

Kessler, Herbert L. 2007. The Word Made Flesh in Early Decorated Bibles. In Picturing the Bible: The Earliest Christian Art. Edited by J. Spier. New Haven: Yale University Press, pp. 141-68.

Kirk, Geoffrey Stephen. 1949. Ships on Geometric Vases. Annual of the British School at Athens 44: 93-153, pls. 38-40. [CrossRef]

Kitchen, Kenneth A. 1971. Punt and How to Get There. Orientalia 40: 184-207.

Klein, Reven Chaim. 2016. A Tale of Two Arks. Ohr Somayach. September 24. Available online: https://ohr.edu/7030 (accessed on 12 July 2019).

Kloner, Amos, and Shelley Wachsmann. 1978. A Ship Graffito from Khirbet Rafi. International Journal of Nautical Archaeology 7: 227-32. [CrossRef]

Kohlmeyer, Jan. 1969. Deterioration of Wood by Marine Fungi in the Deep Sea. In Symposium on Materials Performance and the Deep Sea. (1969). Materials Performance and the Deep Sea. Philadelphia: American Society for Testing and Materials, pp. 20-30. 
Korrés, George S. 1989. Representation of a Late Mycenaean Ship on the Pyxis from Tragana, Pylos. In Tropis, Paper presented at the First International Symposium on Ship Construction in Antiquity, Piraeus, August 30-September 1. Edited by Harry Tzalas. Athens: Hellenic Institute for the Preservation of Nautical Tradition, vol. I, pp. 177-202, 199, (In Greek with English summary).

Kristiansen, Kristian. 2019. Representations of Representations: Rock Art, Miniatures and Models. In Tidens landskap: En vänbok till Anders Andrén. Edited by Cecilia Ljung, Anna Andreassen Sjogren, Ingrid Berg, Elin Engstrom, Ann-Mari Ha, Hans Stenholm, Kristina Jonsson, Alison Klevnas, Linda Qvistrom and Torun Zachrisson. Lund: Nordic Academic Press, pp. 65-67.

Landström, Bjorn. 1970. Ships of the Pharaohs. Garden City: Doubleday \& Company, Inc.

Legrain, George. 1917. Le logement et transport des barques sacrées et des statues des dieux dans quelques temples égyptiens. Bulletin de L'institut Français D'archéologie Orientale 13: 1-76, pls. I-VII.

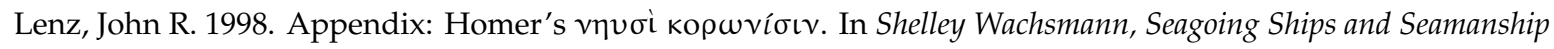
in the Bronze Age Levant. College Station and London: Texas A\&M University Press and Chatham Press, pp. 199-200.

Long, Charlotte R. 1974. The Ayia Triadha Sarcophagus: A Study of Late Minoan and Mycenaean Funerary Practices and Reliefs. Studies in Mediterranean Archaeology 41. Göteborg: P. Åstrom.

Magness, Jodi, Shua Kisilevitz, Matthew Grey, Dennis Mizzi, Daniel Schindler, Martin Wells, Karen Britt, Raanan Boustan, Shana O'Connell, Emily Hubbard, and et al. 2018. The Huqoq Excavation Project: 2014-2017 Interim Report. Bulletin of the American Schools of Oriental Research 380: 61-131. [CrossRef]

Magness, Jodi, Shua Kislilevitz, Matthew Grey, Dennis Mizzi, Karen Britt, and Raanan Boustan. 2019. Inside the Huqoq Synagogue. Biblical Archaeology Review 45: 24-38.

Manning, S. W. 2010. Chronology and Terminology. In The Oxford Handbook of the Bronze Age Aegean (ca. 3000-1000 BC). Edited by Eric H. Cline. Oxford: Oxford University Press, pp. 11-28.

Marinatos, Spyridon. 1933. La marine créto-mycénienne. Bulletin de Correspondance Hellénique 57: 170-235, pls. XIII-XVII. [CrossRef]

Marinatos, Spyridon. 1974. Excavations at Thera. (1972 Season), Text and Plates. Athens: Bibliotheke tes en Athenais Archaeiologikes Etaireias, vol. VI.

Mark, Samuel. 2005. Homeric Seafaring. College Station: Texas A\&M Press.

Mark, Samuel. 2017. The Depiction in the Tomb of Nebamun: The Earliest Egyptian Ship without a Hogging Truss. Journal of Ancient Egyptian Interconnections 16: 68-86.

Martin, Geoffrey Thorndike. 1991. The Hidden Tombs of Memphis: New Discoveries from the Time of Tutankhamun and Ramses the Great. London: Thames and Hudson.

Mazar, Amihai. 1990. Archaeology of the Land of the Bible: 10,000-586 B.C.E. New York: Doubleday.

Mazar, Amihai. 1992. The Iron Age I. In The Archaeology of Ancient Israel. Edited by A. Ben-Tor. West Hanover: Yale University Press and The Open University of Israel, pp. 258-301.

Meiberg, Linda Gail. 2011. Figural Motifs on Philistine Pottery and Their Connections to the Aegean World, Cyprus and Coastal Anatolia. Ph.D. dissertation, University of Pennsylvania, Philadelphia, PA, USA.

Merriman, Ann. 2011. Egyptian Watercraft Models from the Predynastic to Third Intermediate Periods. Oxford: Archaeopress.

Miriam Webster s.v. Occam's Razor. n.d. Available online: https://www.merriam-webster.com/dictionary/Occam\% $27 \mathrm{~s} \% 20$ razor (accessed on 12 July 2019).

Monroe, Christopher Mountfort. 2009. Scales of Fate: Trade, Tradition, and Transformation in the Eastern Mediterranean ca. 1350-1175 BCE. Münster: Ugarit-Verlag.

Morgan, Lyvia. 1988. The Miniature Wall Paintings of Thera: A Study in Aegean Culture and Iconography. New York: Cambridge University Press.

Morrison, John Sinclair, and R. T. Williams. 1968. Greek Oared Ships: 900-322 B.C. Cambridge: Cambridge University Press.

Mountjoy, Penelope A. 2005. Mycenaean Connections with the Near East in LH IIIC: Ships and Sea Peoples. Emporia: Aegeans in the Central and Eastern Mediterranean. Paper presented at the 10th International Aegean Conference/10e Rencontre égéenne internationale, Athens Italian School of Archaeology, Athina, Athens, April 14-18; Edited by Robert Laffineur and E. Greco. Liège and Austin: University of Liège Histoire de l'Art et Archéologie de la Grèce Antique and University of Austin Program in Aegean Scripts and Prehistory, pp. 423-27, pls. XCV-XCVIII. 
Mountjoy, Penelope A. 2006. Mycenaean Pictorial Pottery from Anatolia in the Transitional LH IIIB2-LH IIIC Early and the LH IIIC Phases. In Pictorial Pursuits: Figurative Painting on Mycenaean and Geometric Pottery, Papers from the Two Seminars at the Swedish Institute in 1999 and 2001. Edited by E. Rystedt and B. Wells. Stockholm: Svenska Institutet i Athen, pp. 107-21.

Mountjoy, Penelope Anne. 2011. A Bronze Age Ship from Ashkelon with Particular Reference to the Bronze Age Ship from Bademgediği Tepe. American Journal of Archaeology 115: 483-88. [CrossRef]

Muckelroy, Keith. 1978. Maritime Archaeology. London: Cambridge University Press.

Müller, W. Max. 1904. Neue Darstellungen “mykenischer" Gesandter und phönizischer Schiffe in altägyptischen Wandgemälden. Mitteilungen der Vorderasiatischen Gesellschaft 9: 113-80, Tafs. 1-4.

Muraoka, T. 2009. A Greek-English Lexicon of the Septuagint. Louvain, Paris and Walpole: Peeters.

Naville, Edouard. 1898. The Temple of Deir el Bahri: End of the Northern half and Southern Half of the Middle Platform. London: Egypt Exploration Fund, vol. III.

Nelson, Harold H. 1929. The Epigraphic Survey of the Great Temple of Medinet Habu (Seasons 1924-1925 to 1927-1928). Medinet Habu 1924-1928. Oriental Institute Communications 5: 1-36.

Nelson, Harold H. 1943. The Naval Battle Pictured at Medinet Habu. Journal of Near Eastern Studies 2: 40-45. [CrossRef]

Nowak, Troy Joseph. 1999. A Marble Ophthalmos from Tektaș Burnu. INA Quarterly 26: 10-11.

Nowak, Troy Joseph. 2001. A Preliminary Report on Ophthalmoi from the Tektas Burnu Shipwreck. International Journal of Nautical Archaeology 30: 86-94. [CrossRef]

Nowak, Troy Joseph. 2006. Archaeological Evidence for Ship Eyes: An Analysis of their Form and Function. Master's thesis, Texas A\&M University, College Station, TX, USA.

Onassoglou, Artemis. 1985. Die > Talismanischen< Siegel. Berlin: Gebr. Mann Verlag.

Öniz, Hakan. 2019. A New Bronze Age Shipwreck with Ingots in the West of Antalya-Preliminary Results. Palestine Exploration Quarterly 151: 3-14. [CrossRef]

Papathanassoglou, D. A., and Ch. A. Georgouli. 2009. The 'Frying Pans' of the Early Bronze Age Aegean: An Experimental Approach to Their Possible Use as Liquid Mirrors. Archaeometry 51: 658-671. [CrossRef]

Peck, William H. 1978. Egyptian Drawing. New York: E.P. Dutton.

Pedersen, Ralph Kenneth. 2005. Was Noah's Ark a Sewn Boat? Biblical Archaeology Review 31: 18-23, 55-56.

Pedersen, Ralph Kenneth. 2003. The Boatbuilding Sequence in the Gilgamesh Epic and the Sewn Boat Relation. Ph.D. dissertation, Texas A\&M University, College Station, TX, USA.

Porter, Bertha, and Rosalind Louisa Beaufort Moss. 1981. Topographical Bibliography of Ancient Egyptian Hieroglyphic Texts, Reliefs, and Paintings III: Memphis; Part 2. Saqqâra to Dahshûr, 2nd ed. Revised and Augmented by Jaromír Málek. Oxford: Griffith Institute, Ashmolean Museum.

Pritchard, James B. 1951. Syrians as Pictured in the Paintings of the Theban Tombs. Bulletin of the American Schools of Oriental Research 122: 36-41. [CrossRef]

Pulak, Cemal Mustafa. 1992. The Shipwreck at Ulu Burun, Turkey: 1992 Excavation Season. INA Quarterly 19: 4-11, 21.

Pulak, Cemal. 1995. Das Shiffswrack von Uluburun. In Poseidons Reich: Archäologie unter Wasser. Zaberns Bildbände zur Archäologie 23. Mainz: P. von Zabern, pp. 43-58.

Pulak, Cemal. 2008. The Uluburun Shipwreck and Late Bronze Age Trade. In Beyond Babylon: Art, Trade, and Diplomacy in the Second Millennium B.C.. Edited by Joan Aruz, Kim Benzel and Jean M. Evans. New York: Metropolitan Museum of Art, pp. 288-305, artifact catalogue, pp. 306-10, 313-21, 324-33, 336-48, 350-58, 366-70, 372-78, 382-85.

Rainey, Anson Frank. 1963. A Canaanite at Ugarit. Israel Exploration Journal 13: 43-5.

Rainey, Anson Frank. 1967. A Social Structure of Ugarit. Jerusalem: Mosad Byalik. (In Hebrew)

Rainey, Anson Frank. 1996. Who Is a Canaanite? A Review of the Textual Evidence. Bulletin of the American Schools of Oriental Research 304: 1-15. [CrossRef]

Rainey, Anson Frank, and R. Steven Notley. 2006. The Sacred Bridge: Carta's Atlas of the Biblical World. Jerusalem: Carta.

Reich, Ronny. 1991. A Note on the Roman Mosaic at Magdala on the Sea of Galilee. Liber Annuus 41: 455-58, pls. 53-54.

Reisner, George Andrew. 1913. Models of Ships and Boats. Cairo: Institut Français d'Archéologie Orientale. 
Renfrew, Colin. 1967. Cycladic Metallurgy and the Aegean Early Bronze Age. American Journal of Archaeology 71 : 1-20, pls. 1-10. [CrossRef]

Rieth, Eric. 2016. Navires et Construction Navale au Moyen Âge: Archéologie de la Baltique à la Méditerranée. Paris: Picard.

Riis, Paul Jørgen. 1948. Hama: Fouilles et recherches 1931-1938: Les Cimetières à Crémation. Copenhagen: Gyldendakske Boghandel, Nordisk Forlag, vol. II: 3.

Rowe, Alan. 1936. Addendum A: Axe-Head of the Royal Boat-Crew of Cheops (or Sahew-Rā [?]). In A Catalogue of Egyptian Scarabs, Scaraboids, Seals and Amulets in the Palestine Archaeological Museum. Cairo: 1'Institut Français d'Archéologie Orientale, pp. 283-88.

Säve-Söderbergh, Torgny. 1946. The Navy of the Eighteenth Dynasty. Uppsala: Lundequistska Bokhandeln.

Säve-Söderbergh, Torgny. 1957. Four Eighteenth Dynasty Tombs. Oxford: Oxford University Press.

Schäfer, Heinrich. 1974. Principles of Egyptian Art. Translated by John Baines. Oxford: Clarendon Press.

Schneider, Hans D. 1993. The Rediscovery of Iniuia. Egyptian Archaeology 3: 3-5.

Shaw, Maria C. 1982. Ship Cabins of the Bronze Age Aegean. International Journal of Nautical Archaeology 11: 53-58. [CrossRef]

Shirley, J. J. 2007. The Life and Career of Nebamun, the Physician of the King in Thebes. In The Archaeology and Art of Ancient Egypt: Essays in Honor of David B. O'Connor. Annales du service des antiquités de l'Égypte. Edited by Zahi A. Hawass and Janet Richards. Cairo: Conseil suprême des antiquités de de l'Égypte, pp. 381-401. Sylvester, David. 1992. Magritte: The Silence of the World. New York: Menil Foundation, Harry N. Abrams, Inc. Sjöquist, Erik. 1940. Problems of the Late Cypriote Bronze Age. Stockholm: Swedish Cyprus Expedition. Spier, Jeffrey, ed. 2007a. Picturing the Bible: The Earliest Christian Art. New Haven: Yale University Press.

Spier, Jeffrey, ed. 2007b. The Earliest Christian Art: From Personal Salvation to Imperial Power. In Picturing the Bible: The Earliest Christian Art. Spier, Jeffrey, ed. New Haven: Yale University Press, pp. 1-23.

Stager, Lawrence E., and Penelope Anne Mountjoy. 2007. A Pictorial Krater from Philistine Ashkelon. In Up to the Gates of Ekron: Essays on the Archaeology and History of the Eastern Mediterranean in Honor of Seymour Gitin. Edited by Sidnie White Crawford, Amnon Ben-Tor, Amihai Mazar, William G. Dever and Joseph Aviram. Jerusalem: W.F. Albright Institute of Archaeological Research and Israel Exploration Society, pp. 50-61.

Steffy, John Richard. 1985. The Herculaneum Boat: Preliminary Notes on Hull Details. American Journal of Archaeology 89: 519-21. [CrossRef]

Steffy, John Richard. 1990. The Boat: A Preliminary Study of Its Construction. In The Excavations of an Ancient Boat in the Sea of Galilee (Lake Kinneret). Atiqot 19. Edited by Shelley Wachsmann. Jerusalem: Israel Antiquities Authority, pp. 29-47.

Steffy, John Richard. 1994. Wooden Ship Building and the Interpretation of Shipwrecks. College Station: Texas A\&M Press.

Steffy, J. Richard, and Shelley Wachsmann. 1990. The Midgal Boat Mosaic. In The Excavations of an Ancient Boat from the Sea of Galilee (Lake Kinneret). Edited by Shelley Wachsmann. Jerusalem: Israel Antiquities Authority, pp. 115-18.

Stephens, Michael Allen. 2012. A Categorisation and Examination of Egyptian Ships and Boats from the Rise of the Old to the End of the Middle Kingdoms. BAR International Series 2358; Oxford: Archaeopress.

Strasser, Thomas F., Eleni Panagopoulou, Curtis N. Runnels, Priscilla M. Murray, Nicholas Thompson, Panayiotis Karkanas, Floyd W. McCoy, and Karl W. Wegmann. 2010. Stone Age Seafaring in the Mediterranean: Evidence from the Plakias Region for Lower Paleolithic and Mesolithic Habitation of Crete. Hesperia 79: 145-90. [CrossRef]

Talgam, Rina. 2014. Mosaics of Faith: Floors of Pagans, Jews, Samaritans, Christians, and Muslims in the Holy Land. Jerusalem: Yad Izhak Ben-Zvi, University Park: Pennsylvania State University Press.

Torczyner, Harry. 1979. Magritte: The True Art of Painting. New York: Abradale Press and Harry N. Abrams, Inc. Thurneyssen, Jacques. 1979. Artists Mistakes. A Reply. International Journal of Nautical Archaeology 8: 254. [CrossRef]

Trebilco, Peter R. 1991. Jewish Communities in Asia Minor. Cambridge and New York: Cambridge University Press. Tversky, Amos, and Daniel Kahneman. 1974. Judgment under Uncertainty: Heuristics and Biases. Science 185: 1124-31. [CrossRef] 
Tzalas, Harry. 1990. Kyrenia II in the Fresco of Pedoula Church, Cyprus. A Comparison with Ancient Ship Iconography. In Tropis, Paper presented at the Second International Symposium on Ship Construction in Antiquity, Delphi, Greece, 27-29 August 1990. Edited by Harry Tzalas. Athens: Hellenic Institute for the Preservation of Nautical Tradition, vol. II, pp. 323-27.

Van Effenterre, M. 1978. Cretan Ships on Seal-Stones: Some Observations. In Thera and the Aegean World, Paper presented at the Second International Scientific Congress, Santorini, Greece, August. Edited by Christos Doumas. London: Thera and the Aegean World, vol. I, pp. 593-97.

Vinson, Steve M. 1993. The Earliest Representations of Brailed Sails. Journal of the American Research Center in Egypt 30: 133-50. [CrossRef]

Von Bissing, Friedrich Wilhelm. 1913. Die Kultur des alten Ägyptens. Leipzig: Quelle \& Meyer.

Wachsmann, Shelley. 1980. The Thera Waterborne Procession Reconsidered. International Journal of Nautical Archaeology 9: 287-95. [CrossRef]

Wachsmann, Shelley. 1981. The Ships of the Sea Peoples. International Journal of Nautical Archaeology 10: 187-220. [CrossRef]

Wachsmann, Shelley. 1982. The Ships of the Sea Peoples (IJNA 10.3: 187-220): Additional Notes. International Journal of Nautical Archaeology 11: 297-304. [CrossRef]

Wachsmann, Shelley. 1986. Is Cyprus Ancient Alashiya? New Evidence from an Egyptian Tablet. Biblical Archaeologist 49: 37-40. [CrossRef]

Wachsmann, Shelley. 1987. Aegeans in the Theban Tombs. Orientalia Lovaniensia Analecta 20. Leuven: Uitgeverij Peters.

Wachsmann, Shelley, ed. 1990. The Excavations of an Ancient Boat from the Sea of Galilee (Lake Kinneret). Atiqot 19. Jerusalem: Israel Antiquities Authority.

Wachsmann, Shelley. 1995. Paddled and Oared Ships Before the Iron Age. In The Age of the Galley: Mediterranean Oared Vessels since Pre-Classical Times. Conway's History of the Ship. Edited by Robert Gardiner and John Morrison. London: Naval Institute Press, pp. 10-35.

Wachsmann, Shelley. 1996. Bird-Head Devices on Mediterranean Ships. In Tropis, Paper presented at the Fourth International Symposium on Ship Construction in Antiquity, Athens, Greece, August 28-31. Edited by Harry Tzalas. Athens: Hellenic Institute for the Preservation of Nautical Tradition, vol. IV, pp. 539-72.

Wachsmann, Shelley. 1998. Seagoing Ships and Seamanship in the Bronze Age Levant. College Station and London: Texas A\&M University Press and Chatham Press.

Wachsmann, Shelley. 2002a. The Moulid of Abu el Haggag: A Contemporary Boat Festival in Egypt. In Tropis, Paper presented at the 7th International Symposium on Ship Construction in Antiquity, Lamia, Greece, August 28-30. Edited by Harry Tzalas. Athens: Hellenic Institute for the Preservation of Ship Construction in Antiquity, vol. VII: II, pp. 821-35.

Wachsmann, Shelley. 2002b. Sailing into Egypt's Past: Does a Celebration of Luxor's Patron Saint Echo Ancient Pharaonic Traditions? Archaeology 55: 36-39.

Wachsmann, Shelley. 2007-2008. Deep Submergence Archaeology: The Final Frontier. Skyllis (Deutsche Gesellschaft zur Förderung der Unterwasserarchäeologie e.V.) 8: 130-54.

Wachsmann, Shelley. 2009. The Sea of Galilee Boat, 3rd ed. College Station: Texas A\&M University Press.

Wachsmann, Shelley. 2011a. Deep-Submergence Archaeology. In The Oxford Handbook of Maritime Archaeology. Edited by Alexis Catsambis, Ben Ford and Donny L. Hamilton. New York: Oxford University Press, pp. 202-31.

Wachsmann, Shelley. 2011b. Which Way Forward? On the Directionality of Minoan/Cycladic Ships. Skyllis (Deutsche Gesellschaft zur Förderung der Unterwasserarchäeologie e.V.) 11: 12-18.

Wachsmann, Shelley. 2012. Panathenaic Ships: The Iconographic Evidence. Hesperia 81: 237-66. [CrossRef]

Wachsmann, Shelley. 2013. The Gurob Ship-Cart Model and Its Mediterranean Context. College Station: Texas A\&M University Press.

Wachsmann, Shelley. 2015. Understanding the Boat from the Time of Jesus: Galilean Seafaring. Jerusalem: Carta. Wachsmann, Shelley. In preparation. A Ship Depicted on a Funerary Urn from Hama, Syria, Reconsidered.

Wedde, Michael. 1999. War at Sea: The Mycenaean and Iron Age Oared Galley. In Polemos: Le contexte guerrier en Égée à l'Age du Bronze, Paper presented at the Actes de la $7^{e}$ Recontre Égéene Internationale, Université de Liège, Liège, Belgium, Avril 14-17. Edited by Robert Laffineur. Liège: Univerité de Liège and the University of Texas at Austin, vol. II, pp. 465-76, pls. LXXVII-XCII. 
Wedde, Michael. 2000. Towards a Hermeneutics of Aegean Bronze Age Ship Imagery. Mannheim and Möhnesee: Bibliopolis.

Wedde, Michael. 2002. Birdshead Revisited: The Bow Morphology of the Early Greek Galley. In Tropis, Paper presented at the 7th International Symposium on Ship Construction in Antiquity, Lamia, Greece, August 28-30. Edited by Harry Tzalas. Athens: Hellenic Institute for the Preservation of Ship Construction in Antiquity, vol. VII: II, pp. 837-56.

Wente, Edward Frank, Jr. 2003. The Report of Wenamun. In The Literature of Ancient Egypt: An Anthology of Stories, Instructions, and Poetry. Edited by William Kelley Simpson. Third Edition. New Haven and London: Yale University Press, pp. 116-24.

Wessel, C. J. 1969. The Information Background in the Field of Biological Deterioration of Nonmetallic Materials. In Materials Performance and the Deep Sea, Paper presented at the Seventy-first Annual Meeting, American Society for Testing and Materials, San Francisco, CA, USA, June 23-29. ASTM Special Technical Publication 445. Philadelphia: American Society for Testing and Materials, pp. 131-41.

Whitewright, Julian. 2018. Sailing and Sailing Rigs in the Ancient Mediterranean: Implications of Continuity, Variation and Change in Propulsion Technology. International Journal of Nautical Archaeology 47: 28-44. [CrossRef]

Wreszinski, Walter. 1988. Atlas zur Altaegyptischen Kulturgeschichte. Genève: Slatkine Reprints, vol. II.

Yasur-Landau, Asaf. 2010. On Birds and Dragons: A Note on the Sea Peoples and Mycenaean Ships. In Pax Hethitica: Studies on the Hittites and Their Neighbours in Honor of Itamar Singer. Edited by Yoram Cohen, Amir Gilan and Jared L. Millers. Wiesbaden: Harrassowitz, pp. 399-410.

(C) 2019 by the author. Licensee MDPI, Basel, Switzerland. This article is an open access article distributed under the terms and conditions of the Creative Commons Attribution (CC BY) license (http://creativecommons.org/licenses/by/4.0/). 